\title{
11. HYDROTHERMAL DEPOSITS OF THE GALAPAGOS RIFT ZONE, LEG 70: MINERALOGY AND GEOCHEMISTRY OF MAJOR COMPONENTS ${ }^{1}$
}

\author{
I. M. Varentsov, B. A. Sakharov, V. A. Drits, S. I. Tsipursky, D. Ya. Choporov, and V. A. Aleksandrova, \\ Geological Institute of the USSR Academy of Sciences, Moscow, USSR
}

\begin{abstract}
The hydrothermal deposits that we analyzed from Leg 70 are composed of ferruginous green clays and fragments of manganese-hydroxide crust.

Data from X-ray diffraction, IR-spectroscopy, electron diffraction, and chemical analyses indicate that the hydrothermal green clays are composed of disordered mixed-layer phases of celadonite-nontronite.

Electron diffraction shows that the parameters of the unit cells and the degree of three-dimensional ordering of mixed-layer phases with $80 \%$ celadonite interlayers are very close to Fe-micas of polymorphic modification IMceladonite. In some sections, there is a tendency for the number of celadonite layers to increase with depth.

The manganese-hydroxide crust fragments are predominantly composed of todorokite (buserite).

An essential feature of hydrothermal accumulation is the sharp separation of $\mathrm{Fe}$ and $\mathrm{Mn} . \mathrm{Ba} / \mathrm{Ti}$ and $\mathrm{Ba} / \mathrm{Sr}$ ratios are typical indicators of hydrothermal deposits. Sediments composing the hydrothermal mounds were deposited from moderately heated waters, which had extracted the components from solid basalts in environments where there were considerable gradients of temperature, $\mathrm{eH}$, and $\mathrm{pH}$. The main masses of $\mathrm{Fe}$ and $\mathrm{Mn}$ were deposited in the late Pleistocene. Postsedimentary alteration of deposited hydrothermal sediments led to their slight recrystallization and, in the green clays, to celadonitization.

Further, factor analysis (by Varentsov) of chemical components from these hydrothermal deposits revealed paragenetic assemblages. Green clays corresponding to a definite factor assemblage were formed during the main stage of hydrothermal mineral formation. Manganese hydroxide and associated components were largely accumulated during an early stage and at the end of the main stage.
\end{abstract}

\section{INTRODUCTION}

Hydrothermal deposits and mounds in the area of the Galapagos Spreading Center have attracted attention from scientists for the last decade (e.g., Corliss et al., 1978; Klinkhammer et al., 1977; Lonsdale, 1977; Weiss, 1977). The studies carried out during the Deep Sea Drilling Project (DSDP) Leg 54 elucidated to a considerable extent the nature of hydrothermal deposits and the processes behind their formation (e.g., Donnelly, 1980; Dymond et al., 1980; Hekinian et al., 1980; Hoffert et al., 1980; Humphris and Hallman, 1980; Rateev et al., 1980, Schrader et al., 1980).

Use of the hydraulic piston corer during Leg 70 permitted the retrieval of undisturbed sediment samples, representing continuous stratigraphic records of both hydrothermal mounds and areas removed from zones of hydrothermal activity.

The objectives of our work were to analyze the mineralogical composition of hydrothermal sediments by use of the transmission electron microscope and the scanning electron microscope, X-ray diffraction, and electron diffraction, in order to discover the behavior of various major components, including $\mathrm{Ba}$ and $\mathrm{Sr}$, as well as to estimate the effect of hydrothermal phenomena on pelagic sedimentation processes.

${ }^{1}$ Honnorez, J., Von Herzen, R. P., et al., Init. Repts. DSDP, 70: Washington (U.S. Govt. Printing Office).

\section{MATERIALS AND METHODS}

All available samples were first studied under the light microscope in thin section. We then selected samples for X-ray diffractometric and other physical methods of analysis. X-ray diffraction was carried out using the DRON-2 diffractometer (USSR) with radiation $=\mathrm{CoK}_{\alpha}$ and $\mathrm{CuK}_{\alpha}$ under $35 \mathrm{kV}$ and $20 \mathrm{~mA}$. The rate of scanning was $2 \% \mathrm{~min}$. and for detailed investigation $1 \% \mathrm{~min}$. We obtained diffraction patterns for air-dried samples, some of which were treated with glycerol and ethylene glycol, decalcified, and heated to $550^{\circ} \mathrm{C}$. Precision determinations of spacing $(060)$ of nonoriented specimens were performed at the rate of $1 \% \mathrm{~min}$. Interpreting the nature of mixed-layer clay samples and identifying quantitative relationships between layers and their alternation was done by correlating the experimentally obtained patterns with diffractograms calculated for the corresponding models (Drits and Sakharov, 1976). To determine the structural ordering of the samples, we studied oblique textures (Zvyagin, 1964), using an ER-100 electron diffractometer under accelerating voltage of $100 \mathrm{kV}$. Infrared spectra in the range of $4000-400 \mathrm{~cm}^{-1}$ were taken for all studied samples. Representative samples were studied under the scanning electron microscope (Stereoscan-600, Cambridge) and the transmission electron microscope.

The clay minerals were identified in accordance with the recommendations of the International Committee on Clay Mineral Nomenclature (Bailey et al., 1979; Buckley et al., 1978).

The chemical composition of the sediments was determined at the Chemical Analytical Laboratory of the Geological Institute of the USSR Academy of Sciences, using a plasma spectroanalyzer (ICP) J. Y.-48 (Joben Yvon, France), the weight being $0.1 \mathrm{~g}$. The simultanecusly estimated chemical components are shown in Table 1 (see also Tables 2, 5-9). $\mathrm{H}_{2} \mathrm{O}^{+}, \mathrm{H}_{2} \mathrm{O}^{-}, \mathrm{CO}_{2}, \mathrm{C}_{\text {org }}$, and $\mathrm{FeO}$ were determined for some samples by classical methods of wet analysis to control the total sum. Concentrations of $\mathrm{Cl}, \mathrm{S}$, and several other microelements in some samples were controlled using X-ray fluorescent spectrometry. The instrument (MECCA-1044A, Link Systems, U.K.) had a power dispersion detector. The initial solutions were prepared by a technique close to that described by Walsh (1980). Determinations were con- 
Table 1. Comparison of chemical components in several international geochemical standards (Abbey, 1980) with results of plasma spectroscopy performed at the Geological Institute of the USSR Academy of Sciences.

\begin{tabular}{|c|c|c|c|c|c|c|c|c|c|c|}
\hline \multirow{3}{*}{$\begin{array}{l}\text { Components } \\
\text { (wt. \%) }\end{array}$} & \multirow{2}{*}{\multicolumn{2}{|c|}{$\mathrm{BX}-\mathrm{N}$}} & \multirow{2}{*}{\multicolumn{2}{|c|}{ Mica-Fe }} & \multicolumn{2}{|c|}{ Standards (Abbey, 1980) } & \multirow{2}{*}{\multicolumn{2}{|c|}{ Mica-Mg }} & \multirow{2}{*}{\multicolumn{2}{|c|}{ UB-N }} \\
\hline & & & & & BR & & & & & \\
\hline & Recommended & Determined & Recommended & Determined & Recommended & Determined & Recommended & Determined & Recommended & Determined \\
\hline $\mathrm{SiO}_{2}$ & 7.39 & 7.43 & 34.50 & 35.04 & 38.39 & 38.59 & 38.42 & 38.41 & 39.93 & 39.74 \\
\hline $\mathrm{TiO}_{2}$ & 2.41 & 2.11 & 2.51 & 2.52 & 2.61 & 2.47 & 1.635 & 1.68 & 0.12 & 0.108 \\
\hline $\mathrm{Al}_{2} \mathrm{O}_{3}$ & 54.53 & 54.71 & 19.58 & 19.57 & 10.25 & 10.01 & 15.45 & 14.98 & 2.97 & 2.93 \\
\hline $\mathrm{Fe}_{2} \mathrm{O}_{3}$ & 23.27 & 23.64 & 25.86 & 25.72 & 12.95 & 13.02 & 9.43 & 9.46 & 8.46 & 8.53 \\
\hline $\mathrm{MnO}$ & 0.05 & 0.07 & 0.35 & 0.34 & 0.20 & 0.24 & 0.26 & 0.24 & 0.12 & 0.095 \\
\hline $\mathrm{MgO}$ & 0.11 & 0.06 & 4.61 & 4.86 & 13.35 & 13.58 & 20.46 & 20.85 & 35.99 & 35.88 \\
\hline $\mathrm{CaO}$ & 0.17 & 0.12 & 0.43 & 0.39 & 13.87 & 14.08 & 0.08 & - & 1.185 & 1.15 \\
\hline $\mathrm{Na}_{2} \mathrm{O}$ & 0.06 & 0.05 & 0.301 & 0.28 & 3.07 & 3.07 & 0.12 & 0.18 & 0.1 & 0.105 \\
\hline $\mathrm{K}_{2} \mathrm{O}$ & 0.07 & 0.11 & 8.79 & 8.85 & 1.41 & 1.36 & 10.03 & 9.88 & 0.02 & - \\
\hline $\mathrm{P}_{2} \mathrm{O}_{5}$ & 0.13 & 0.11 & 0.45 & 0.40 & 1.05 & 1.04 & 0.01 & - & 0.03 & 0.04 \\
\hline $\mathrm{BaO}$ & 0.003 & - & 0.02 & - & 0.112 & 0.098 & - & - & - & - \\
\hline
\end{tabular}

\begin{tabular}{|c|c|c|c|c|c|c|c|c|}
\hline \multirow{2}{*}{$\begin{array}{l}\text { Components } \\
\text { (wt.\%) }\end{array}$} & \multicolumn{2}{|c|}{ DR-N } & \multicolumn{2}{|c|}{ GA } & \multicolumn{2}{|c|}{$\mathrm{GH}$} & \multicolumn{2}{|c|}{ DT-N } \\
\hline & Recommended & Determined & Recommended & Determined & Recommended & Determined & Recommended & Determined \\
\hline $\mathrm{SiO}_{2}$ & 52.88 & 53.18 & 69.96 & 70.07 & 75.85 & 75.31 & 36.52 & 36.65 \\
\hline $\mathrm{TiO}_{2}$ & 1.10 & 1.04 & 0.38 & 0.40 & 0.08 & 0.085 & 1.40 & 1.28 \\
\hline $\mathrm{Al}_{2} \mathrm{O}_{3}$ & 17.56 & 17.64 & 14.51 & 15.14 & 12.51 & 12.57 & 59.21 & 59.02 \\
\hline $\mathrm{Fe}_{2} \mathrm{O}_{3}$ & 9.69 & 9.81 & 2.83 & 2.69 & 1.34 & 1.37 & 0.66 & 0.60 \\
\hline $\mathrm{MnO}$ & 0.21 & 0.23 & 0.09 & & 0.05 & 0.051 & 0.008 & 0.004 \\
\hline $\mathrm{MgO}$ & 4.47 & 4.39 & 0.95 & 1.01 & 0.03 & 0.12 & 0.04 & 0.11 \\
\hline $\mathrm{CaO}$ & 7.09 & 7.07 & 2.45 & 2.448 & 0.69 & 0.70 & 0.04 & - \\
\hline $\mathrm{Na}_{2} \mathrm{O}$ & 3.00 & 2.98 & 3.55 & - & 3.85 & - & 0.04 & 0.04 \\
\hline $\mathrm{K}_{2} \mathrm{O}$ & 1.73 & 1.69 & 4.03 & - & 4.76 & - & 0.12 & 0.15 \\
\hline $\mathrm{P}_{2} \mathrm{O}_{5}$ & 0.25 & 0.26 & 0.12 & 0.08 & 0.01 & - & 0.09 & 0.20 \\
\hline $\mathrm{BaO}$ & 0.042 & 0.047 & 0.10 & 0.109 & - & - & - & - \\
\hline
\end{tabular}

trolled by multiple measurement of 22 international standard samples (Abbey, 1980; see Table 1). The computer (PDP 11/03) contained a series of equations which described the relationship between concentrations of measured elements expressed as percentage of oxides. Results were compared to data derived from classical methods of wet chemistry. The deviation from the results of classical analysis did not exceed twice Berenshtein's $\sigma_{r}$ (where $\sigma_{r}$ is a root-mean-square relative deviation for the given range of concentrations) Berenshtein et al., 1979).

It should be emphasized that the hydrothermal deposits and siliceous carbonate sediments have a relatively limited set of mineral components. This allowed us to focus on Hole 509B, from which there was relatively complete recovery of undisturbed core. Data for other holes are provided in relatively brief form.

\section{SITE 509}

\section{Hole 509B}

\section{Mineralogy}

Hole 509B was drilled on top a hydrothermal mound and penetrated 33.4-meter-thick hydrothermal sediments and foraminifer-nannofossil oozes. The lithology is described in the site summary, this volume, as is the mineralogical composition of the sediments. Hole 509B has an abundance of hydrothermal deposits, predominantly green clays and, to a lesser extent, manganese hydroxides in its upper portion (Fig. 1).

Sample 509B-1-2, 65-67 cm. Fragments of manganese-hydroxide crust occur in the interval from 1.24 to 2.70 meters in the form of todorokite (buserite) (see Table 2), relatively weakly crystallized (Frenzel, 1980; Giovanoli, 1980), with a slight admixture of siliceous-clay matter. The patches of todorokite (buserite) have a peculiar nodule-like globular texture with traces of recrystallization (see Plate 1 and Fig. 4).
Sample 509B-2-1, 52-54 cm. This sample is a finely flaked, unevenly crystallized, green olive hydrothermal clay, anisotropic in places, with relatively good crystallization into fine flaked aggregates.

XRD showed (Figs. 2A-C) the main phase of this sample to be a finely dispersed, mixed-layer mineral, namely, mica-smectite, with a slight admixture of calcite and halite. On the diffractogram of the natural sample exists relatively broad basal reflections from the mixed-layer mineral with $d$ spacings equal to $12.0,4.86$, and $3.26 \AA$. After glycerol treatment within the lowangle region, we observed the reflections, with $d=18.2$ and $9.71 \AA$; within large angles we observed the broad reflections, with $d=3.48 \AA$. After glycolation, the reflections were: $d=18.5,9.70$, and $3.35 \AA$. Heating the sample at $550^{\circ} \mathrm{C}$ led to the typical XRD of hydromica or that of dehydrated smectite, with reflections in the regions of $10.0,4.96$, and $3.26 \AA$.

In order to identify the content and alternation pattern of the different layers, diffractograms of the samples treated by glycerol and ethylene glycol were compared with those calculated for corresponding models of mixed-layer structures of mica-smectite (Drits and Sakharov, 1976). Those closest to the experimental patterns were diffractograms calculated for the model in which $W_{m}=0.6, W_{s}=0.4, P_{s s}=0.6$, and $S=1$, where $W_{m}$ and $W_{s}$ are equal to the relative content of mica and smectite layers, respectively; $P_{s s}$ is the transition probability of smectite-layer occurrence (provided that it follows the smectite layer); and $S$ equals "reichweite" (a factor of close ordering). Our interpretation of the coefficient of probability suggests that in this structure, mica and smectite layers tend to segregate. In addition, detailed analysis of the $d$ spacings of the diffractograms 


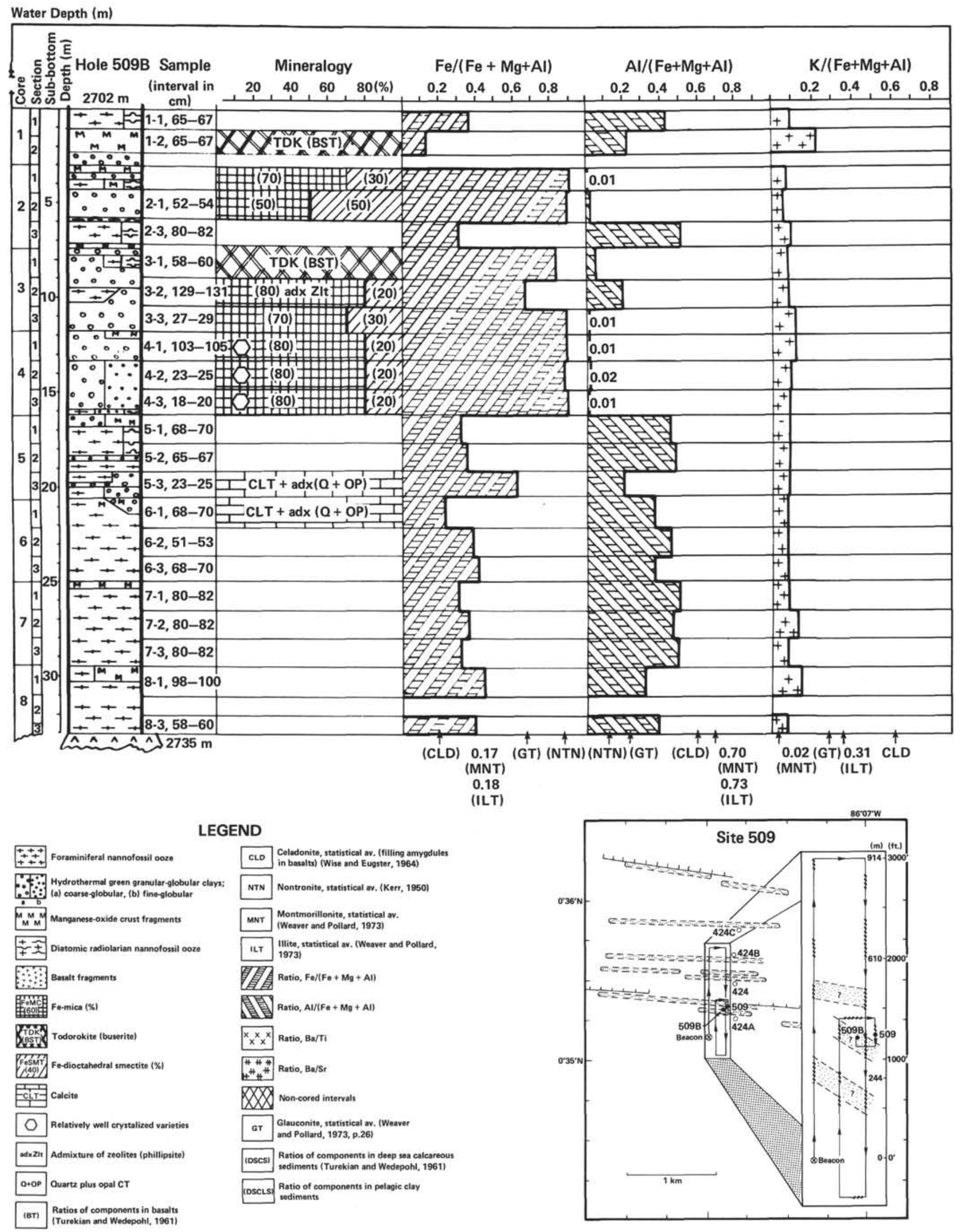

Figure 1. Distribution of mineral components and the ratios $\mathrm{Fe} /(\mathrm{Fe}+\mathrm{Mg}+\mathrm{Al}), \mathrm{Al} /(\mathrm{Al}+\mathrm{Mg}+\mathrm{Fe})$, and $\mathrm{K} /(\mathrm{Fe}+\mathrm{Mg}+\mathrm{Al}), \mathrm{Hole} 509 \mathrm{~B}$. 
Table 2. Chemical composition of upper Cenozoic sediments, Hole 509B.

\begin{tabular}{|c|c|c|c|c|c|c|c|c|c|c|c|c|c|}
\hline No. & $\begin{array}{l}\text { Sample } \\
\text { (interval in } \mathrm{cm} \text { ) }\end{array}$ & $\mathrm{SiO}_{2}$ & $\mathrm{TiO}_{2}$ & $\mathrm{Al}_{2} \mathrm{O}_{3}$ & $\mathrm{Fe}_{2} \mathrm{O}_{3}$ & $\mathrm{MnO}$ & $\begin{array}{l}\mathrm{MgO} \\
\mathrm{tt} \% \text {; air }\end{array}$ & $\begin{array}{l}\mathrm{CaO} \\
\text {-dried) }\end{array}$ & $\mathrm{P}_{2} \mathrm{O}_{5}$ & $\mathrm{Na}_{2} \mathrm{O}$ & $\mathrm{K}_{2} \mathrm{O}$ & $\mathrm{BaO}$ & $\mathrm{SrO}$ \\
\hline 1 & $1-1,65-67$ & 15.61 & 0.10 & 3.05 & 1.95 & 6.90 & 1.35 & 25.78 & 0.09 & 5.07 & 0.50 & 0.259 & 0.105 \\
\hline 2 & $1-2,65-67$ & 1.74 & 0.03 & 1.35 & 0.61 & 61.4 & 3.58 & 1.07 & 0.05 & 2.96 & 0.99 & 0.406 & 0.060 \\
\hline 3 & $2-1,52-54$ & 43.24 & 0.01 & 0.48 & 28.25 & 0.60 & 2.95 & 1.51 & 0.02 & 2.36 & 2.03 & 0.026 & 0.004 \\
\hline 4 & $2-2,57-59$ & 43.86 & 0.02 & 0.58 & 28.76 & 0.12 & 3.13 & 0.35 & 0.00 & 3.00 & 1.48 & 0.065 & 0.005 \\
\hline 5 & $2-3,80-82$ & 15.18 & 0.14 & 3.72 & 1.72 & 0.78 & 1.16 & 34.48 & 0.03 & 3.14 & 0.49 & 0.268 & 0.136 \\
\hline 6 & $3-1,58-60$ & 29.30 & 0.04 & 1.37 & 18.81 & 7.90 & 2.98 & 6.45 & 0.07 & 2.57 & 1.69 & 0.184 & 0.036 \\
\hline 7 & $3-2,129-131$ & 45.07 & 0.28 & 6.67 & 17.62 & 0.32 & 4.35 & 3.21 & 0.26 & 5.76 & 2.07 & 0.603 & 0.037 \\
\hline 8 & $3-3,27-29$ & 46.40 & 0.02 & 0.56 & 28.01 & 0.11 & 3.55 & 0.22 & 0.04 & 2.18 & 3.41 & 0.049 & 0.005 \\
\hline 9 & $4-1,103-105$ & 48.21 & 0.004 & 0.30 & 29.19 & 0.03 & 3.68 & 0.04 & 0.03 & 1.80 & 3.61 & 0.000 & 0.003 \\
\hline 10 & $4-2,23-25$ & 48.42 & 0.02 & 0.59 & 28.22 & 0.04 & 3.79 & 0.00 & 0.001 & 2.78 & 2.83 & 0.029 & 0.003 \\
\hline 11 & $4-3,18-20$ & 44.94 & 0.02 & 0.61 & 30.82 & 0.06 & 3.66 & 0.50 & 0.03 & 2.72 & 2.87 & 0.086 & 0.006 \\
\hline 12 & $5-1,68-70$ & 13.47 & 0.10 & 3.02 & 1.64 & 0.83 & 1.35 & 39.69 & 0.03 & 2.99 & 0.42 & 0.268 & 0.126 \\
\hline 13 & $5-2,65-67$ & 7.99 & 0.08 & 2.47 & 1.41 & 0.85 & 0.86 & 43.16 & 0.05 & 2.22 & 0.30 & 0.289 & 0.153 \\
\hline 14 & $5-3,23-25$ & 15.10 & 0.08 & 2.54 & 5.72 & 1.74 & 1.91 & 33.42 & 0.08 & 2.30 & 0.76 & 0.261 & 0.109 \\
\hline 15 & $6-1,68-70$ & 8.35 & 0.09 & 2.69 & 2.46 & 0.45 & 1.32 & 42.31 & 0.02 & 2.52 & 0.37 & 0.171 & 0.137 \\
\hline 16 & $6-2,51-53$ & 7.91 & 0.15 & 2.76 & 1.77 & 0.39 & 0.90 & 45.11 & 0.06 & 2.11 & 0.31 & 0.176 & 0.152 \\
\hline 17 & $6-3,68-70$ & 8.07 & 0.07 & 2.31 & 2.03 & 0.37 & 1.33 & 41.72 & 0.00 & 2.43 & 0.33 & 0.179 & 0.134 \\
\hline 18 & $7-1,80-82$ & 5.66 & 0.06 & 2.19 & 1.02 & 0.41 & 0.75 & 50.10 & 0.02 & 1.67 & 0.24 & 0.144 & 0.149 \\
\hline 19 & $7-2,80-82$ & 8.52 & 0.08 & 2.65 & 1.50 & 0.27 & 0.83 & 44.93 & 0.05 & 2.05 & 0.40 & 0.190 & 0.136 \\
\hline 20 & $7-3,80-82$ & 7.16 & 0.08 & 2.48 & 1.21 & 0.21 & 0.83 & 47.92 & 0.03 & 2.14 & 0.30 & 0.190 & 0.129 \\
\hline 21 & $8-1,98-100$ & 12.91 & 0.13 & 3.58 & 2.43 & 0.28 & 1.43 & 37.70 & 0.05 & 3.04 & 0.59 & 0.283 & 0.115 \\
\hline 22 & $8-3,58-60$ & 11.52 & 0.18 & 3.27 & 2.58 & 0.26 & 1.58 & 40.97 & 0.05 & 3.17 & 0.45 & 0.252 & 0.118 \\
\hline
\end{tabular}

for glycerinated and dehydrated samples showed that the considered phase is represented by fine dispersed particles which contain less than 20 elementary 2:1 layers. This conclusion is supported by the irregular series of basal reflections, with $d=10.0$ and $3.29 \AA$, which is observed on the diffractogram of the sample heated at $550^{\circ} \mathrm{C}$ (Fig. 2); on the diffractogram of the glycerinetreated sample is a broad reflection with $d=18.2 \AA$ (Drits and Sakharov, 1976).

An interesting feature of the intensities on the diffractogram of the dehydrated sample is the presence of a rather weak reflection, with $d=4.96 \AA$, which may be evidence for a high content of $\mathrm{Fe}$ cations in the octahedrons of the 2:1 layers (Fig. 2).

On the infrared spectra one can observe a broad band of absorption in the region $3530-3550 \mathrm{~cm}^{-1}$, which supports our conclusions concerning the 2:1 layers (Fig. 3).

Sample 509B-2-2, 57-59 cm. This sample is a weakly crystallized and almost isotropic green hydrothermal clay with a distinctly globular, patch-like texture. The size of the globules ranges from $0.007-0.015 \mathrm{~mm}$ up to $0.3 \mathrm{~mm}$.

XRD of this sample (Figs. 2D-F) and comparison with the calculated diffraction patterns, showed that the main component is the finely dispersed, highly ferruginous mixed-layer phase mica-smectite, with $W_{m}: W_{s}=$ $0.5: 0.5$ and $S=0$. Thus, in this sample, the mica and smectite layers are alternating in complete disorder; slight amounts of halite were admixed.

Sample 509B-2-3, 80-82 cm. This sample is composed of ooze (radiolarian, $5 \%$; diatomic, $10 \%$; foraminifer, $20 \%$; nanno-micritic, $60 \%$ ) with a few patches of green globular clay, similar to hydrothermal clay.

Sample 509B-3-1, 58-60 cm. This sample is composed of fragments of manganese-hydroxide crust. The groundmass is manganese hydroxides with colloform-globular texture; the globules are $0.015-0.04 \mathrm{~mm}$ in size, while their aggregates are up to $0.4 \mathrm{~mm}$. There is a slight admixture of siliceous-clay material $(20 \%)$. XRD (Fig. 4B) indicates that the managanese hydroxides are predomi- nantly todorokite (buserite) with an admixture of calcite and traces of residual halite (Table 2, Fig. 4, Plates 2, 3).

Sample 509B-3-2, 129-131 cm. This green to green olive hydrothermal sediment is composed of globules of clay matter $(0.04-0.07 \mathrm{~mm})$ and their aggregates (up to $0.4 \mathrm{~mm}$ ). Crystallized parts have fine flaky patches. In places there are patches composed of pale green clay matter containing aggregates of zeolite and feldspars. XRD (Figs. 2G-I) indicates that it is represented by disordered layers of $\mathrm{Fe}$-mica and $\mathrm{Fe}$-smectite in proportion 80:20, $S=0$, with an admixture of zeolite (phillipsite type), feldspar, and traces of halite.

Sample 509B-3-3, 27-29 cm. This sample is composed of a green hydrothermal clay, with remains of radiolarians and diatoms replaced by clay matter. In the zones of replacement, the clay matter is considerably lighter. As a whole, the clay groundmass is almost not crystallized; it is isotropic, with a weakly expressed globular structure and a few crystals of phillipsite. XRD (Figs. 2J-L) indicates that the clay is represented by disordered mixed layers of Fe-mica and $\mathrm{Fe}$-smectite in the proportion $W_{m}$ : $W_{s}=70: 30, S=0$.

Sample 509B-4-1, 103-105 cm. This is a relatively homogeneous green hydrothermal clay. Observed in polarized light, the groundmass consists of spherulitic aggregates, $0.007-0.04$ up to $0.15 \mathrm{~mm}$ in size. Isometric strain crystals are well developed in some vein-like areas $(0.04 \times 0.02 \mathrm{~mm})$. XRD suggests that it is composed of highly ferruginous mixed-layer phases, with alternating layers of Fe-mica and Fe-smectite in the proportion $W_{m}$ : $W_{s}=80: 10$, and with a slight tendency for similar layers to segregate $\left(P_{s s}=0.3 ; S=1\right)$. The photomicrographs taken under the scanning electron microscope (Plates 4, 6) distinctly show globular structure and distribution of newly formed acicular crystals of $\mathrm{Fe}$-mica.

Sample 509B-4-2, 23-25 cm. This is a green hydrothermal clay with indistinct globular texture; it is almost isotropic in polarized light, with relict biogenic structures ( $20 \%$ diatoms and foraminifers) which have been replaced by clayey matter. In these same replacement 


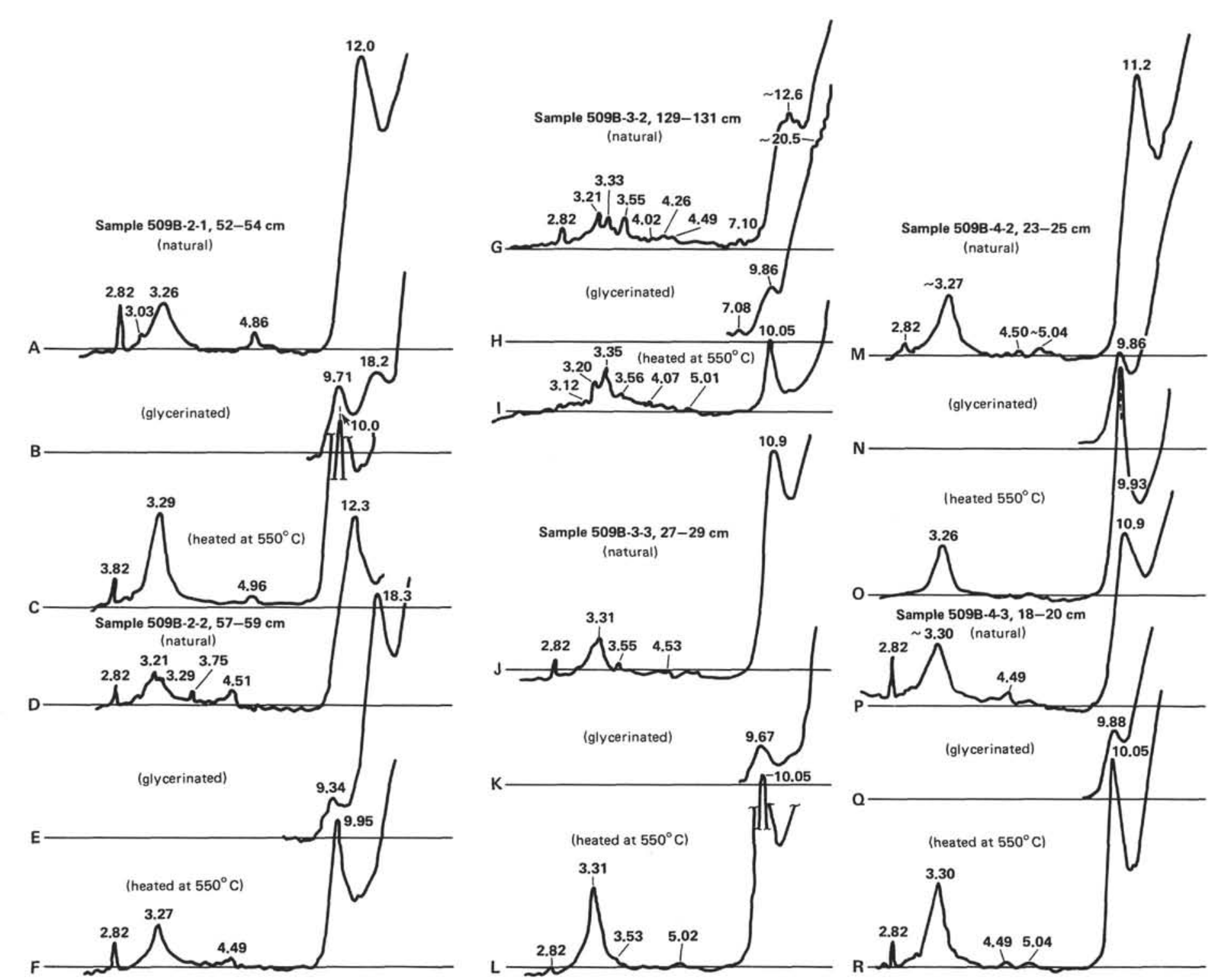

Figure 2. X-ray diffraction patterns (Co-anticathode) of hydrothermal green sediments, Hole 509B. A. Sample 509B-2-1, 52-54 cm, natural; B. same sample treated with glycerol; C. same sample heated at $550^{\circ} \mathrm{C}$. The sample is composed of heterogeneous, disordered, mixed-layer phases of Fe-mica (celadonite) and Fe-dioctahedral smectite (nontronite) (70:30) (Drits and Sakharov, 1976). D. Sample 509B-2-2, 57-59 cm, natural; E. same sample treated with glycerol; F. same sample heated at $550^{\circ} \mathrm{C}$. The sample is composed of disordered, mixed-layer phases of Fe-mica (celadonite) and Fe-dioctahedral smectite (nontronite) (50:50) (Drits and Sakharov, 1976). G. Sample 509B-3-2, 129-131 cm, natural; H. same sample treated with glycerol; I. same sample heated at $550^{\circ} \mathrm{C}$. The sample is composed of heterogeneous mixed-layer phases of Fe-mica (celadonite) and Fe-dioctahedral smectite (nontronite), with small admixtures of phillipsite, plus traces of quartz and feldspar. J. Sample 509B-3-3, 27-29 cm, natural; K. same sample treated with glycerol; L. same sample heated at $550^{\circ} \mathrm{C}$. This sample is composed of heterogeneous mixed-layer phases of Fe-mica (celadonite) and Fe-dioctahedral smectite (70:30) (Drits and Sakharov, 1976). M. Sample 509B-4-2, 23-25 cm, natural; N. same sample treated with glycerol; O. same sample heated at $550^{\circ} \mathrm{C}$. The sample is composed of heterogeneous mixed-layer phases of Fe-mica (celadonite) and Fe-dioctahedral smectite (80:20). P. Sample 509B-4-3, 18-20 $\mathrm{cm}$, natural; Q. same sample treated with glycerol; R. same sample heated at $550^{\circ} \mathrm{C}$. This sample is composed of mixed-layered phases of Fe-mica (celadonite) and Fe-dioctahedral smectite (nontronite) (80:20), with distinct homogeneity. 


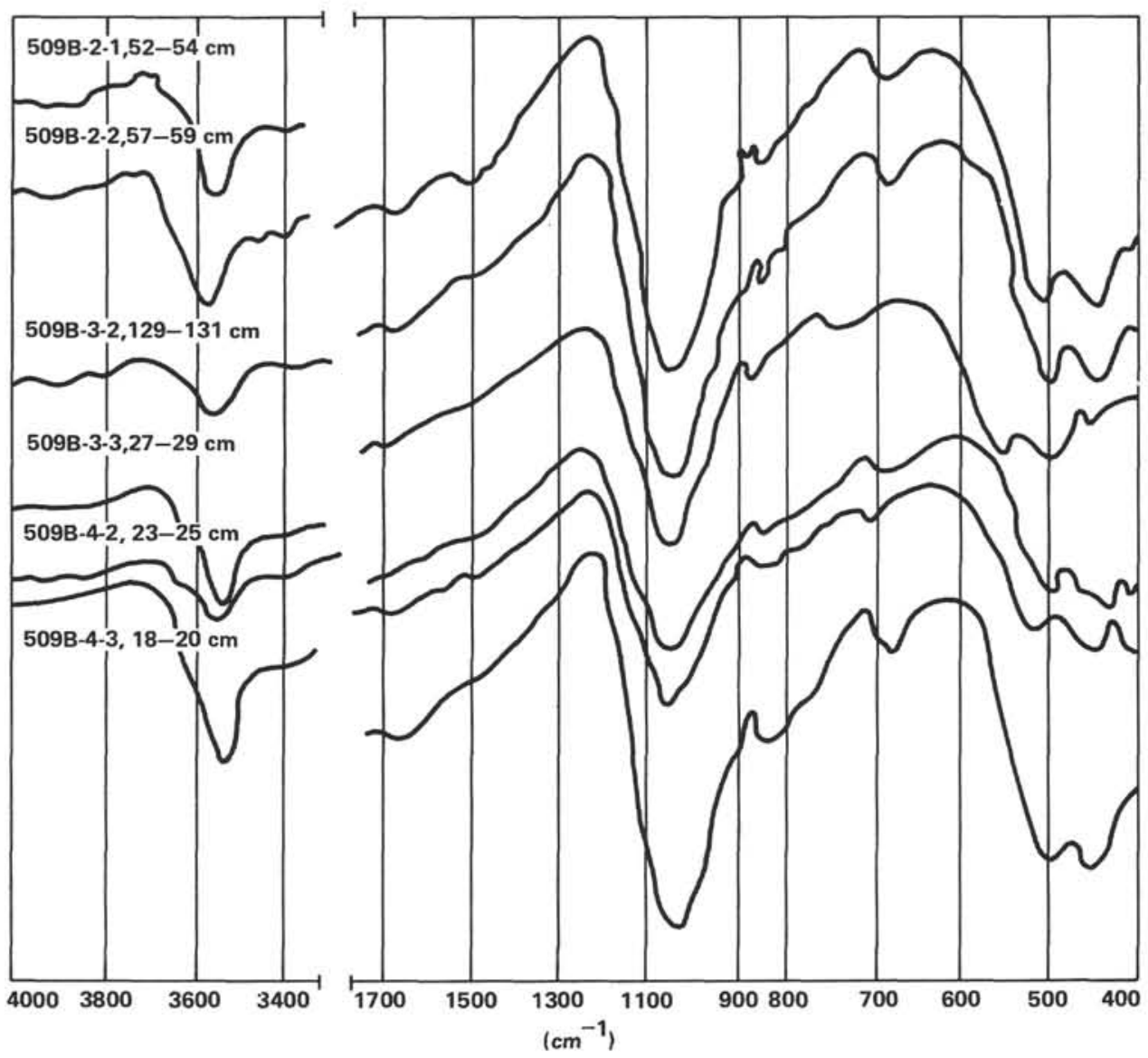

Figure 3. IR-spectra of natural samples of green hydrothermal clays, Hole 509B. (See also Fig. 1.)

Sample 509B-1-2, 65-67

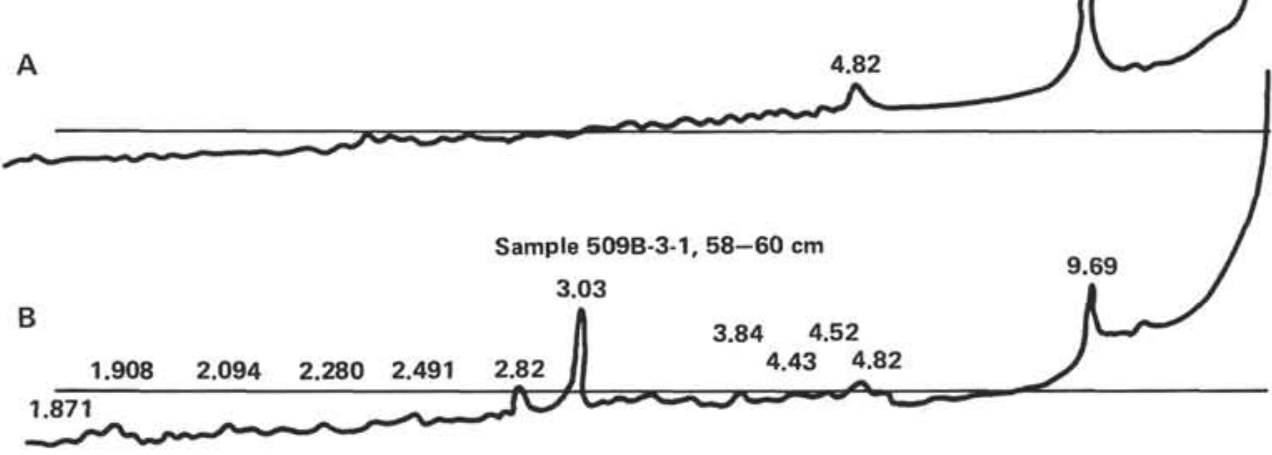

Figure 4. X-ray diffraction patterns (Co-anticathode) of natural samples of crust-like deposits composed of manganese hydroxide, Hole 509B. (See also Fig. 1, Table 2.) A. Sample 509B-1-2, 65-67 cm, represented by weakly recrystallized todorokite (buserite). B. Sample 509B-3-1, 58-60 cm, composed of todorokite (buserite) with a slight admixture of calcite and halite. (See also Fig. 1.)

zones, the recrystallization of clayey matter is relatively high. XRD (Figs. 2M-O) suggests that the sample is rather similar to Sample 509B-4-1, 103-105 cm (Fig. 1).

Sample 509B-4-3, 18-20 cm. This is an olive green hydrothermal clay, very weakly crystallized. In places it has rare spots of goethite patches, the product of rela- tively late-stage alteration. XRD (Figs. 2P-R) indicates that the clay contains mixed layers of Fe-mica and $\mathrm{Fe}-$ smectite in the proportion $W_{m}: W_{s}=80: 20, S=0$. It has a pronounced globular texture with indistinct lamination within a single globule and a definite recrystallization pattern of acicular to fibrous crystallites of Fe-mica 
(Plates 4-6). Traces of calcite, halite, and phillipsite were noted.

Sediments from the deeper intervals down to basaltic basement (see Fig. 1) are represented by foraminifernannofossil-micritic oozes (up to $60 \%$ ), clayey, with rare remains of radiolarians and diatoms; sometimes with spots of hydrothermal green clay matter (Samples 509B$5-1,68-70 \mathrm{~cm}$ and 509B-5-3, 23-25 cm), with fragments of brown basalt glass (Sample 509B-6-2, 51-53 cm; Sample 509B-7-3, 80-82 cm), scattered manganese hydroxides, and to a lesser extent, iron hydroxides (Sample 509B-6-3, 68-70 cm; Sample 509B-7-1, 80-82 cm).

Our observations on the mineral composition of green hydrothermal clays were refined by electron diffraction study of oblique textures. Three representative samples from Hole 509B (i.e., Sample 509B-3-3, 27-29 cm, Sample 509B-4-1, 103-105 cm, and Sample 509B-4-3, 18-20 $\mathrm{cm}$ ) were studied. The electron patterns of oblique textures (EOT) showed rather well-resolved spatial reflections ( $\mathrm{hKl}$ ), with index $\mathrm{K}=3 n(201,131)$ on the second ellipse and with $K \neq 3(021,111)$ on the first ellipse. This pattern shows the existence of three-dimensional order in the minerals in vacuum conditions (Fig. 5). The position of the reflections and the distributions of intensities over EOT for all the samples are very close and similar to the distribution of intensities of reflections over EOT of celadonite and glauconite minerals (Zvyagin, 1964). Analyses of geometric patterns and estimation of spatial-reflection intensities permitted us to identify the parameters of unit cells of minerals and to establish that the varieties studied can be considered polymorphic modifications of the mica IM (Table 3).

The fact that the intensity of reflection on the small axis of the 6th ellipse considerably exceeded that on the 7 th ellipse appeared to be common for all EOT (see Fig. 5). This shows that the minerals are highly ferruginous

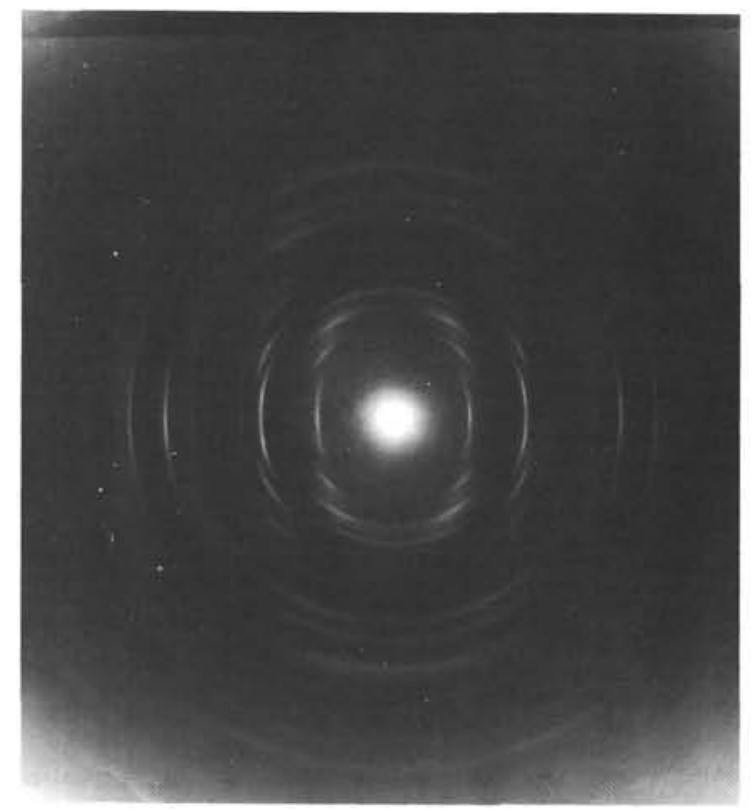

Figure 5. Electron diffraction pattern of oblique texture of green hydrothermal clay, Sample 509B-3-3, 27-29 cm.
Table 3. Parameters of unit cells of samples of monomineral components of green hydrothermal clays, Hole 509B.

\begin{tabular}{llccccc}
\hline No. & $\begin{array}{c}\text { Sample } \\
\text { (interval in cm) }\end{array}$ & $\begin{array}{c}\text { a } \\
(\AA)\end{array}$ & $\begin{array}{c}\text { b } \\
(\AA)\end{array}$ & $\begin{array}{c}\text { c } \\
(\AA)\end{array}$ & $\begin{array}{c}\text { d } \\
\left({ }^{\circ}\right)\end{array}$ & $\begin{array}{c}\text { C. } \sin \beta \\
(\AA)\end{array}$ \\
\hline 1 & $509 \mathrm{~B}-3-3,27-29$ & 5.24 & 9.08 & 10.12 & 100.6 & 9.95 \\
2 & $509 \mathrm{~B}-4-1,103-105$ & 5.24 & 9.08 & 10.15 & 100.4 & 9.98 \\
3 & $509 \mathrm{~B}-4-3,18-20$ & 5.24 & 9.08 & 10.12 & 100.5 & 9.95 \\
\hline
\end{tabular}

(Zvyagin, 1964). In addition, the EOT's of all samples indicate that those reflections with index 022 on the first ellipse are considerably weaker than the corresponding reflections for celadonites and glauconites. This is evidence for a lower concentration of interlayered $\mathrm{K}^{+}$cations in the structures of the minerals studied (Tsipursky et al., 1978). A different background of diffuse scattering (the least of which is found in Sample 509B-3-3, $27-29 \mathrm{~cm}$ [see Fig. 5]) possibly results from different concentrations of defects in the packing of the 2:1 layers. Clay samples with similar mineral composition were recovered from hydrothermal sediments in the Atlantis II basin of the Red Sea (Butuzova et al., 1979).

The data from chemical analysis (Table 2 ) were recalculated for each sample on the average structural formula of the mixed-layer mineral, taking into account the presence of admixtures of calcite and halite.

In Table 4 are given the results of XRD and chemical analysis of the green clay samples: namely, the relative content of mica and smectite layers $\left(W_{m}: W_{s}\right)$; the average structural formula of minerals, recalculated to anionic composition $\mathrm{O}_{10}(\mathrm{OH})_{2}$; the charge of tetrahedral and octahedral sheets; $d(001)$ for natural sample spacings of $d(060)$; and parameter $b$.

All of the samples studied may be divided into two groups on the basis of the relationships between the mica and smectite layers of mixed-layer phases. Those samples confined to the upper group of the section (Samples 509B-2-1, 52-54 cm and 509B-2-2, 57-59 cm) are characterized by a $W_{m}: W_{s}$ ratio ranging from $0.5: 0.5$ to $0.6: 0.4$, whereas in samples from the lower part of the section (Samples 509B-3-3, 27-29 cm; 509B-4-1, 103-105 $\mathrm{cm} ; 509 \mathrm{~B}-4-2,23-25 \mathrm{~cm}$ ) the ratio varies from $0.7: 0.3$ to $0.8: 0.2$. The pronounced increase in the mica component is represented by the fact that downward in the section the decrease of the basal spacings $d(001)$ of the natural samples from 12.3 to $10.7 \AA$ is shown. Along with it, in this direction, the content of $\mathrm{K}^{+}$cations increased from 0.16 to 0.37 (recalculated to the half unit cell), accompanied by a parallel decrease of $\mathrm{Mg}$ contents within interlayered positions. Thus, downward in the section one observes the micatization of the initial clay matter.

In order to determine the nature of the mica phase, it seems appropriate to consider in detail the whole set of crystallochemical and structural characteristics of the samples studied. Worthy of attention is the high ferruginity of all the samples and the absence of $\mathrm{Al}$ from their composition. Table 4 shows that for samples from the upper part of the section the negative charge of the 2:1 layers is approximately equally shared between octa- 
Table 4. Results of X-ray diffraction and crystallochemical study of hydrothermal green clay samples, Hole 509B.

\begin{tabular}{|c|c|c|c|c|c|c|c|c|}
\hline \multirow[b]{2}{*}{ No. } & \multirow{2}{*}{$\begin{array}{c}\text { Sample } \\
\text { (interval in } \mathrm{cm} \text { ) }\end{array}$} & \multirow[b]{2}{*}{$W_{m}: W_{s}$} & \multirow{2}{*}{$\begin{array}{l}\text { Structural Formula } \\
\text { to } \mathrm{O}_{10}(\mathrm{OH})_{2}\end{array}$} & \multicolumn{2}{|c|}{ Charge } & \multirow{2}{*}{$\begin{array}{c}d(001) \\
(\AA)\end{array}$} & \multirow{2}{*}{$\begin{array}{c}d(060) \\
(\AA)\end{array}$} & \multirow{2}{*}{ 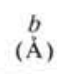 } \\
\hline & & & & Tetrahedron & Octahedron & & & \\
\hline 1 & $2-1,52-54$ & $0.60: 0.40$ & $\left(\mathrm{Si}_{3.81} \mathrm{Al}_{0.05} \mathrm{Fe}_{0.14}^{3+}\right)\left(\mathrm{Fe}_{1.73}^{+} \mathrm{Mg}_{0.27}\right) \mathrm{Mg}_{0.12} \mathrm{~K}_{0.23}$ & 0.19 & 0.27 & 12.0 & 1.5163 & 9.098 \\
\hline 2 & $2-2,57-59$ & $0.50: 0.50$ & $\left(\mathrm{Si}_{3.80} \mathrm{Al}_{0.06} \mathrm{Fe}_{0.14}^{3+}\right)\left(\mathrm{Fe}_{1.72}^{3}{ }^{+} \mathrm{Mg}_{0.28}\right) \mathrm{Mg}_{0.13} \mathrm{~K}_{0.16} \mathrm{Ca}_{0.03}$ & 0.20 & 0.28 & 12.3 & 1.5166 & 9.100 \\
\hline \multicolumn{2}{|c|}{ Average: Nos. 1,2} & $0.55: 0.45$ & $\left(\mathrm{Si}_{3.80} \mathrm{Al}_{0.06} \mathrm{Fe}_{0.14}^{3+}\right)\left(\mathrm{Fe}_{1.73}^{3}{ }^{+} \mathrm{Mg}_{0.27}\right) \mathrm{Mg}_{0.13} \mathrm{~K}_{0.21}$ & 0.20 & 0.27 & - & - & - \\
\hline 3 & $3-3,27-29$ & $0.75: 0.25$ & $\left(\mathrm{Si}_{3.84} \mathrm{Al}_{0.05} \mathrm{Fe}_{0.11}^{3+}\right)\left(\mathrm{Fe}_{1.63}^{3}{ }^{+} \mathrm{Mg}_{0.37}\right) \mathrm{Mg}_{0.07} \mathrm{~K}_{0.36} \mathrm{Ca}_{0.02}$ & 0.16 & 0.37 & 10.9 & 1.5146 & 9.088 \\
\hline 4 & $4-1,104-105$ & $0.80: 0.20$ & $\left(\mathrm{Si}_{3.85} \mathrm{Al}_{0.03} \mathrm{Fe}_{0.12}^{3+}\right)\left(\mathrm{Fe}_{1.63}^{3+} \mathrm{Mg}_{0.37}\right) \mathrm{Mg}_{0.07} \mathrm{~K}_{0.37}$ & 0.15 & 0.37 & 10.7 & 1.5148 & 9.089 \\
\hline 5 & $4-2,23-25$ & $0.70: 0.30$ & $\left(\mathrm{Si}_{3.88} \mathrm{Al}_{0.06} \mathrm{Fe}_{0.06}^{+}\right)\left(\mathrm{Fe}_{1.64}^{3}{ }^{+} \mathrm{Mg}_{0.36}\right) \mathrm{Mg}_{0.09} \mathrm{~K}_{0.29}$ & 0.12 & 0.36 & 11.2 & 1.5144 & 9.086 \\
\hline \multicolumn{2}{|c|}{ Average: Nos. $3,4,5$} & $0.75: 0.25$ & $\left(\mathrm{Si}_{3.86} \mathrm{Al}_{0.05} \mathrm{Fe}_{0.09}^{3+}\right)\left(\mathrm{Fe}_{1.63}^{3+} \mathrm{Mg}_{0.37}\right) \mathrm{Mg}_{0.09} \mathrm{~K}_{0.33}$ & 0.14 & 0.37 & - & - & - \\
\hline \multicolumn{2}{|c|}{$\begin{array}{l}\text { Structural formula } \\
\text { for mica component } \\
\text { (celadonite) }\end{array}$} & $1: 0$ & {$\left[\mathrm{Si}_{3.95}\left(\mathrm{Al}, \mathrm{Fe}^{3+}\right)_{0.05}\right]\left(\mathrm{Fe}_{1}^{3}{ }^{+} .60 \mathrm{Mg}_{0.40}\right) \mathrm{K}_{0.45}$} & 0.05 & 0.40 & - & - & - \\
\hline \multicolumn{2}{|c|}{$\begin{array}{l}\text { Structural formula for } \\
\text { smectite component } \\
\text { (nontronite) }\end{array}$} & $0: 1$ & {$\left[\mathrm{Si}_{3.60}\left(\mathrm{Al}, \mathrm{Fe}^{3+}\right)_{0.40}\right]\left(\mathrm{Fe}_{1.80}^{3+} \mathrm{Mg}_{0.20}\right) \mathrm{Mg}_{0.30}$} & 0.40 & 0.20 & - & - & - \\
\hline
\end{tabular}

hedral and tetrahedral nets; whereas in samples from the lower part of the section, the charge is localized within octahedrons, mainly because of the substitution of $\mathrm{Fe}^{3+}$ for $\mathrm{Mg}$.

One remarkable feature of the mixed-layered minerals we studied is the low degree of substitution within tetrahedrons of $\mathrm{Si}$ (mainly for $\mathrm{Fe}^{3+}$ and, in the lower portion, for $\mathrm{Al}$ ). At the transition from the upper part of the section to the lower part, this value decreased from 0.20 to 0.12 . Along with a decrease of $\mathrm{Fe}^{3+}$ from 1.73 to 1.64 an associated increase of $\mathrm{Mg}$ from 0.27 to 0.37 within octahedrons of 2:1 layers (expressed in formula units) was noted. It is possible to calculate the approximate structural formulas separately for mica and smectite layers (Table 4). Consideration of these formulas shows that the composition of the mica component is similar to that of celadonite because in the tetrahedrons there is practically no substitution of $\mathrm{Si}$ for $\mathrm{Al}$ and $\mathrm{Fe}$, and the whole negative charge of the 2:1 layer is localized within the octahedrons as a consequence of substitution of $\mathrm{Fe}^{3+}$ for $\mathrm{Mg}$. However, these layers are not yet truly celadonite in composition, because their octahedrons contain considerable amounts of $\mathrm{Fe}^{3+}(1.60)$ and the interlayers have lower concentrations of $\mathrm{K}^{+}$cations $(0.45)$. At the same time, the structural formula of the smectite layers is close to that of nontronite, because the total negative charge of the 2:1 layers is caused by the isomorphous substitution of $\mathrm{Fe}^{3+}$ for $\mathrm{Mg}$ within octahedrons, as well as by the considerable content of three valence cations $\left(\mathrm{Fe}^{3+}\right.$ and $\left.\mathrm{Al}\right)$ in tetrahedrons. With respect to these features, the results of precise measurements of $d(060)$ for the samples studied becomes clearer. Table 4 shows that with an increase in the mica component, the spacing $d(060)$ decreased from 1.5166 to 1.5144 . However, the value of this parameter is essentially higher than that of celadonite: $d(060) \leq 1.510 \AA$. This discrepancy is caused by the low content of K cations in the mica layers, the high ferruginization of octahedrons, and the replacement within tetrahedrons of $\mathrm{Si}$, mainly for $\mathrm{Fe}^{3+}$.

It should be emphasized again that the EOT of the samples from the lower part of the section provides evi- dence for the high degree of three-dimensional ordering of 2:1 layers, which is typical of the true micas of polymorphic modification IM.

Thus, detailed analysis of these samples shows that in this section celadonitization accounts for transformation of nontronite components. This process is accompanied by input and fixation of $\mathrm{K}^{+}$cations within expanding interlayers, liberation of $\mathrm{Fe}^{3+}$ from the tetrahedrons and octahedrons of 2:1 layers, the entrance of $\mathrm{Mg}$ into octahedral positions, and the increase in structural ordering of minerals.

$\mathrm{Fe}^{3+}$ is the main component in the composition of green hydrothermal clays with extremely low amounts of $\mathrm{Al}$ (traces) and rather moderate, permanent amounts of $\mathrm{Mg}$. In relatively pure varieties of hydrothermal clays, the ratio of $\mathrm{Fe} /(\mathrm{Fe}+\mathrm{Mg}+\mathrm{Al}$ ) is 0.8 to 0.9 (see Fig. 1). This sharply differentiates them from clay components of carbonate oozes in the lower part of the section, where the values of $\mathrm{Fe} /(\mathrm{Fe}+\mathrm{Mg}+\mathrm{Al})$ seldom exceed 0.4 . The difference between clay from hydrothermal sediments and clay from carbonate oozes is most distinctly pronounced in comparisons of the $\mathrm{Al} /(\mathrm{Fe}+$ $\mathrm{Mg}+\mathrm{Al}$ ) ratio in the section (see Fig. 1); in hydrothermal sediments, this value rarely exceeds 0.05 , while in carbonate oozes it is, as a rule, about 0.3 to 0.5 . Figure 1 shows these ratios, calculated for typical varieties of montmorillonite, illite, celadonite, glauconite, and nontronite (Weaver and Pollard, 1973; Wise and Eugster, 1964; Kerr, 1950). From these data we may assume that the clay components of carbonate oozes in the lower part of the section are represented by ferruginous montmorillonite-illite. We should also mention that the values of the $\mathrm{K} /(\mathrm{Fe}+\mathrm{Mg}+\mathrm{Al})$ ratio in the section deviate only slightly from 0.1 (see Fig. 1). This is not inconsistent with the conclusions drawn.

\section{Aspects of Geochemistry}

Distinct separation of $\mathrm{Mn}$ and $\mathrm{Fe}$ in the main types of sediments is typical of the hydrothermal deposits we considered. In green clays, which concentrate most of the $\mathrm{Fe}, \mathrm{Mn}$ is practically not accumulated; while the manganese-hydroxide crust-like deposits contain in most 
cases very little $\mathrm{Fe}$ (see Table 2 ). This is clearly seen in the distribution of the $\mathrm{Mn} / \mathrm{Fe}$ ratio over the sequence (Fig. 6). In the lower part of the section, composed of foraminifer-nannofossil sediments, the $\mathrm{Mn} / \mathrm{Fe}$ value substantially exceeds values typical for ocean basalts, carbonates, and clay sediments (Turekian and Wedepohl, 1961). In addition, there is a distinct tendency for the $\mathrm{Mn} / \mathrm{Fe}$ ratio to increase toward the top of the carbonate sedimentary portions. The latter can be interpreted as an indication of a growth in time of relatively low-temperature hydrothermal activity as a result of activation of the fault area. This conclusion is confirmed by a conformable (with $\mathrm{Mn} / \mathrm{Fe}$ ) change in the values of the $\mathrm{Ba}$ / Ti ratio as a typical indicator of hydrothermal activity. It should be mentioned that the $\mathrm{Ba} / \mathrm{Ti}$ ratio both in hydrothermal deposits (particularly in varieties composed of manganese hydroxides; see Sample 509B-1-2, 65-67 $\mathrm{cm}$ ) and in foraminiferal oozes is essentially higher than in basalts, oceanic carbonates, and clay sediments (see Fig. 6) (Turekian and Wedepohl, 1961). The Ba/Sr values according to the experimental data permit us to separate the relatively high-temperature hydrothermal sedi-

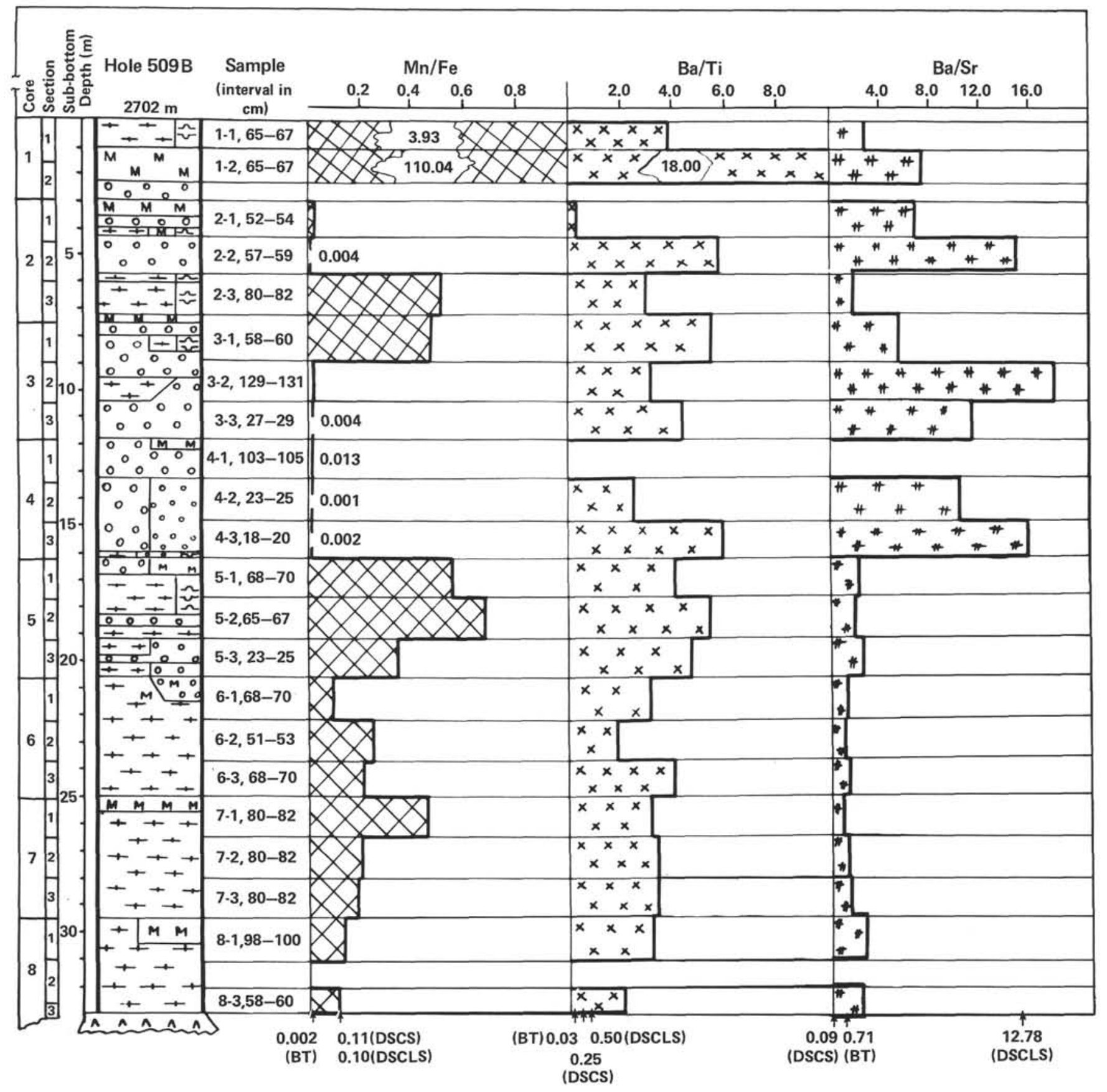

Figure 6. Distribution of $\mathrm{Mn} / \mathrm{Fe}, \mathrm{Ba} / \mathrm{Ti}$, and $\mathrm{Ba} / \mathrm{Sr}$ ratios, Hole $509 \mathrm{~B}$. 
ments, represented by green clays, from the relatively low-temperature varieties composed of manganese hydroxides (Fig. 6). The values of this ratio are particularly distinctly manifested for the hydrothermal sediments as a whole and for foraminiferal oozes (Fig. 6). Nevertheless, the foraminiferal oozes are characterized by the $\mathrm{Ba} / \mathrm{Sr}$ value exceeding this parameter for deep-sea carbonate sediments by 10 - to 20 -fold (Turekian and Wedepohl, 1961).

\section{SITE 507}

Site 507 occupies a small, $1-\times 2-\mathrm{km}$ portion of the region of hydrothermal mounds; we studied all three holes: 507D, 507F, 507H (see Site 507 report).

\section{Hole 507D}

Hole 507D was drilled on a hydrothermal mound; from it was recovered a 26-meter-thick section of green hydrothermal clay, alternating in some intervals with siliceous foraminiferal nannofossil oozes, and a 10-meter-thick unit of foraminiferal nannofossil oozes. A detailed description of the hole is given in the site summary, this volume (Figs. 7, 8; Table 5).

\section{Mineralogy}

In this hole, hydrothermal sediments are predominantly represented by green globular clays. XRD and IR-spectroscopy identified two types of such clays. The first is represented by clays composed of a continuous series of mixed-layer phases with differing content of mica and smectite layers. The diffraction patterns of these clays have weakly expressed diffraction plateau shaped peaks and do not permit us to estimate even approximately the relationship between different layers (Samples 507D-2-1, 30-32; 507D-6-2, 43-45; 507D-7-3, $131-135$; 507D-8-1, 77-79). The second type is represented by a mixed-layer phase, with Fe-mica and Fesmectite in the proportion 70:30 and disordered alternation (Samples 507D-3-1, 80-82; 507D-3-3, 21-23; 507D4-2, 45-47; 507D-5-3, 28-30; Fig. 7). Sample 507D-4-1, 62-64 has a particularly distinct tendency toward segregation of different layers. The distribution of $\mathrm{Fe} /(\mathrm{Fe}$ $+\mathrm{Mg}+\mathrm{Al}$ ) in the sequence shows that in the lower part of the hydrothermal sediment unit (i.e., Sample 507D$6-2,43-45 \mathrm{~cm}$ and below), green clays of the first type predominate, the value of this ratio does not exceed 0.80 ; while for the mixed-layer phases with relatively segregated celadonite and nontronite layers, this parameter exceeds 0.85 and reaches 0.90 (Table 5). On the basis of microscopic study of these sediments it can be concluded that the decrease in ferrugineity of green clays derives from their contamination by residual products after dissolution of siliceous-carbonate oozes by hydrothermal solutions. Thus, the tendency toward increasing celadonitization with depth, detected during the study of Hole 509B, is also true for this hole, except for the lower green clays, which were contaminated by residual products of dissolution.

As in the case of Hole 509B (Fig. 1), the clay material of the foraminiferal nannofossil oozes shows a rela- tively higher concentration of $\mathrm{Al}$ as compared to the green hydrothermal clays.

\section{Aspects of Geochemistry}

The distribution patterns of $\mathrm{Mn} / \mathrm{Fe}, \mathrm{Ba} / \mathrm{Ti}$, and $\mathrm{Ba} /$ $\mathrm{Sr}$ ratios established for Hole 509B sediments (Fig. 6) are also true as a whole for this section (Fig. 8). Deviations may result from the contaminating and diluting effects of the products of dissolution of siliceous-carbonate sediments during their interaction with hydrothermal solutions.

\section{Hole 507F}

Hole $507 \mathrm{~F}$ was drilled $50 \mathrm{~km}$ WNW along the strike of a hydrothermal mound-like ridge from Hole 507D (Table 6). The hole was drilled on the flank of a mound. The upper, 15-meter-thick, siliceous foraminiferal nannofossil sediments contain a 2-meter-thick unit of green hydrothermal clays and are underlain by foraminiferalnannofossil ooze (see site summary).

\section{Mineralogy}

XRD indicates that the green hydrothermal clays are composed of different types of mixed-layered, highly ferruginous phases of mica-smectite. One type is composed of pockets $\left(W_{m}: W_{s}=0.8: 0.2\right.$ and $\left.0.2: 0.8\right)$ which alternate completely at random (Sample 507F-2-2, 80$82 \mathrm{~cm}$ ). They have an admixture of feldspars and quartz (Fig. 9). As in the case of Hole 509B, the clay components of hydrothermal and siliceous-carbonate pelagic sediments sharply differ in $\mathrm{Fe}$ and $\mathrm{Al}$ concentrations. These differences are reflected in the distribution of $\mathrm{Fe} /$ $(\mathrm{Fe}+\mathrm{Mg}+\mathrm{Al})$ and $\mathrm{Al} /(\mathrm{Fe}+\mathrm{Mg}+\mathrm{Al})$ ratios (see Fig. 9). These data show that the clay matter of siliceous-carbonate sediments is composed of a weakly ferruginized montmorillonite-illite-i.e. components that are essentially different from the hydrothermal clays.

\section{Aspects of Geochemistry}

The main distribution tendencies of $\mathrm{Mn} / \mathrm{Fe}, \mathrm{Ba} / \mathrm{Ti}$, and $\mathrm{Ba} / \mathrm{Sr}$ ratios which were established for Hole 509B (Fig. 6) are also true for Hole 507F (Fig. 10). However, comparison of the data reveal relatively smaller values for these ratios, which may be a consequence of the somewhat weakened effect of hydrothermal emissions on sedimentation. The position of the hole on the flank of a hydrothermal mound and the relatively small proportion of hydrothermal sediments $(2 \mathrm{~m})$ in the total section of deposits $(29 \mathrm{~m})$ is not inconsistent with this interpretation.

\section{Hole 507H}

Hole $507 \mathrm{H}$ was drilled 200 meters to the south of Hole 507D in an area remote from the hydrothermal mounds; from it was recovered a 32-meter-thick unit of pelagic sediments (including, downward from the top oozes, 4-meter-thick weakly siliceous varieties, and 14 to 15-meter-thick foraminiferal nannofossil sediments in the lower part of the sequence) without any notable traces of green hydrothermal clays (see site summary and Table 7). 


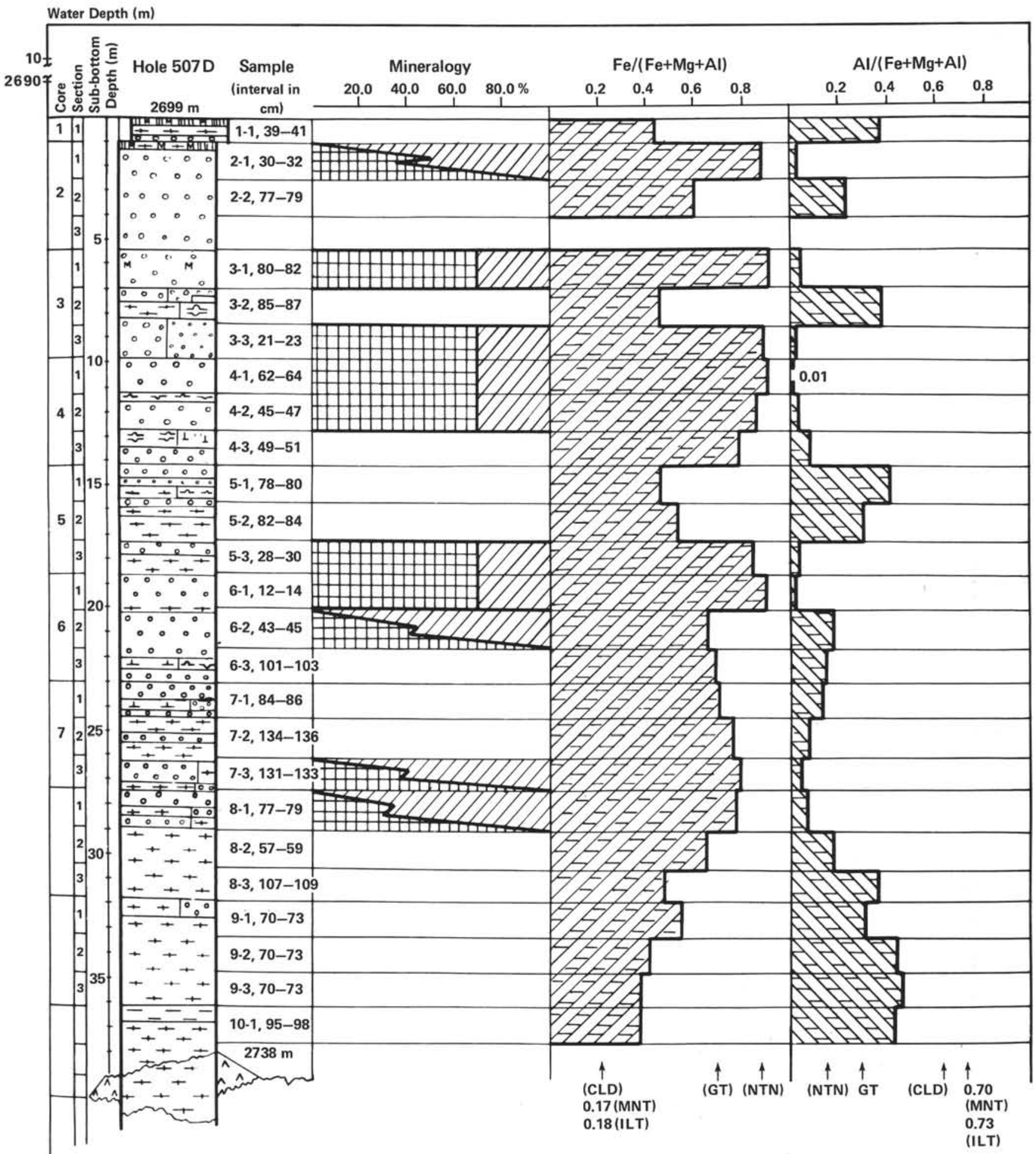

Figure 7. Distribution of mineral components and the ratios of $\mathrm{Fe} /(\mathrm{Fe}+\mathrm{Mg}+\mathrm{Al})$ and $\mathrm{Al} /(\mathrm{Fe}+\mathrm{Mg}+\mathrm{Al}), \mathrm{Hole} 507 \mathrm{D}$.

\section{Aspects of Mineralogy and Geochemistry}

The mineral composition of pelagic sediments from Hole $507 \mathrm{H}$ is close to that described for Hole 509B (Fig. 6). Distribution of $\mathrm{Fe} /(\mathrm{Fe}+\mathrm{Mg}+\mathrm{Al})$ and $\mathrm{Al} /(\mathrm{Fe}+\mathrm{Mg}$ $+\mathrm{Al}$ ) ratios in Hole $507 \mathrm{H}$ is relatively homogeneous and indicates that clay components are represented by weakly ferruginous montmorillonite-illite. Any perceptible traces of hydrothermal clays with typical, extremely low amounts of $\mathrm{Al} / \mathrm{Al}(\mathrm{Fe}+\mathrm{Mg}+\mathrm{Al})<0.1$ were not established in this section. The $\mathrm{Mn} / \mathrm{Fe}, \mathrm{Ba} / \mathrm{Sr}$, and particularly the $\mathrm{Ba} / \mathrm{Ti}$ ratios slightly exceed the values for deep-sea carbonate sediments. This indicates the effect of hydrothermal emissions on siliceous-carbonate sedi- 


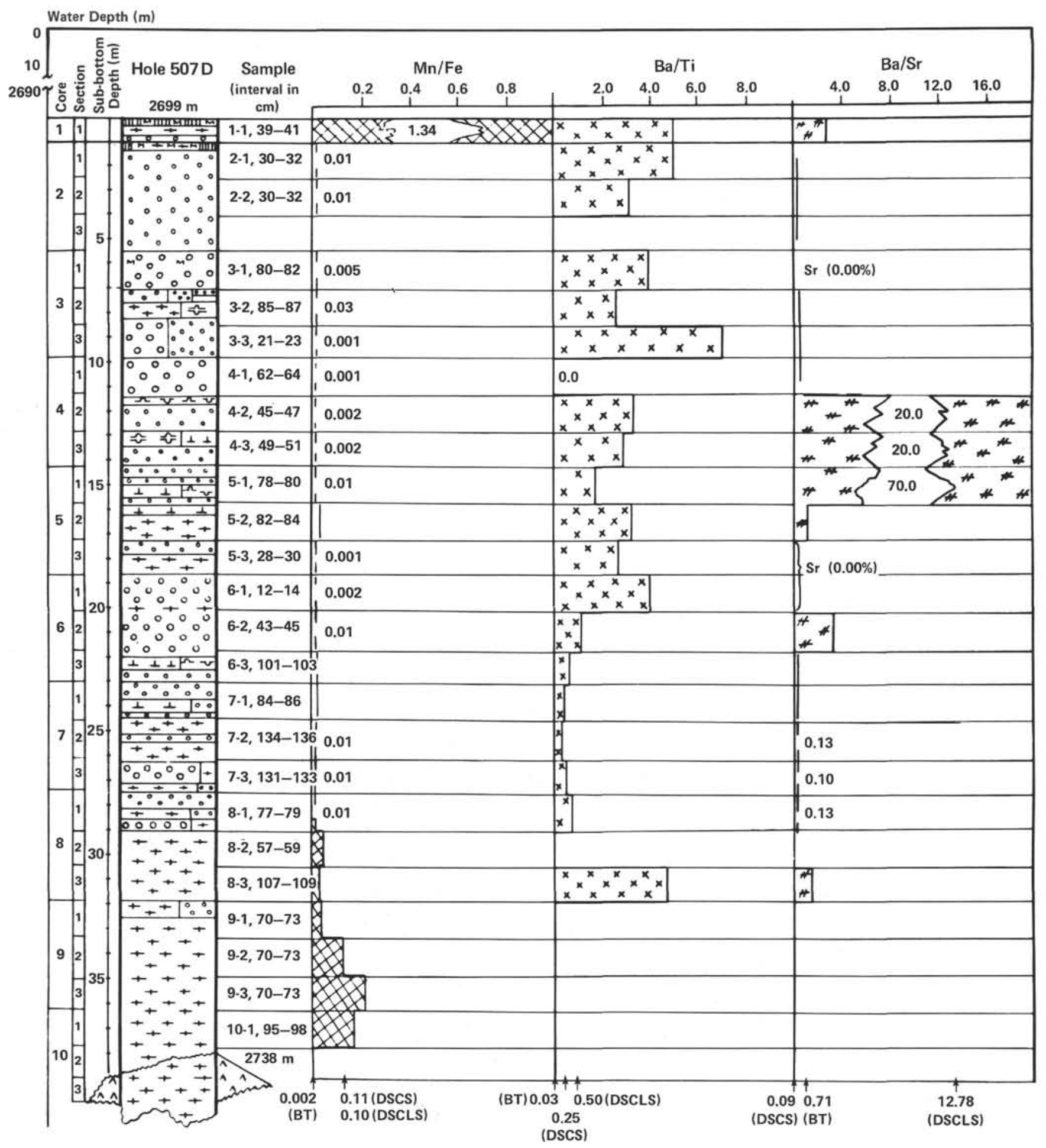

Figure 8. Distribution of ratios: $\mathrm{Mn} / \mathrm{Fe}, \mathrm{Ba} / \mathrm{Ti}, \mathrm{Ba} / \mathrm{Sr}$, Hole 507D.

ments in this area. However, compared to those holes drilled on top of hydrothermal mounds and correspondingly less removed from basement faults, the effect of hydrothermal emissions on sedimentation in these sections manifests itself relatively weakly (Fig. 6).

\section{SITE 506}

Site 506 is a relatively limited area $(1 \times 2 \mathrm{~km})$ of rather large hydrothermal mounds and ridges (15-20 m high) with high heat flow and considerable hydrothermal activity (see Site 506 report).

\section{Hole 506}

Hole 506 was drilled on the top of a hydrothermal mound. The composition of the sediments recovered is described in the site summary, this volume. It should be emphasized that the true stratigraphic sequence begins at the top of Core 2 (Fig. 11; Table 8). The thickness of 
HYDROTHERMAL DEPOSITS

Table 5. Chemical composition of upper Cenozoic sediments, Hole 507D.

\begin{tabular}{|c|c|c|c|c|c|c|c|c|c|c|c|c|c|}
\hline No. & $\begin{array}{c}\text { Sample } \\
\text { (interval in } \mathrm{cm} \text { ) }\end{array}$ & $\mathrm{SiO}_{2}$ & $\mathrm{TiO}_{2}$ & $\mathrm{Al}_{2} \mathrm{O}_{3}$ & $\mathrm{Fe}_{2} \mathrm{O}_{3}$ & $\mathrm{MnO}$ & $\begin{array}{l}\mathrm{MgO} \\
\mathrm{vt} . \% \text {; ai }\end{array}$ & $\begin{array}{c}\mathrm{CaO} \\
\text {-dried) }\end{array}$ & $\mathrm{P}_{2} \mathrm{O}_{5}$ & $\mathrm{Na}_{2} \mathrm{O}$ & $\mathrm{K}_{2} \mathrm{O}$ & $\mathrm{BaO}$ & $\mathrm{SrO}$ \\
\hline 1 & $1-1,39-41$ & 16.44 & 0.11 & 3.60 & 3.27 & 3.95 & 1.61 & 28.92 & 0.14 & 4.44 & 0.51 & 0.39 & 0.15 \\
\hline 2 & $2-1,30-32$ & 44.45 & 0.05 & 1.37 & 27.96 & 0.24 & 3.18 & 0.00 & 0.08 & 3.38 & 1.26 & 0.168 & 0.00 \\
\hline 3 & $2-2,77-79$ & 39.62 & 0.24 & 5.51 & 11.22 & 0.11 & 3.48 & 2.40 & 0.13 & 9.24 & 1.42 & 0.498 & 0.00 \\
\hline 4 & $3-1,80-82$ & 45.83 & 0.06 & 1.68 & 26.42 & 0.11 & 3.42 & 0.00 & 0.07 & 4.33 & 1.98 & 0.175 & 0.00 \\
\hline 5 & $3-2,85-87$ & 44.27 & 0.35 & 8.54 & 7.91 & 0.18 & 3.32 & 2.57 & 0.12 & 8.54 & 1.57 & 0.607 & 0.00 \\
\hline 6 & $3-3,21-23$ & 47.65 & 0.02 & 0.88 & 28.67 & 0.03 & 3.24 & 0.00 & 0.05 & 2.89 & 1.98 & 0.082 & 0.00 \\
\hline 7 & $4-1,62-64$ & 48.94 & 0.004 & 0.38 & 29.36 & 0.02 & 3.37 & 0.00 & 0.02 & 2.25 & 2.86 & 0.000 & 0.00 \\
\hline 8 & $4-2,45-47$ & 48.37 & 0.05 & 1.40 & 27.05 & 0.04 & 3.73 & 0.00 & 0.06 & 3.43 & 2.00 & 0.107 & 0.006 \\
\hline 9 & $4-3,49-51$ & 44.94 & 0.11 & 3.01 & 22.58 & 0.05 & 4.28 & 0.00 & 0.06 & 5.67 & 2.37 & 0.223 & 0.008 \\
\hline 10 & $5-1,78-80$ & 52.46 & 0.29 & 9.81 & 8.47 & 0.08 & 2.75 & 0.40 & 0.09 & 7.02 & 2.92 & 0.309 & 0.005 \\
\hline 11 & $5-2,82-84$ & 12.55 & 0.11 & 2.99 & 3.90 & 0.22 & 1.45 & 36.68 & 0.10 & 3.07 & 0.53 & 0.213 & 0.204 \\
\hline 12 & $5-3,28-30$ & 47.89 & 0.05 & 1.30 & 27.71 & 0.03 & 4.57 & 0.00 & & 3.56 & 2.74 & 0.085 & 0.00 \\
\hline 13 & $6-1,12-14$ & 47.22 & 0.02 & 0.76 & 29.30 & 0.05 & 3.25 & 0.90 & 0.05 & 2.84 & 2.28 & 0.043 & 0.00 \\
\hline 14 & $6-2,43-45$ & 34.75 & 0.20 & 4.87 & 13.90 & 0.11 & 4.02 & 10.14 & 0.10 & 6.94 & 1.78 & 0.148 & 0.05 \\
\hline 15 & $6-3,101-103$ & 16.07 & 0.08 & 2.23 & 7.69 & 0.22 & 2.07 & 33.49 & 0.04 & 3.29 & 0.64 & 0.032 & 0.199 \\
\hline 16 & $7-1,84-86$ & 19.82 & 0.08 & 2.39 & 9.12 & 0.23 & 2.45 & 30.31 & 0.07 & 3.13 & 1.25 & 0.019 & 0.141 \\
\hline 17 & $7-2,134-136$ & 29.52 & 0.05 & 2.13 & 15.40 & 0.14 & 3.53 & 21.55 & 0.06 & 2.93 & 1.60 & 0.012 & 0.097 \\
\hline 18 & $7-3,131-133$ & 26.22 & 0.03 & 1.11 & 14.59 & 0.17 & 3.40 & 24.02 & 0.04 & 3.08 & 1.31 & 0.012 & 0.124 \\
\hline 19 & $8-1,77-79$ & 24.13 & 0.06 & 1.63 & 13.10 & 0.17 & 2.96 & 25.52 & 0.04 & 3.21 & 1.41 & 0.021 & 0.183 \\
\hline 20 & $8-2,57-59$ & 8.56 & 0.04 & 1.50 & 4.16 & 0.34 & 1.23 & 45.69 & 0.04 & 2.05 & 0.48 & & 0.177 \\
\hline 21 & $8-3,107-109$ & 11.50 & 0.11 & 3.26 & 3.28 & 0.18 & 1.31 & 37.86 & 0.05 & 2.72 & 0.50 & 0.315 & 0.230 \\
\hline 22 & $9-1,70-73$ & 10.13 & 0.08 & 2.54 & 3.38 & 0.20 & 1.02 & 43.25 & 0.04 & 2.27 & 0.48 & & 0.184 \\
\hline 23 & $9-2,70-73$ & 6.45 & 0.06 & 2.18 & 1.54 & 0.20 & 0.63 & 47.31 & 0.01 & 2.00 & 0.31 & & 0.199 \\
\hline 24 & $9-3,70-73$ & 7.51 & 0.07 & 2.31 & 1.42 & 0.29 & 0.77 & 46.54 & 0.03 & 2.14 & 0.34 & & 0.214 \\
\hline 25 & $10-1,95-98$ & 8.95 & 0.12 & 2.73 & 1.81 & 0.28 & 1.15 & 44.77 & 0.01 & 2.40 & 0.37 & & 0.140 \\
\hline
\end{tabular}

Table 6. Chemical composition of upper Cenozoic sediments, Hole 507F.

\begin{tabular}{|c|c|c|c|c|c|c|c|c|c|c|c|c|c|}
\hline No. & $\begin{array}{c}\text { Sample } \\
\text { (interval in } \mathrm{cm} \text { ) }\end{array}$ & $\mathrm{SiO}_{2}$ & $\mathrm{TiO}_{2}$ & $\mathrm{Al}_{2} \mathrm{O}_{3}$ & $\mathrm{Fe}_{2} \mathrm{O}_{3}$ & $\mathrm{MnO}$ & $\begin{array}{l}\mathrm{MgO} \\
. \% \text {; a }\end{array}$ & $\begin{array}{l}\mathrm{CaO} \\
\text {-dried) }\end{array}$ & $\mathrm{P}_{2} \mathrm{O}_{5}$ & $\mathrm{Na}_{2} \mathrm{O}$ & $\mathrm{K}_{2} \mathrm{O}$ & $\mathrm{BaO}$ & $\mathrm{SrO}$ \\
\hline 1 & $1-1,80-82$ & 11.46 & 0.06 & 1.90 & 1.01 & 0.40 & 0.78 & 42.93 & 0.03 & 2.72 & 0.33 & & 0.120 \\
\hline 2 & $2-2,80-82$ & 47.28 & 0.03 & 1.06 & 28.08 & 0.03 & 3.42 & 0.00 & 0.03 & 2.76 & 1.59 & 0.067 & 0.000 \\
\hline 3 & $2-3,53-55$ & 44.29 & 0.22 & 5.49 & 18.68 & 0.07 & 3.67 & 0.00 & 0.09 & 6.35 & 1.33 & 0.510 & 0.027 \\
\hline 4 & $2-3,118-120$ & 41.73 & 0.29 & 6.96 & 13.13 & 0.10 & 4.07 & 0.220 & 0.11 & 8.90 & 1.72 & 0.536 & 0.02 \\
\hline 5 & $3-1,68-70$ & 20.70 & 0.13 & 3.64 & 4.21 & 0.39 & 1.72 & 32.86 & 0.09 & 4.05 & 0.63 & 0.370 & 0.162 \\
\hline 6 & $3-3,68-70$ & 15.98 & 0.11 & 3.11 & 3.73 & 0.29 & 1.22 & 37.82 & 0.08 & 3.50 & 0.54 & 0.304 & 0.171 \\
\hline 7 & $4-3,71-73$ & 9.86 & 0.08 & 2.57 & 1.81 & 0.24 & 1.03 & 44.30 & 0.03 & 2.66 & 0.32 & 0.182 & 0.211 \\
\hline 8 & $5-2,75-77$ & 9.00 & 0.07 & 2.47 & 2.32 & 0.20 & 0.74 & 45.31 & 0.05 & 2.37 & 0.39 & 0.243 & 0.192 \\
\hline 9 & $6-2,75-77$ & 9.58 & 0.09 & 2.92 & 2.02 & 0.21 & 0.77 & 45.15 & 0.05 & 2.33 & 0.42 & 0.236 & 0.183 \\
\hline 10 & $7-1,70-72$ & 8.05 & 0.08 & 2.62 & 1.58 & 0.21 & 0.69 & 46.01 & 0.05 & 2.28 & 0.31 & 0.201 & 0.169 \\
\hline 11 & $7-2,70-72$ & 12.46 & 0.13 & 3.71 & 1.98 & 0.18 & 1.14 & 42.70 & 0.04 & 2.49 & 0.42 & 0.326 & 0.132 \\
\hline 12 & $7-3,70-72$ & 17.13 & 0.43 & 4.68 & 4.31 & 0.30 & 2.22 & 39.16 & 0.13 & 1.99 & 0.32 & 0.155 & 0.088 \\
\hline 13 & $8-1,70-72$ & 12.53 & 0.13 & 2.47 & 24.79 & 0.47 & 1.51 & 28.13 & 0.09 & 2.09 & 0.47 & & 0.095 \\
\hline 14 & $9-1,20-22$ & 9.02 & 0.09 & 2.45 & 2.51 & 0.55 & 1.37 & 43.29 & 0.04 & 1.90 & 0.19 & & 0.134 \\
\hline
\end{tabular}

the hydrothermal clay unit is 9.5 meters; it is underlain by a 10-meter-thick unit of foraminiferal-nannofossil ooze.

\section{Mineralogy}

X-ray diffraction indicates that the green hydrothermal clays are represented by mixed-layer, disordered phases of Fe-mica (celadonite) and Fe-smectite (nontronite) in the relative proportion of 80:20 (Samples $506-3-2,136-138 \mathrm{~cm} ; 506-3-3,38-40 \mathrm{~cm} ; 506-4-2,110$ $112 \mathrm{~cm}$ ) (Drits and Sakharov, 1976). The samples contain very small amounts of biomorphic calcite and have a peculiarly high $\mathrm{Fe}$ content $[\mathrm{Fe} /(\mathrm{Fe}+\mathrm{Mg}+\mathrm{Al})>0.75]$ and rather low concentrations of $\mathrm{Al}[\mathrm{Al} /(\mathrm{Fe}+\mathrm{Mg}+\mathrm{Al})$ $<0.10$ ] (Fig. 11). Compared to this group of relatively homogeneous samples, the underlying green clay (Sample 506-4-3, 100-102) is represented by a continuous sequence of mixed-layer phases with varying composition and extremely indefinitely established relationships between the mica and smectite layers. The clays contain notable amounts of phillipsite and quartz. This sample has a relatively higher concentration of $\mathrm{Al} /(\mathrm{Fe}+\mathrm{Mg}$ $+\mathrm{Al})>0.15$. The chemical and mineral composition of this variety of green clay suggests that it is substantially enriched in residual products from the dissolution of pelagic siliceous-carbonate oozes.

\section{Aspects of Geochemistry}

Distribution features of $\mathrm{Mn}, \mathrm{Fe}, \mathrm{Ba}$, and $\mathrm{Sr}$ in the section of hydrothermal and pelagic sediments described earlier are observed also in Hole 506 (Table 8); namely, the green hydrothermal clays are impoverished in manganese $(\mathrm{Mn} / \mathrm{Fe}<0.05)$, but show relatively high values of $\mathrm{Ba} / \mathrm{Ti}$ and $\mathrm{Ba} / \mathrm{Sr}$.

\section{Hole 506C}

Hole $506 \mathrm{C}$ was drilled on a hydrothermal mound (Table 9). The lithology of the hole is described in the site summary, this volume. The sedimentary section is rather unevenly characterized by the samples. Total thickness of green hydrothermal clays is about 9 meters.

\section{Mineralogy}

X-ray diffraction and IR-spectroscopy indicate that the upper unit of green hydrothermal clays comprises ferruginous, disordered, mixed-layer phases of mica (cel- 


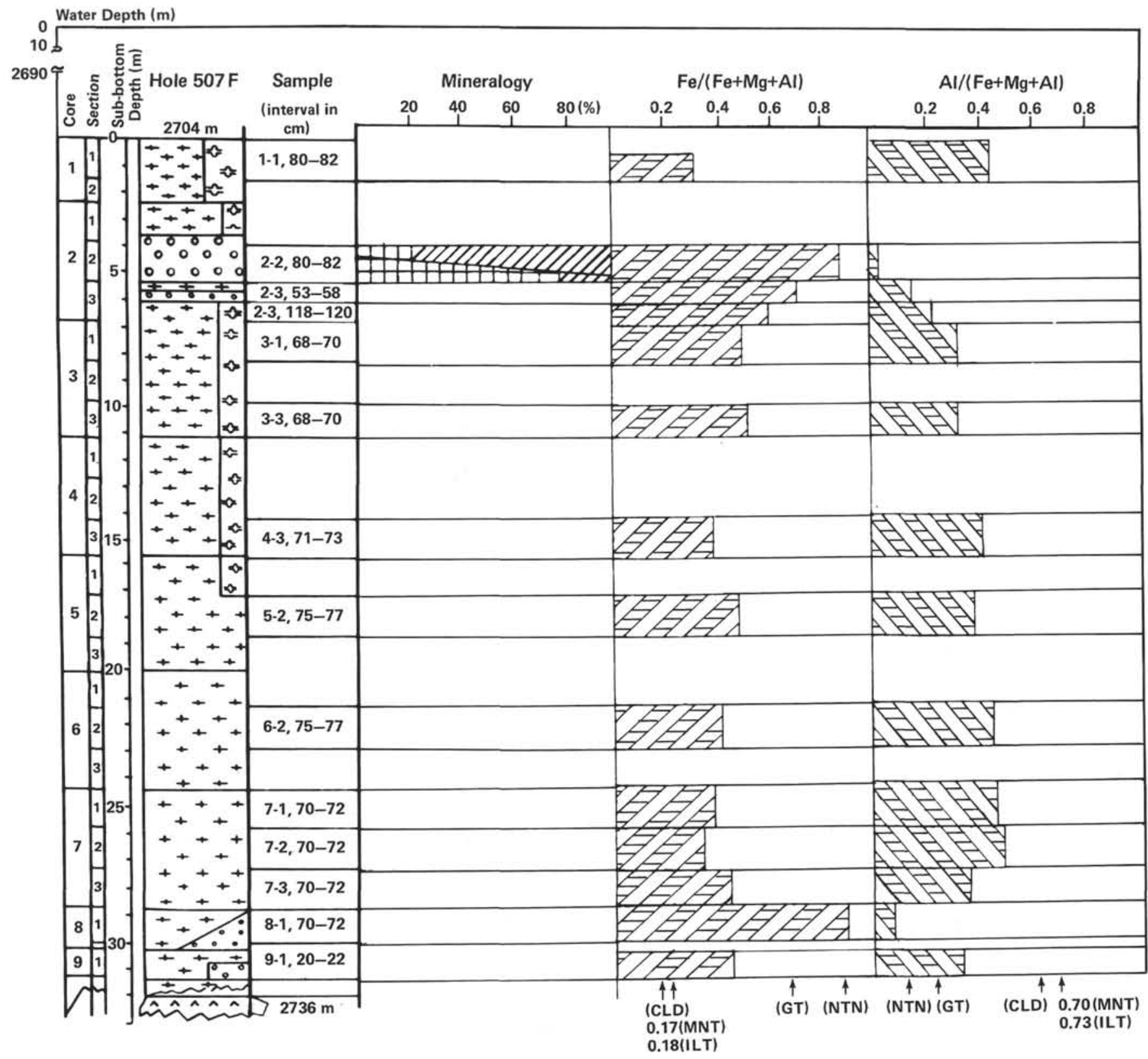

Figure 9. Distribution of mineral components and the ratios of $\mathrm{Fe} /(\mathrm{Fe}+\mathrm{Mg}+\mathrm{Al})$ and $\mathrm{Al} /(\mathrm{Fe}+\mathrm{Mg}+\mathrm{Al}), \mathrm{Hole} 507 \mathrm{~F}$.

adonite) and smectite (nontronite) in the proportion 60 : 40 (Sample 506C-4-1, 105-107 cm). The lower unit (Sample $506 \mathrm{C}-8-1,81-83 \mathrm{~cm}$ ) comprises similar clays, with the proportion of celadonite to nontronite layers approximately $70: 30$.

As in the holes considered previously, the green clays show high concentrations of Fe (Table 9) and extremely low amounts of $\mathrm{Al}[\mathrm{Al} /(\mathrm{Fe}+\mathrm{Mg}+\mathrm{Al})<0.05]$. In clay components of foraminiferal-nannofossil oozes, this ratio usually exceeds 0.3 . This permits us to classify clay components of these sediments as weakly ferruginous montmorillonite-illite.

\section{Aspects of Geochemistry}

The trends for $\mathrm{Mn}, \mathrm{Fe}, \mathrm{Ba}, \mathrm{Sr}$, and other components observed in Hole 509B hold true for these sediments.
The green hydrothermal clays are extremely impoverished in $\mathrm{Mn}$; high $\mathrm{Ba} / \mathrm{Ti}$ and $\mathrm{Ba} / \mathrm{Sr}$ values, observed not only in hydrothermal sediments but also in carbonate pelagic oozes, are evidence of a considerable influence of hydrothermal emissions on sedimentation.

\section{DISCUSSION}

Data from XRD, IR-spectroscopy, electron diffractometry, and chemical analysis (Tables 2, 5-9, Figs. 2-5) reveal that the hydrothermal green clays comprise disordered, mixed-layer phases of Fe-mica (celadonite) and Fe-smectite (nontronite). A number of sections show a tendency for celadonitization to increase with depth: the number of celadonite layers reaches $80 \%$. Celadonitization is as a rule accompanied by an increase in structural ordering. Electron diffractometry shows that the pa- 


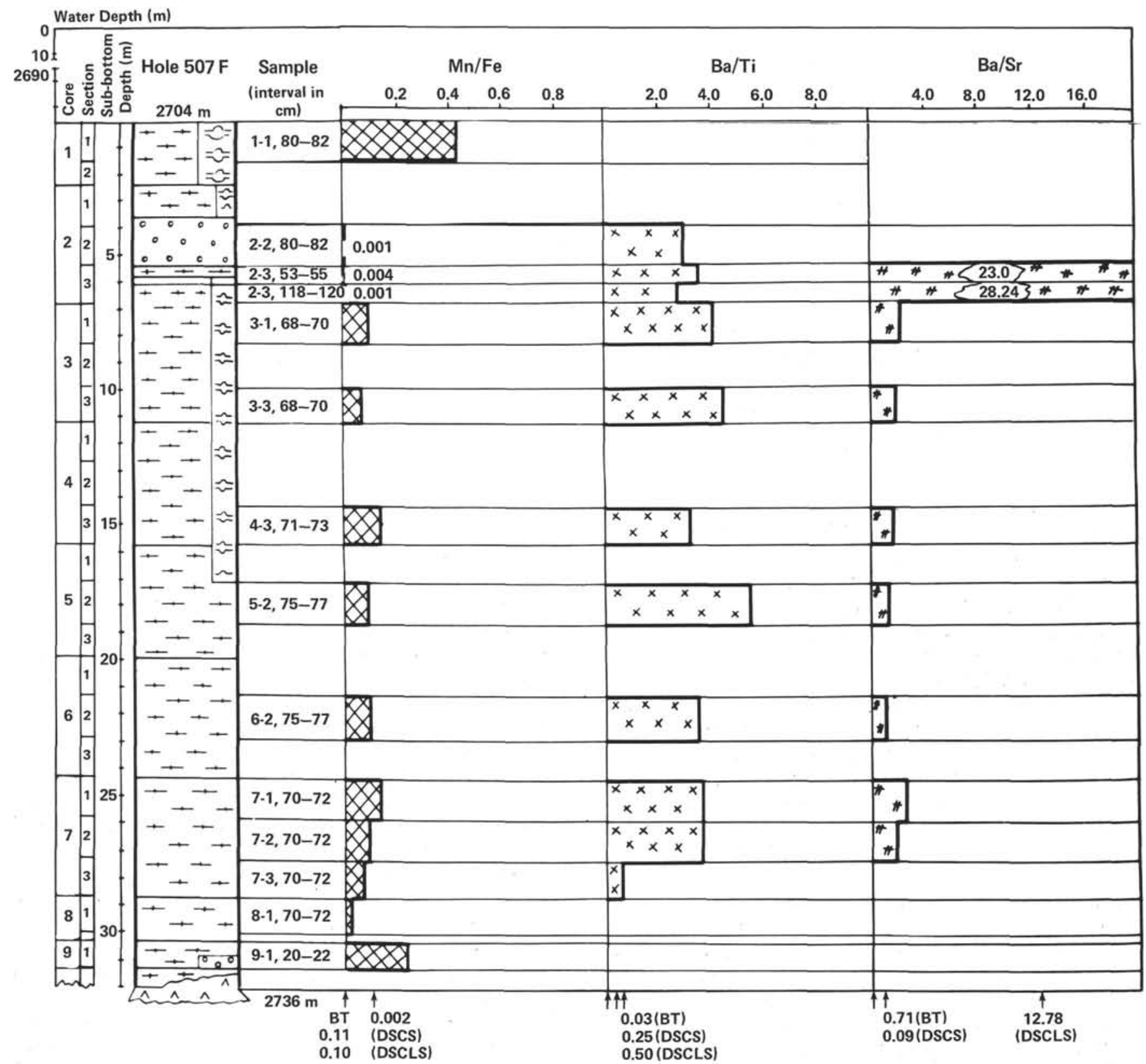

Figure 10. Distribution of $\mathrm{Mn} / \mathrm{Fe}, \mathrm{Ba} / \mathrm{Ti}$, and $\mathrm{Ba} / \mathrm{Sr}$ ratios, Hole $507 \mathrm{~F}$.

rameters of unit cells and the degrees of three-dimensional ordering are close to the $\mathrm{Fe}$-micas of polymorphic modification IM (see Table 3, Fig. 5). The most typical varieties of green clays comprise essentially ferruginous compounds with traces or rather insignificant concentrations of $\mathrm{Al}_{2} \mathrm{O}_{3}$ (see Table 2, 5-9) and relatively constant and moderate contents of $\mathrm{Mg}$. These features are reflected in the fact that the $\mathrm{Al} /(\mathrm{Fe}+\mathrm{Mg}+\mathrm{Al})$ ratio usually does not exceed 0.001 to 0.01 , while for the clay components of siliceous foraminiferal-nannofossil oozes this ratio is distinctly higher than 0.3 to 0.5 (see Figs. 1, $8,9,11)$. Correspondingly, for pure varieties of hydrothermal clays, the $\mathrm{Fe} /(\mathrm{Fe}+\mathrm{Mg}+\mathrm{Al})$ ratio does not drop below 0.8 to 0.9 . It should be emphasized that the tendency of celadonitization to increase with depth is most typical of relatively pure, highly ferruginous varieties, uncontaminated with the products resulting from dissolution of siliceous-carbonate, weakly clayey pelagic sediments. It is noted that the contaminated types of green clays are composed of extremely disordered mixedlayer phases of celadonite-smectite; their $\mathrm{Fe} /(\mathrm{Fe}+\mathrm{Mg}$ $+\mathrm{Al}$ ) ratios are peculiarly low, not exceeding 0.5 to 0.7 . Such clays contain an admixture of feldspar, quartz, and zeolite (mainly phillipsite). The established parameters of green hydrothermal clays are in good agreement with structural features observed by optical as well as scanning and transmission electron microscopes. Where there are a substantial number of nontronite layers, the varieties have a distinctly expressed globular texture (see Plates 4,5 ). Those varieties where the content of cela- 
Table 7. Chemical composition of upper Cenozoic sediments, Hole 507H.

\begin{tabular}{|c|c|c|c|c|c|c|c|c|c|c|c|c|c|}
\hline No. & $\begin{array}{c}\text { Sample } \\
\text { (interval in } \mathrm{cm} \text { ) }\end{array}$ & $\mathrm{SiO}_{2}$ & $\mathrm{TiO}_{2}$ & $\mathrm{Al}_{2} \mathrm{O}_{3}$ & $\mathrm{Fe}_{2} \mathrm{O}_{3}$ & $\mathrm{MnO}$ & $\begin{array}{l}\mathrm{MgO} \\
\text { t. } \% \text {; ai }\end{array}$ & $\begin{array}{c}\mathrm{CaO} \\
\text {-dried) }\end{array}$ & $\mathrm{P}_{2} \mathrm{O}_{5}$ & $\mathrm{Na}_{2} \mathrm{O}$ & $\mathrm{K}_{2} \mathrm{O}$ & $\mathrm{BaO}$ & $\mathrm{SrO}$ \\
\hline 1 & $1-1,79-81$ & 19.82 & 0.11 & 2.94 & 1.94 & 0.24 & 1.14 & 32.38 & 0.08 & 3.37 & 0.42 & 0.192 & 0.108 \\
\hline 2 & $1-2,79-81$ & 21.50 & 0.10 & 2.75 & 1.49 & 0.25 & 1.20 & 33.90 & 0.08 & 3.31 & 0.39 & 0.251 & 0.244 \\
\hline 3 & $2-1,79-81$ & 25.97 & 0.12 & 3.36 & 1.85 & 0.24 & 1.48 & 30.11 & 0.06 & 3.98 & 0.49 & 0.267 & 0.223 \\
\hline 4 & $2-2,79-81$ & 23.31 & 0.17 & 4.34 & 2.40 & 0.32 & 1.44 & 33.65 & 0.10 & 3.16 & 0.59 & 0.376 & 0.383 \\
\hline 5 & $2-3,79-81$ & 19.42 & 0.13 & 3.88 & 2.01 & 0.19 & 1.13 & 35.16 & 0.06 & 2.60 & 0.53 & 0.284 & 0.283 \\
\hline 6 & $3-1,48-50$ & 23.14 & 0.13 & 3.69 & 2.07 & 0.23 & 1.37 & 31.65 & 0.05 & 3.54 & 0.58 & 0.303 & 0.227 \\
\hline 7 & $3-2,48-50$ & 27.82 & 0.18 & 4.95 & 2.65 & 0.28 & 1.72 & 33.31 & 0.11 & 3.81 & 0.70 & 0.395 & 0.289 \\
\hline 8 & $4-1,60-62$ & 16.33 & 0.10 & 3.09 & 2.13 & 0.21 & 0.94 & 38.4 & 0.03 & 2.94 & 0.36 & & 0.084 \\
\hline 9 & $4-3,60-62$ & 13.78 & 0.07 & 2.41 & 3.08 & 0.20 & 1.04 & 39.79 & 0.05 & 3.11 & 0.41 & & 0.095 \\
\hline 10 & $5-1,110-112$ & 12.40 & 0.12 & 3.14 & 2.11 & 0.17 & 1.14 & 42.93 & 0.03 & 2.58 & 0.41 & 0.191 & 0.130 \\
\hline 11 & $5-2,110-112$ & 13.57 & 0.09 & 3.13 & 1.51 & 0.20 & 1.08 & 41.78 & 0.06 & 2.47 & 0.55 & 0.255 & 0.125 \\
\hline 12 & $5-3,110-112$ & 9.51 & 0.09 & 2.45 & 1.31 & 0.17 & 1.09 & 45.83 & 0.03 & 2.14 & 0.32 & 0.178 & 0.127 \\
\hline 13 & $6-1,79-81$ & 7.55 & 0.07 & 2.28 & 1.20 & 0.17 & 0.90 & 46.99 & 0.03 & 1.90 & 0.29 & 0.141 & 0.143 \\
\hline 14 & $6-2,79-81$ & 9.12 & 0.09 & 2.71 & 1.63 & 0.17 & 0.95 & 45.02 & 0.02 & 2.13 & 0.33 & 0.210 & 0.130 \\
\hline 15 & $6-3,79-81$ & 11.67 & 0.12 & 3.27 & 2.16 & 0.16 & 1.27 & 42.88 & 0.07 & 2.49 & 0.42 & 0.259 & 0.126 \\
\hline 16 & $7-1,79-81$ & 8.95 & 0.08 & 2.55 & 1.25 & 0.17 & 1.20 & 45.87 & 0.001 & 2.14 & 0.31 & 0.104 & 0.124 \\
\hline 17 & $7-2,79-81$ & 15.85 & 0.14 & 4.08 & 2.74 & 0.18 & 1.51 & 39.14 & 0.11 & 2.73 & 0.62 & 0.355 & 0.122 \\
\hline 18 & $7-3,79-81$ & 12.49 & 0.15 & 3.55 & 2.47 & 0.17 & 1.52 & 42.68 & 0.04 & 2.58 & 0.45 & 0.330 & 0.113 \\
\hline 19 & $8-1,80-82$ & 8.73 & 0.10 & 2.71 & 1.47 & 0.19 & 1.01 & 44.23 & 0.04 & 2.53 & 0.45 & 0.190 & 0.117 \\
\hline 20 & $8-2,60-62$ & 8.72 & 0.09 & 2.61 & 1.68 & 0.38 & 1.10 & 45.01 & 0.04 & 1.9 & 0.32 & 0.137 & 0.142 \\
\hline
\end{tabular}

donite layers in mixed-layer phase makes up $80 \%$ indicate a distinct development of fibrous and flaky crystallites of Fe-mica (see Plate 6).

Manganese-hydroxide crusts are composed of todorokite (buserite) (Frenzel, 1980; Giovanoli, 1980) with a pronounced globular texture and distinct crystallization (see Fig. 4, Plates 1-3).

Clear separation of $\mathrm{Mn}$ and $\mathrm{Fe}$ is a rather important geochemical feature of the hydrothermal accumulations being considered. Green clays, composed essentially of ferruginous compounds, contain extremely small trace amounts of manganese. The $\mathrm{Fe}$ content in the crusts of manganese hydroxides rarely exceeds $1 \%$. This peculiarity finds its reflection in the distribution of the $\mathrm{Mn} / \mathrm{Fe}$ ratio in the hole sections (see Figs. 6, 8, 10).

The $\mathrm{Ba} / \mathrm{Ti}$ and $\mathrm{Ba} / \mathrm{Sr}$ ratios (see Figs. $6,8,10$ ) also indicate hydrothermal accumulations. It should be emphasized that high $\mathrm{Ba} / \mathrm{Sr}$ ratios are characteristic of rather pure, highly ferruginous varieties of green clays deposited from relatively high-temperature solutions.

The work of a number of researchers (Bishoff, 1969; Bishoff and Dickson, 1975; Mottl and Holland, 1978; Mottl et al., 1979; Seyfried and Bishoff, 1977; Seyfried and Mottl, 1977; Varentsov, 1971; Varentsov and Stepanets, 1970) suggests that the observed facts are not inconsistent with the concepts of Hekinian et al. (1980) and Dymond et al. (1980). It should be noted that deposition of the sediments composing the hydrothermal mounds took place from the moderately heated (200$400^{\circ} \mathrm{C}$ ), transformed solutions of seawater, which extracted $\mathrm{SiO}_{2}, \mathrm{Fe}, \mathrm{Mn}$, and other heavy metals from the solid basalts of the basement. The presence of hydrothermal solutions near or slightly below the surface of pelagic sediments occurred in an environment where there were considerable gradients of temperature, oxidation-reduction potential, and $\mathrm{pH}$. It appears that these gradients favored sharp separation of $\mathrm{Fe}$ and $\mathrm{Mn}$.

Deposition of $\mathrm{Fe}$, together with silica and moderate amounts of $\mathrm{Mg}$, in an environment with relatively high temperature, weakly oxidized values of $\mathrm{Eh}$, and rather acidic $\mathrm{pH}$ values resulted in formation of colloform, globular accumulations of disordered, mixed-layer phases of nontronite and celadonite. It is worth noting that $\mathrm{Fe}$-mica can be present in the initial stage as interlayers in rather low concentrations. The presence of celadonite patches in amygdales and veinlets of altered basalts of the basement; (Pertsev and Rusinov, 1980; Rusinov et al., 1980) suggests that relatively small amounts of celadonite can be regarded as initial components, synthesized from hydrothermal solutions. However, the formation of considerable amounts of celadonite is associated with postsedimentary alteration of nontronite components resulting from their interaction with interstitial solutions. It should be emphasized that during the early interactions between the hydrothermal solutions and weakly clayey siliceous-carbonate sediments, the latter were dissolved, while the green clays being formed were substantially contaminated with $\mathrm{SiO}_{2}, \mathrm{Al}_{2} \mathrm{O}_{3}, \mathrm{TiO}_{2}$, and other components. However, considerable amounts of relatively pure ferruginous layered silicates were then precipitated out of the solutions. Manganese hydroxides represented by todorokite (buserite) were precipitated from residual portions of hydrothermal solutions in environments with relatively low temperature and with $\mathrm{pH}$ and Eh values typical of bottom waters from areas with active volcanism. It is notable that among the samples of manganese-hydroxide crusts, manganate-todorokite (buserite) $(10 \AA)$ was identified, which-as compared to birnessite and $\delta-\mathrm{MnO}_{2}-$ is relatively weakly oxidized. The data of Corliss et al. (1978) show that manganesehydroxide crusts are composed predominantly of birnessite and possibly to a lesser extent todorokite. Thus, the development of todorokite (buserite) crusts, coating accumulations of ferruginous clays, provides evidence of a somewhat less oxidizing regime in the bottom waters compared to recent environments. This can result from an oxygen deficit stemming from massive hydrothermal emissions and correspondingly higher bottomwater temperatures as well as from high rates of pelagic sedimentation (about $50 \mathrm{~mm} / 10^{3} \mathrm{y}$.).

At the same time a significant role in the growth of crust-like accumulations of manganese hydroxides could 


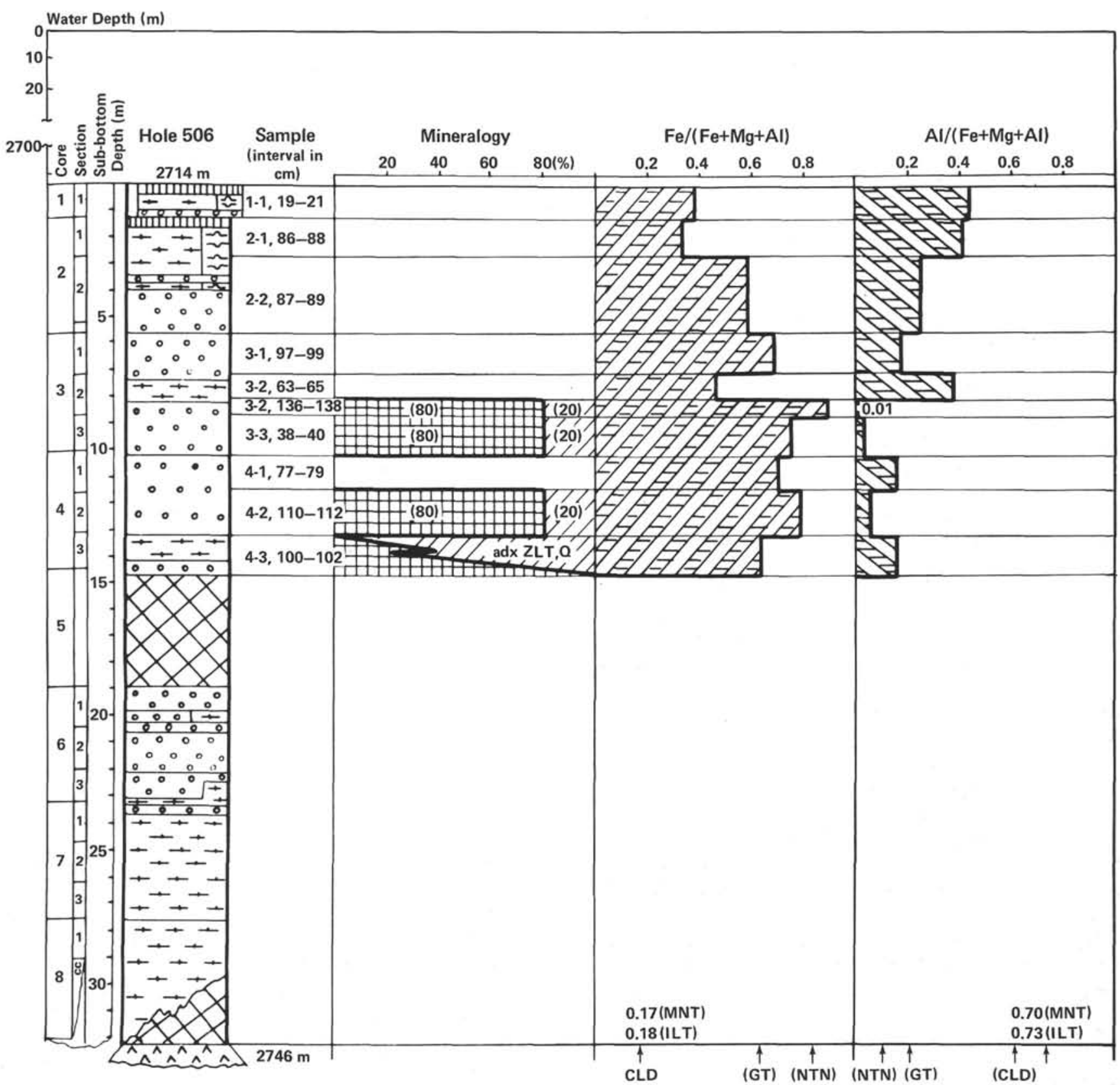

Figure 11. Distribution of the ratios $\mathrm{Fe} /(\mathrm{Fe}+\mathrm{Mg}+\mathrm{Al})$ and $\mathrm{Al} /(\mathrm{Fe}+\mathrm{Mg}+\mathrm{Al})$, Hole 506 .

Table 8. Chemical composition of upper Cenozoic sediments, Hole 506.

\begin{tabular}{|c|c|c|c|c|c|c|c|c|c|c|c|c|c|}
\hline No. & $\begin{array}{c}\text { Sample } \\
\text { (interval in } \mathrm{cm} \text { ) }\end{array}$ & $\mathrm{SiO}_{2}$ & $\mathrm{TiO}_{2}$ & $\mathrm{Al}_{2} \mathrm{O}_{3}$ & $\mathrm{Fe}_{2} \mathrm{O}_{3}$ & $\mathrm{MnO}$ & $\begin{array}{l}\mathrm{CaO} \\
\mathrm{t.} \% \text {; } \mathrm{ai}\end{array}$ & $\begin{array}{r}\mathrm{P}_{2} \mathrm{O}_{5} \\
\text {-dried) }\end{array}$ & $\mathrm{Na}_{2} \mathrm{O}$ & $\mathrm{K}_{2} \mathrm{O}$ & $\mathrm{MgO}$ & $\mathrm{BaO}$ & $\mathrm{SrO}$ \\
\hline 1 & $1-1,19-21$ & 12.41 & 0.08 & 2.50 & 1.70 & 1.46 & 41.08 & 0.15 & 2.81 & 0.34 & 0.85 & 0.30 & 0.25 \\
\hline 2 & $2-2,86-88$ & 10.21 & 0.07 & 1.67 & 1.04 & 0.29 & 45.20 & 0.10 & 2.20 & 0.30 & 0.84 & 0.260 & 0.26 \\
\hline 3 & $2-2,87-89$ & 33.41 & 0.22 & 5.54 & 9.99 & 0.14 & 13.72 & 0.12 & 6.27 & 1.41 & 3.06 & 0.54 & 0.11 \\
\hline 4 & $3-1,97-99$ & 42.50 & 0.23 & 5.52 & 17.04 & 0.11 & 1.00 & 0.10 & 7.48 & 1.99 & 4.11 & 0.594 & 0.03 \\
\hline 5 & $3-2,63-65$ & 15.75 & 0.15 & 3.80 & 3.45 & 0.17 & 37.32 & 0.09 & 3.29 & 0.55 & 1.40 & 0.283 & 0.21 \\
\hline 6 & $3-2,136-138$ & 47.11 & 0.014 & 0.38 & 28.35 & 0.08 & 0.70 & 0.02 & 2.17 & 2.73 & 3.69 & 0.05 & \\
\hline 7 & $3-3,38-40$ & 47.55 & 0.05 & 1.10 & 26.57 & 0.06 & 0.3 & 0.03 & 4.09 & 2.48 & 3.93 & 0.280 & 0.02 \\
\hline 8 & $4-1,77-79$ & 44.61 & 0.24 & 5.44 & 18.64 & 0.15 & 0.65 & 0.10 & 5.51 & 2.19 & 4.33 & 0.648 & 0.02 \\
\hline 9 & $4-2,110-112$ & 40.16 & 0.08 & 1.92 & 20.27 & 0.16 & 5.87 & 0.04 & 2.53 & 2.51 & 4.55 & 0.268 & 0.04 \\
\hline 10 & $4-3,100-102$ & 44.61 & 0.25 & 5.42 & 18.26 & 0.14 & 1.98 & 0.08 & 4.97 & 2.40 & 4.69 & 0.527 & 0.02 \\
\hline
\end{tabular}


Table 9. Chemical composition of upper Cenozoic sediments, Hole 506C.

\begin{tabular}{rlrlllllllllll}
\hline No. & $\begin{array}{c}\text { Sample } \\
\text { (interval in cm) }\end{array}$ & $\mathrm{SiO}_{2}$ & $\mathrm{TiO}_{2}$ & $\mathrm{Al}_{2} \mathrm{O}_{3}$ & $\mathrm{Fe}_{2} \mathrm{O}_{3}$ & $\mathrm{MnO}$ & $\begin{array}{c}\mathrm{MgO} \\
\text { (wt. \%; ; air-dried) }\end{array}$ & $\begin{array}{c}\mathrm{CaO} \\
\mathrm{P}_{2} \mathrm{O}_{5}\end{array}$ & $\mathrm{Na}_{2} \mathrm{O}$ & $\mathrm{K}_{2} \mathrm{O}$ & $\mathrm{BaO}$ & $\mathrm{SrO}$ \\
\hline 1 & $4-1,105-107$ & 48.86 & 0.007 & 0.44 & 29.47 & 0.03 & 3.84 & 0.50 & 0.03 & 2.69 & 2.88 & 0.014 & \\
2 & $4-2,41-43$ & 39.01 & 0.22 & 5.08 & 15.58 & 0.14 & 4.33 & 6.42 & 0.09 & 6.05 & 2.15 & 0.373 & \\
3 & $4-3,61-63$ & 47.85 & 0.018 & 0.69 & 27.16 & 0.04 & 4.58 & 0.00 & 0.03 & 3.18 & 3.05 & 0.055 & \\
4 & $5-1,122-124$ & 14.42 & 0.12 & 3.26 & 3.41 & 0.29 & 1.68 & 37.88 & 0.06 & 3.51 & 0.48 & & \\
5 & $5-2,113-115$ & 11.07 & 0.09 & 2.76 & 1.64 & 0.25 & 1.39 & 43.12 & 0.02 & 2.49 & 0.34 & 0.208 & \\
6 & $5-3,112-114$ & 14.66 & 0.27 & 3.82 & 3.43 & 0.20 & 1.67 & 40.35 & 0.05 & 2.69 & 0.41 & 0.18 & \\
7 & $6-1,80-82$ & 11.92 & 0.11 & 3.17 & 1.95 & 0.23 & 1.19 & 42.55 & 0.09 & 2.69 & 0.45 & 0.29 & 0.07 \\
8 & $6-2,80-82$ & 8.52 & 0.08 & 2.40 & 1.59 & 0.19 & 1.00 & 45.070 & 0.05 & 2.13 & 0.30 & 0.18 & 0.36 \\
9 & $6-3,80-82$ & 9.06 & 0.08 & 2.70 & 1.03 & 0.19 & 0.77 & 47.36 & 0.04 & 2.09 & 0.36 & 0.17 & \\
10 & $7-1,114-116$ & 9.00 & 0.11 & 2.87 & 1.64 & 0.36 & 0.89 & 46.22 & 0.06 & 2.10 & 0.37 & 0.22 \\
11 & $8-1,81-83$ & 45.01 & 0.04 & 0.85 & 27.02 & 0.20 & 3.57 & 4.31 & 0.04 & 2.17 & 2.69 & 0.059 & 0.02 \\
12 & $8-2,24-26$ & 24.98 & 0.52 & 6.34 & 7.77 & 0.27 & 3.00 & 30.96 & 0.12 & 2.02 & 0.48 & 0.165 & 0.129 \\
\hline
\end{tabular}

be played by a process of chemical sorption with autocatalysis oxidation of this metal sorbed from the bottom waters, enriched in manganese from the volcanic emissions (Weiss, 1977; Varentsov, 1980).

The main mass of $\mathrm{Fe}$ and $\mathrm{Mn}$ in the region studied was deposited during massive flux of hydrothermal solutions in the late Pleistocene. Postsedimentary transformation of the hydrothermal sediments led to their partial crystallization and, for the green clays, to a distinctly expressed celadonitization.

\section{GEOCHEMICAL ASSEMBLAGES}

Thus far, we have considered some aspects of the mineralogy and geochemistry of the major components of the hydrothermal and pelagic sediments recovered on Leg 70 . However, despite relatively detailed studies, the differences in behavior of some components (Fe, $\mathrm{Mn}$, $\mathrm{Ti}, \mathrm{Al}, \mathrm{Ba}, \mathrm{Si}$, etc.) and the role played by the hydrothermal constituents proper in the processes of sedimentation of this region remained unclear. To cast light on these problems, the paragenic assemblages of the major components, both in hydrothermal and pelagic deposits, were studied. It was assumed that such an approach might provide insight into formation of these sediments.

The available data were processed by computer (EC1022) in the Laboratory of Mathematic Methods of the Geological Institute of the USSR Academy of Sciences, using factor analysis: R- and Q-modes (Davis, 1973; Harman, 1967).

The distribution pattern of the constituents of the sediments, as revealed by our investigations, definitely displayed segregation of geochemical groups. Within the clusters the components are connected by relatively strong bonds. More detailed data on application of factor analysis are given elsewhere (Varentsov, 1980b).

Assemblage IA(+): $\mathrm{SiO}_{2}(0.92)-\mathrm{Fe}_{2} \mathrm{O}_{3}(0.94)-\mathrm{MgO}$ $(0.91)-\mathrm{P}_{2} \mathrm{O}_{5}(0.11)-\mathrm{Na}_{2} \mathrm{O}(0.53)-\mathrm{K}_{2} \mathrm{O}(0.96)$. Dispersion: $47.15 \%$.

This cluster of components plays an essential role in the chemical composition of sediments (Table 10). We have concluded that this assemblage is represented by relatively pure varieties of green hydrothermal clays (Fig. 12), composed of disordered, mixed-layer phases of Fe-mica (celadonite) and $\mathrm{Fe}$-smectite (nontronite). It is interesting to note that the relatively high factor scores $(>0.75)$ of this assemblage are observed predominantly in the upper part of upper Pleistocene se-
Table 10. Results of factor analysis (R-mode) of chemical components, upper Pleistocene deposits, Leg 70 (Holes 506, 506C, 507D, 507F, $507 \mathrm{H}, 509 \mathrm{~B})$.

\begin{tabular}{ccrrr}
\hline & & \multicolumn{3}{c}{$\begin{array}{c}\text { Factor loadings } \\
\text { (after rotation) }\end{array}$} \\
\cline { 3 - 5 } No. & Components & \multicolumn{1}{c}{$\mathrm{I}$} & \multicolumn{1}{c}{$\mathrm{II}$} & \multicolumn{1}{c}{ III } \\
\hline 1 & $\mathrm{SiO}_{2}$ & 0.92 & 0.12 & -0.12 \\
2 & $\mathrm{TiO}_{2}$ & -0.32 & 0.90 & 0.04 \\
3 & $\mathrm{Al}_{2} \mathrm{O}_{3}$ & -0.36 & 0.90 & 0.05 \\
4 & $\mathrm{Fe}_{2} \mathrm{O}_{3}$ & 0.94 & -0.13 & -0.05 \\
5 & $\mathrm{MnO}$ & -0.48 & 0.02 & 0.75 \\
6 & $\mathrm{MgO}$ & 0.91 & 0.05 & 0.05 \\
7 & $\mathrm{CaO}$ & -0.82 & 0.16 & 0.25 \\
8 & $\mathrm{P}_{2} \mathrm{O}_{5}$ & 0.11 & 0.51 & 0.64 \\
9 & $\mathrm{Na} 2 \mathrm{O}$ & 0.53 & 0.71 & 0.07 \\
10 & $\mathrm{~K}_{2} \mathrm{O}$ & 0.96 & -0.07 & 0.002 \\
11 & $\mathrm{BaO}$ & 0.06 & 0.63 & 0.15 \\
12 & $\mathrm{SrO}$ & -0.71 & 0.16 & 0.26 \\
Dispersion & Input & 47.15 & 24.50 & 7.08 \\
\multicolumn{2}{l}{ (\%) Cumulative } & 47.15 & 71.65 & 78.74 \\
\hline
\end{tabular}

quences in those holes drilled on the tops and slopes of hydrothermal mounds.

Assemblage IB(-): $\quad \mathrm{TiO}_{2}(-0.32)-\mathrm{Al}_{2} \mathrm{O}_{3}(-0.36)-$ $\mathrm{MnO}(-0.48)-\mathrm{CaO}(-0.82)-\mathrm{SrO}(-0.71)$

This assemblage is antipolar to IA(+) (see Table 10). It is represented by clay carbonate pelagic oozes. As was discussed earlier, the clay components of these oozes are composed of varieties of montmorillonite and illite. It is worth noting that the presence of $\mathrm{Mn}$ and $\mathrm{Sr}$ in this assemblage is interpreted as evidence that rather early on, low-temperature hydrothermal activity affected the carbonate sedimentation of this region. Foraminiferal-nannofossil oozes are enriched in $\mathrm{Mn}$ and $\mathrm{Sr}$ compared to the average composition of carbonate sediments in the ocean. At the present time, the bottom waters of this region have rather high concentrations of hydrothermal Mn (Weiss, 1977; Klinkhammer et al., 1977). Relatively high factor scores were noted in the lower part of the holes, drilled apart from the fault zones and traced by hydrothermal mounds or ridges (see Fig. 13). It is these intervals which contain relatively weakly altered, clayey carbonate pelagic oozes.

Assemblage IIA(+): $\mathrm{SiO}_{2}(0.12)-\mathrm{TiO}_{2}(0.90)-\mathrm{Al}_{2} \mathrm{O}_{3}$ $(0.90)-\mathrm{CaO}(0.16)-\mathrm{P}_{2} \mathrm{O}_{5}(0.51)-\mathrm{Na}_{2} \mathrm{O}(0.71)-\mathrm{BaO}(0.63)-$ Sr(0.16). Dispersion: $24.50 \%$. 
This assemblage contains components with relatively high values of factor loadings $(>0.50)$ : $\mathrm{TiO}_{2}-\mathrm{Al}_{2} \mathrm{O}_{3}-$ $\mathrm{P}_{2} \mathrm{O}_{5}-\mathrm{Na}_{2} \mathrm{O}-\mathrm{BaO}$. The nature of this component set and its distribution in the holes studied (Fig. 14) suggest that this cluster represents the residual (after dissolution) aluminosilicate, predominantly clayey matter, formed as a result of interaction between hydrothermal solutions and clayey carbonate pelagic oozes. If $\mathrm{TiO}_{2}, \mathrm{Al}_{2} \mathrm{O}_{3}$, and $\mathrm{P}_{2} \mathrm{O}_{5}$ can be properly regarded as residual components, then $\mathrm{BaO}$ is a hydrothermal component introduced by and associated with the aluminosilicate matter.

Maximum development of this group is observed in the upper part of the sequence within the intervals corresponding to accumulations of green hydrothermal clays (see Fig. 14; Holes 506, 506C, 507D, 507F, 509B) or within the equivalent intervals of the sequences composed of clay carbonate oozes (see Fig. 14; Hole 507H). The basal interval of this group occurring at the boundary with the basalt basement (see Fig. 14; Holes 506, 506C, 507D, 507F) is less expressed. Such a distribution of components reflects two stages of hydrothermal activity: (1) an early and relatively low-temperature stage, partially manifested in the lower part of the late Pleistocene and, as a rule, not accompanied by accumulation of green hydrothermal clays (mixed-layer phases of celadonite and nontronite), and (2) a later, relatively hightemperature stage with wide regional development and marked by accumulation of green hydrothermal clays.

Assemblage IIB(-): $\mathrm{Fe}_{2} \mathrm{O}_{3}(-0.13)-\mathrm{K}_{2} \mathrm{O}(-0.07)$

This group of components is antipolar to IIA(+). Lower values of factor loadings can be regarded as evidence of its relatively weak development. Comparing the data on sediment mineralogy with the set of components and their distribution suggests that the assemblage is represented by patches of Fe-hydroxides of dual origin: (1) the products of oxidation of green hydrothermal clays composed of celadonite and nontronite in a relatively weakly oxidizing environment, possibly near the sediment/water interface, and sulfides of carbonate pelagic oozes; (2) Fe-hydroxides precipitating from the residual hydrothermal solutions. The occurrence of relatively high factor scores $(>0.75)$ of this assemblage is limited as a rule by intervals of green hydrothermal clays (Holes 506, 506C, 506D, 507F, 509B) and, to a lesser extent, by the basal interval of carbonate sediments (Holes 507D, 507F).

Assemblage IIIA(+): $\mathrm{Mn}(0.75)-\mathrm{CaO}(0.25)-\mathrm{P}_{2} \mathrm{O}_{5}$ (0.64)- $\mathrm{BaO}(0.15)-\mathrm{Sr}(0.26)$. Dispersion: $7.08 \%$.

This assemblage is represented by manganese-hydroxide compounds; predominantly todorokite (buserite), closely associated with phosphates and such cations as $\mathrm{Ca}, \mathrm{Ba}$, and $\mathrm{Sr}$. Relatively high factor scores are distributed over the sequence rather unevenly. In Holes 506 and 507 they correspond to the intervals where accumulations of crust-like manganese hydroxides are abundant at the tops of the units of green hydrothermal clays, usually near the interface between sediment and bottom water. In Hole 509B, three intervals with high $(>0.75)$ factor scores are found in the upper part of late Pleistocene sediments, usually among accumulations of hydrothermal green clays (see Fig. 15). It should be emphasized that there are relatively higher factor scores in the basal part of the sequences of Holes 506C and 507F. This, along with other data, may indicate the initial lowtemperature manifestations of hydrothermal activity. The results of both field observations and experimental studies (see Dymond et al., 1980; Hekinian et al., 1980; Hoffert et al., 1980; Varentsov, 1980b; Varentsov and Stepanets, 1970) show that the accumulation of manganese hydroxides took place in environments with relatively low temperatures - as a rule, during the initial or final stages of hydrothermal processes.

\section{Hydrothermal Mineral Formation}

The paragenetic assemblages of components revealed by factor analysis correspond to the mineral phases observed in the deposits. The pattern of distribution of these assemblages reveals the dynamics of hydrothermal mineral formation during the late Pleistocene. The main characteristics of this process are the following:

1) Green hydrothermal clays composed of mixed-layers of celadonite and nontronite (Assemblage IA[+]) are hydrothermal products, reflecting a relatively hightemperature stage. The major components are $\mathrm{SiO}_{2}$, $\mathrm{Fe}_{2} \mathrm{O}_{3}, \mathrm{MgO}$, and $\mathrm{K}_{2} \mathrm{O}$; there is a peculiar absence of $\mathrm{Al}_{2} \mathrm{O}_{3}$ and $\mathrm{TiO}_{2}$. This group of components is most abundant in the upper part of the late Pleistocene near the fault zones and developed on the ocean floor in the form of hydrothermal mounds (see Fig. 12; Holes 506, $506 \mathrm{C}, 507 \mathrm{D}$, and 509B). However, the early indications of hydrothermal mineral formation are found in the lower part of the late Pleistocene near the basement contact (Hole 506C). It can be assumed that the sequence at Hole 509B (Fig. 12) also had a discontinuous, pulsating influx of highly ferruginous hydrothermal solutions. Three of its intervals show high factor scores of Assemblage IA $[+]$.

2) Manganese hydroxides and associated components $\left(\mathrm{P}_{2} \mathrm{O}_{5}, \mathrm{CaO}, \mathrm{BaO}\right.$, and $\left.\mathrm{SrO}\right)$ occur in the form of crusts and patches of todorokite (buserite) and are relatively low-temperature products of hydrothermal mineral formation (Assemblage IIIA[+]). They are localized in the uppermost hydrothermal accumulations, near the interface of the sediment and the seawater (see Fig. 15; Holes 506, 507D, 509B). Relatively early manifestations of this assemblage occur in the lower part of the sequence near the basement contact (see Fig. 15; Holes 506C and 507F). These data can be interpreted as evidence for relatively low-temperature mineral formation, which took place during the early stages of hydrothermal activity as well as in its final stage, when manganese hydroxides were precipitated out of the residual portions of hydrothermal solutions.

3) Studies of the development of hydrothermal mineral formation require assessment of composition and of the distribution features of residual products formed by interaction of hydrothermal solutions and weakly siliceous, carbonate pelagic oozes. The existence of such interaction is obvious, for observations under the microscope show the remains of siliceous skeletons of diatoms and radiolarians replaced by green clay matter. In addition, the relatively higher values of the $\mathrm{Al} /(\mathrm{Fe}+\mathrm{Mg}$ $+\mathrm{Al}$ ) ratio, exceeding 0.01 to 0.1 can also be interpreted as evidence for such processes. 


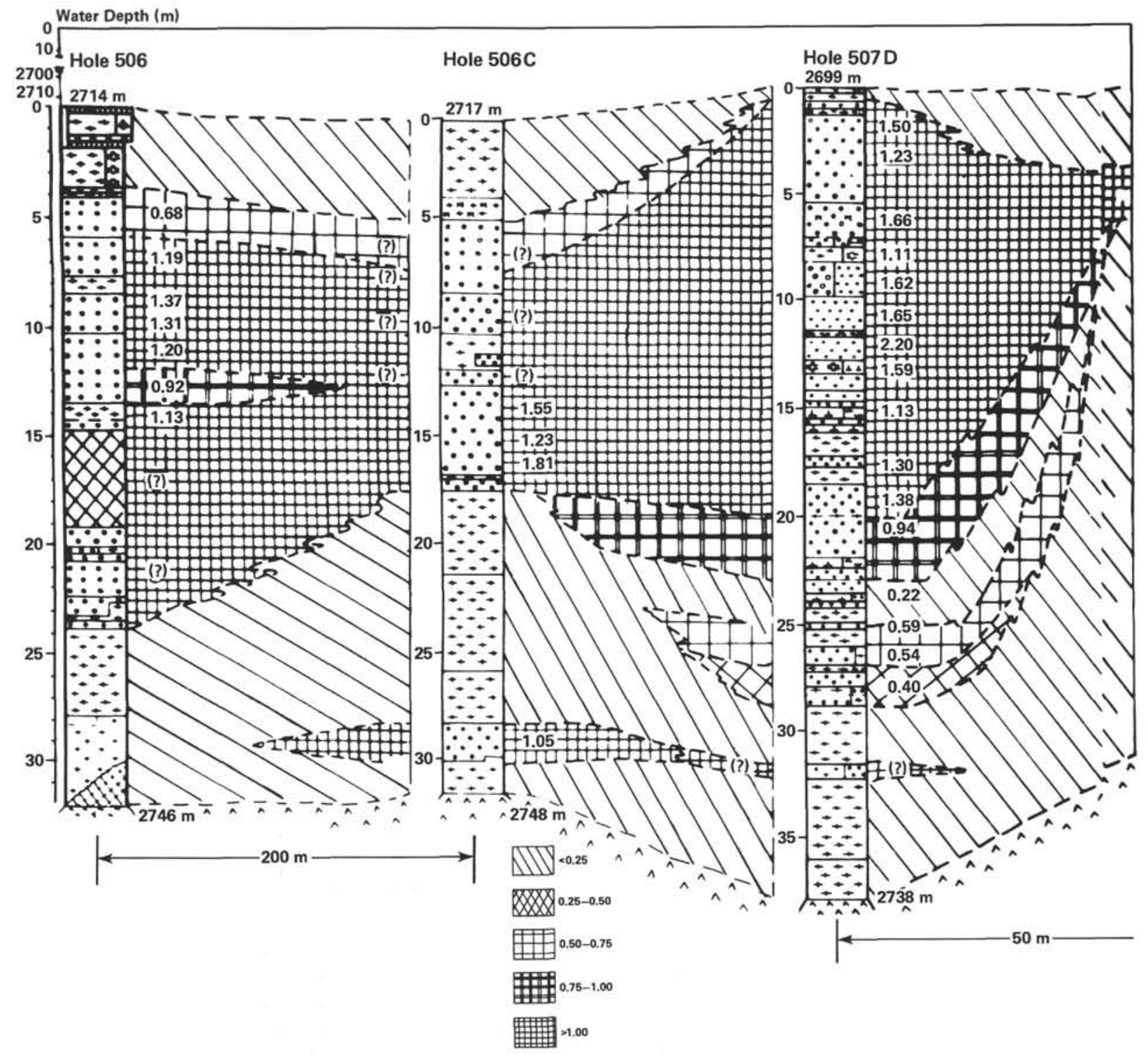

Figure 12. Distribution of factor assemblage IA(+) (green hydrothermal clays, composed of mixed-layer phases of celadonite and nontronite) in upper Pleistocene sequences in the Galapagos Rift Zone.

Paragenetic assemblage IIA(+) $\left(\mathrm{TiO}_{2}-\mathrm{Al}_{2} \mathrm{O}_{3}-\mathrm{P}_{2} \mathrm{O}_{5^{-}}\right.$ $\mathrm{Na}_{2} \mathrm{O}-\mathrm{BaO}$ ) is represented by residual products of interaction between hydrothermal solutions and siliceousclayey carbonate pelagic oozes (see Table 10, Fig. 14).

Distribution of this cluster actually reflects the general development of mineral products of hydrothermal origin: both high- and low-temperature products (Assemblage IA $[+]$ and IIIA $[+])$. At the same time, the distribution of assemblage IIA(+) shows the existence of two main stages in hydrothermal activity of this region: (1) in the lower part of the late Pleistocene, and (2) in the upper part of the late Pleistocene.

\section{CONCLUSIONS FOR FACTOR ANALYSIS OF MAJOR COMPONENTS}

Computer processing of chemical data using factor analysis revealed paragenetic assemblages of compo- nents. The distribution of these assemblages shows that the process of hydrothermal mineral formation proceeded in two stages: (1) an initial stage (early part of the late Pleistocene; and (2) a main relatively high temperature stage (late part of the late Pleistocene). The green clays (mixed-layer phases of celadonite and nontronite), corresponding to factor assemblage IA(+), were formed predominantly during the main stage. The manganese hydroxides and the associated components $(\mathrm{Ca}, \mathrm{Ba}, \mathrm{Sr}, \mathrm{P})$-Assemblage IIIA(+)-were accumulated mainly during the early stage and at the end of the main stage from relatively low-temperature, residual hydrothermal solutions, after the deposition of Fe. The distribution of residual products, formed by interaction of hydrothermal solutions and clayey-siliceous carbonate pelagic sediments, emphasizes the existence of two stages in hydrothermal activity and its regional stability. 


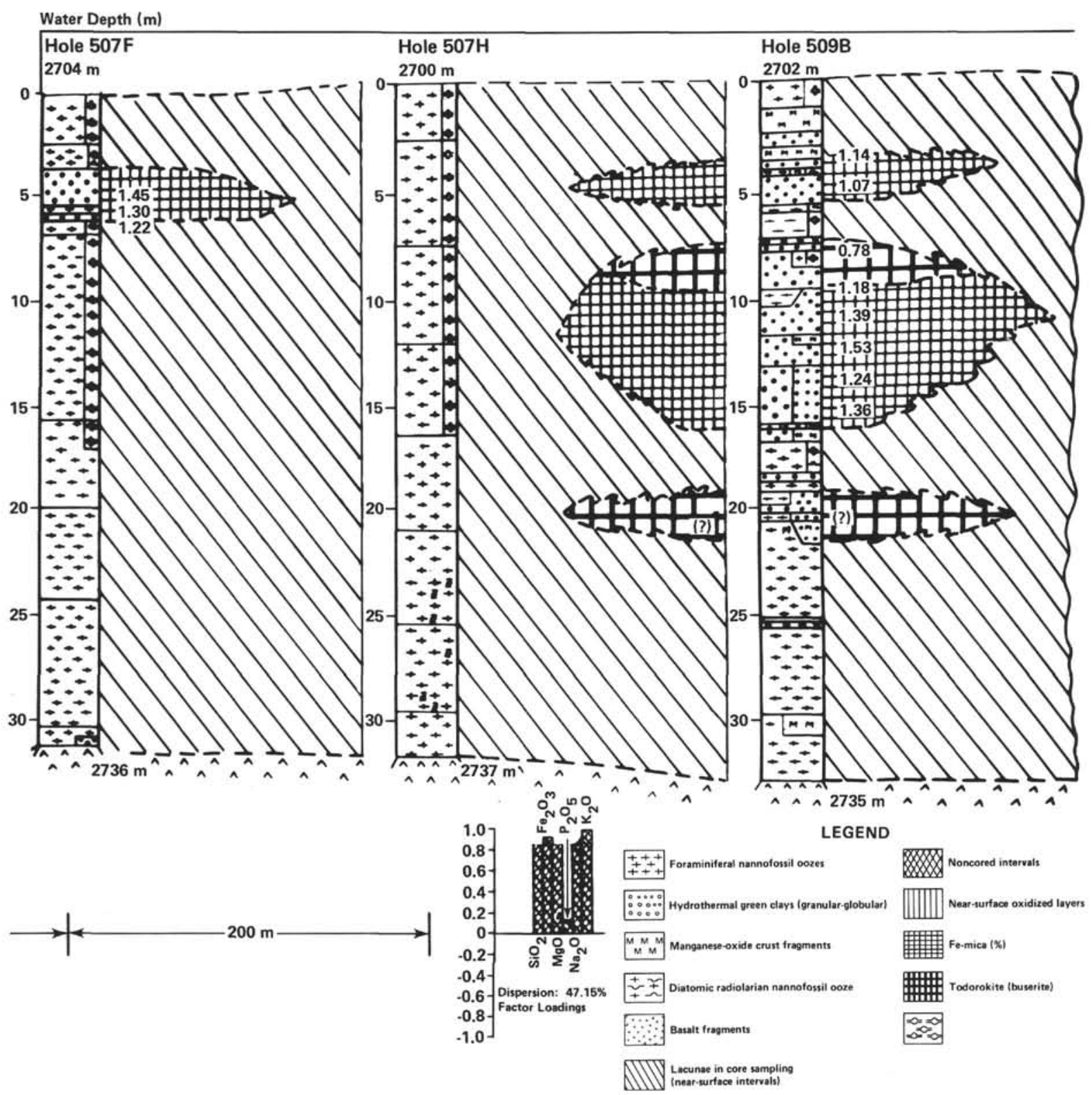

Figure 12. (Continued).

\section{ACKNOWLEDGMENTS}

We are very grateful to A. A. Migdisov (Institute of Geochemistry and Analytical Chemistry of the USSR Academy of Sciences) for providing the core samples.

For their assistance in analyzing the mineralogy and geochemistry of sediment components, we thank our colleagues at the Geological Institute of the USSR Academy of Sciences: N. I. Kartochkina and N. Yu. Vlasova for their help in processing the data, and preparing the materials, and N. D. Serebryannikova and E. V. Pokrovskaya for their assistance in the scanning electron microscope study.

With regard to the work on chemical assemblages, we thank D. A. Kazimirov (Laboratory of Mathematic Methods), N. I. Kartoshkina, and N. Yu. Vlasova for help in mathematical processing of data and preparation of material for publication.

We also are grateful to G. N. Surovtseva, I. G. Sheremet, and G. V. Kozlovskaya for English translation, and to V. S. Zelinsky, N. K. Mirskaya, and E. I. Pyatigorskaya for graphic presentation. Critical review of the chapter and comments by N. G. Brodskaya and A. G. Kossovskaya were useful and improved the work.

\section{REFERENCES}

Abbey, S., 1980. Studies in "standard samples" for use in the general analysis of silicate rocks and minerals. Geostandards Newsletter, 4(2):163-190.

Bailey, S. W., Brindley, G. W., Kodama, H., and Martin, R. T., 1979. Report of the Clay Minerals Society Nomenclature Committee for 1977 and 1978. Clays Clay Miner., 27:238-239.

Berenshtein, L. E., Masalovich, N. S., et al., 1979. Methodological principles of quality control of analytical work. In Ostroumov, G. V. (Ed.), Methodological Principles of Investigation of Chemical Composition of Rocks, Ores and Minerals: Moscow (Nedra), p. 30.

Bishoff, J. L., 1969. Red Sea geothermal brine deposits: Their mineralogy, chemistry, and genesis. In Degens, E. T., and Ross, D. A. (Eds.), Hot Brines and Recent Heavy Metal Deposits in the Red Sea. New York (Springer-Verlag), pp. 368-406.

Bishoff, J. L., and Dickson, F. W., 1975. Seawater-basalt interaction at $200^{\circ} \mathrm{C}$ and 500 bars: Implication for origin of seafloor heavy 


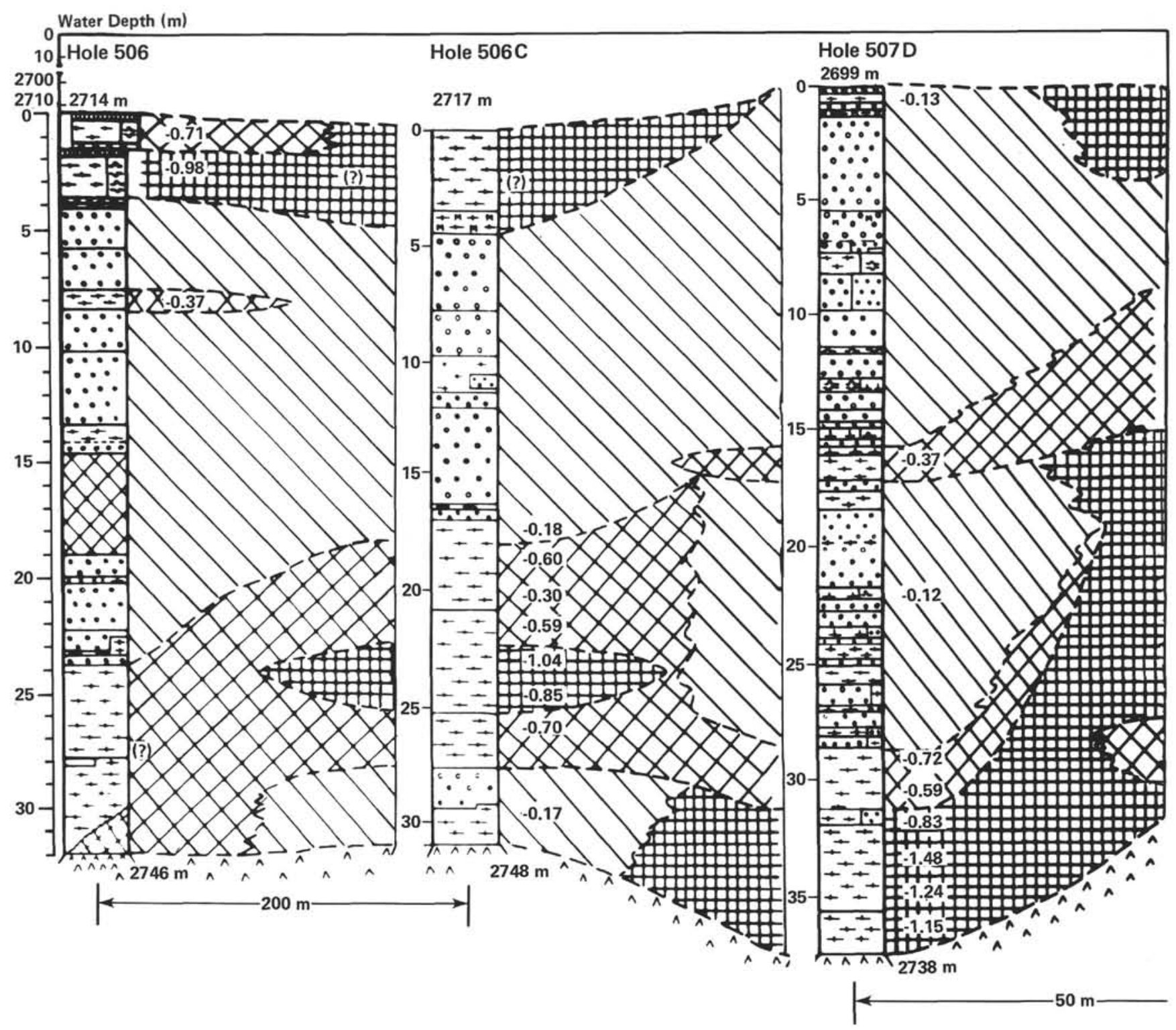

Figure 13. Distribution of factor assemblage IB(-) (clayey carbonate pelagic oozes) in upper Pleistocene sequences in the Galapagos Rift Zone.

metal deposits and regulation of seawater chemistry. Earth Planet. Sci. Lett., 25:385-397.

Buckley, H. A., Bevan, J. C., Brown, K. M., Johnson, L. R., and Farmer, V. C., 1978. Glauconite and celadonite: Two separate mineral species. Mineral. Mag., 42:373-382.

Butuzova, G. Yu., Drits, V. A., Lisitzina, N. A., Tsipursky, S. J., and Dmitrik, A. L., 1979. Dynamics of clay minerals formation in metalliferous sediments of Atlantis II Deep (Red Sea). Lithol. Mineral. Resourc., 1:30-42. (Russian)

Corliss, J. B., Lyle, M., and Dymond, J., 1978. The chemistry of hydrothermal mounds near the Galapagos Rift. Earth Planet. Sci. Lett., 40:12-24.

Davis, J. C., 1973. Statistics and Data Analysis in Geology: New York (Wiley and Sons).

Donnelly, T. W., 1980. Secondarily modified sediments of the Eastern Pacific: Major-element chemistry of Sites 420, 424, and 425, Deep Sea Drilling Project Leg 54. In Rosendahl, B. R., Hekinian, R. et al., Init. Repts. DSDP, 54: Washington (U.S. Govt. Printing Office), 329-338.

Drits, V. A., and Sakharov, B. A., 1976. X-ray structural analysis of mixed-layer minerals. Trans. Geol. Inst. AN SSSR, 295:1-256.
Dymond, J., Corliss, J. B., Cobler, R., Muratli, C. M., Chou, C., and Conard, R., 1980. Composition and origin of sediments recovered by deep sea drilling of sediment mounds, Galapagos Spreading Center. In Rosendahl, B. R., Hekinian, R., et al., Init. Repts. DSDP, 54: Washington (U.S. Govt. Printing Office), 377-386.

Frenzel, G., 1980. The manganese ore minerals. Geology and Geochemistry of Manganese, General Problems (Mineralogy, Geochemistry, Methods) (Vol. 1): Budapest (Publishing House of the Hungarian Academy of Sciences [Akadémiai Kiadó]), 25-158.

Giovanoli, R., 1980. On natural and synthetic manganese nodules. Geology and Geochemistry of Manganese, General Problems (Mineralogy, Geochemistry, Methods) (Vol. 1): Budapest (Publishing House of the Hungarian Academy of Sciences [Akadêmiai Kiadó]), pp. 159-202.

Harman, H. H., 1967. Modern Factor Analysis: Chicago (University of Chicago Press), p. 474.

Hekinian, R., Rosendahl, B., and Natland, J. H., 1980. Ocean crust geothermal process: A perspective from the vantage of Leg 54 drilling. In Rosendahl, B. R., Hekinian, R., et al., Init. Repts. DSDP, 54: Washington (U.S. Govt. Printing Office), 395-422. 


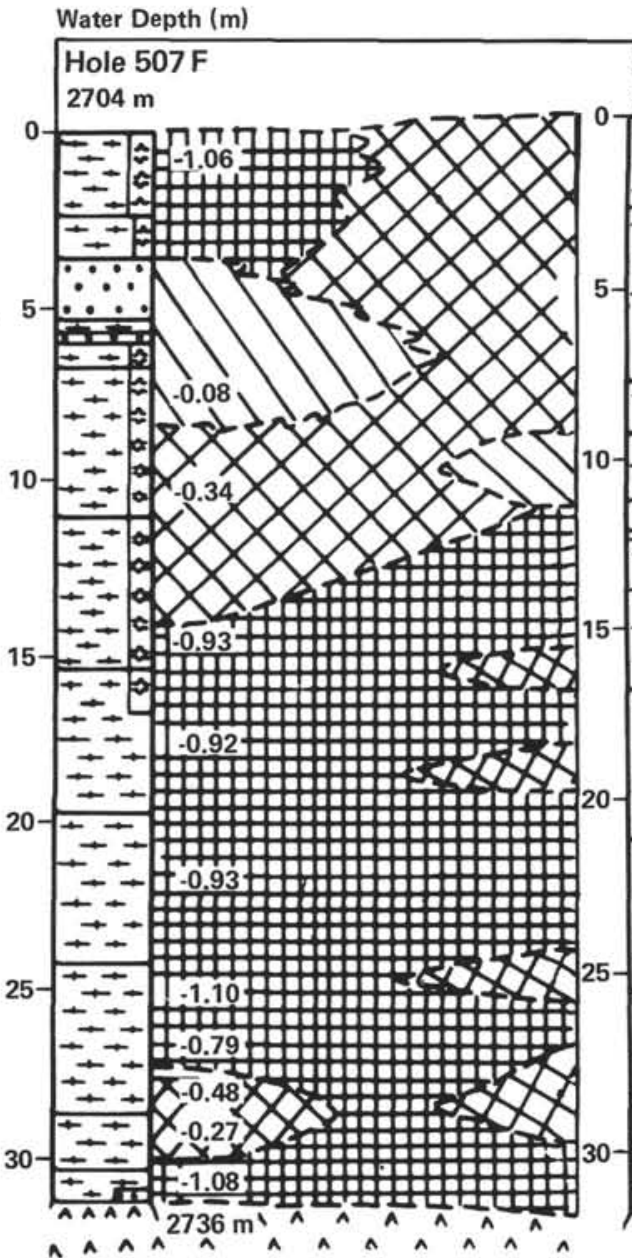

Hole $507 \mathrm{H}$

$2700 \mathrm{~m}$
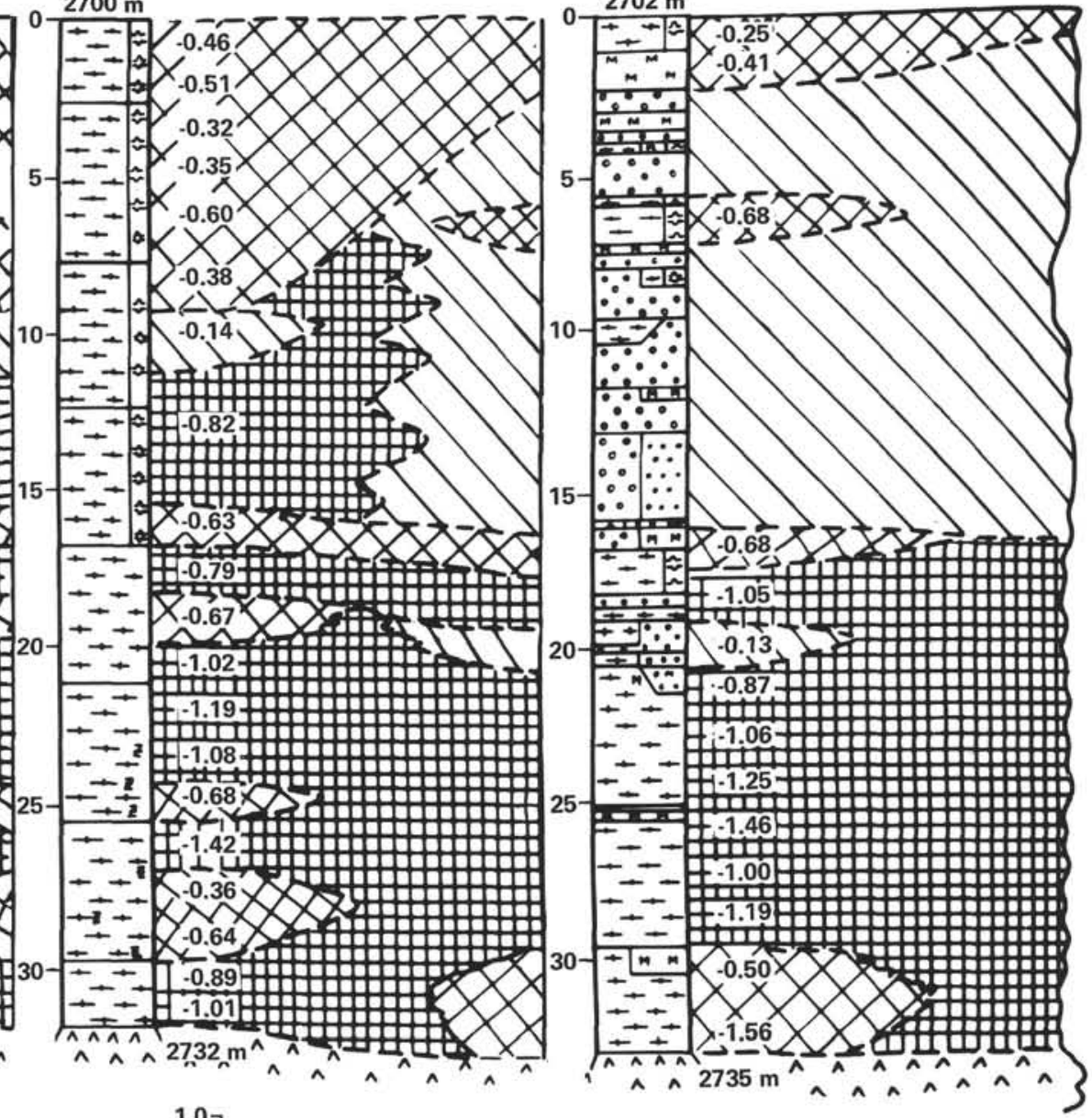

Hole 509B

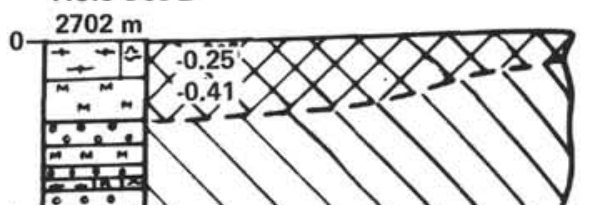

1

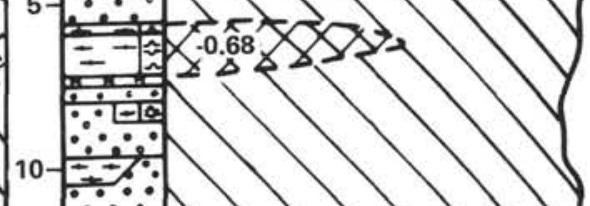

$\underbrace{10}_{15}$
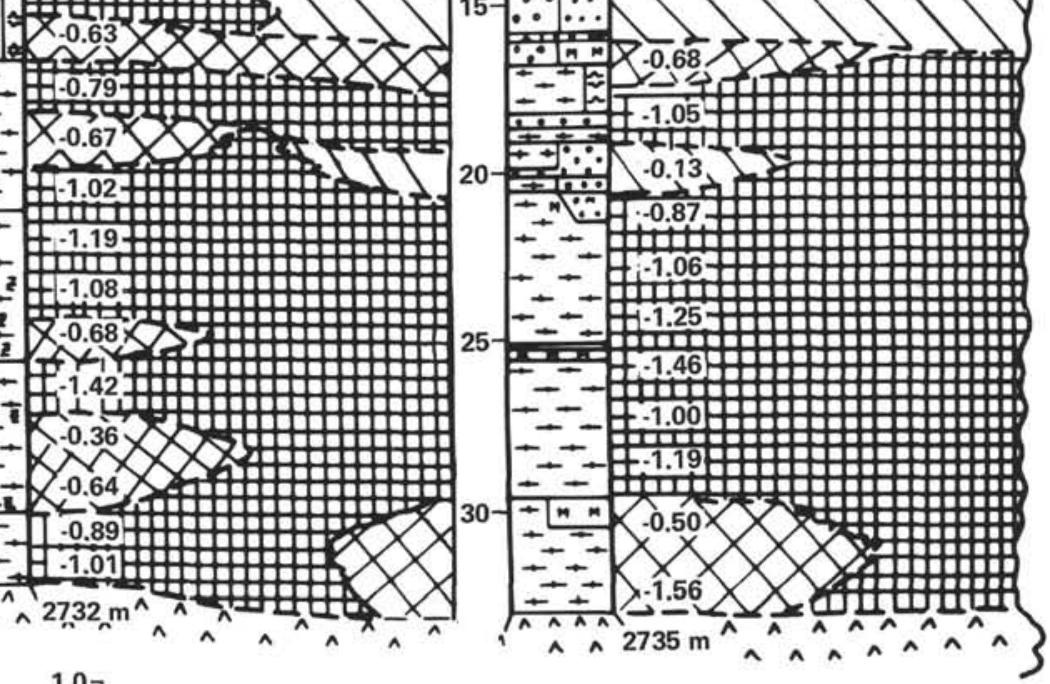

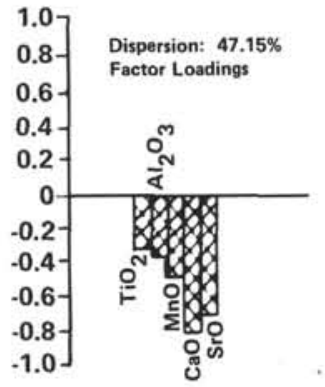

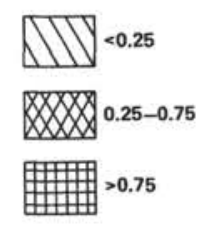

Figure 13. (Continued).

Hoffert, M., Person, A., Courtois, C., Karpoff, A. M., and Trauth, D., 1980. Sedimentology, mineralogy and geochemistry of hydrothermal deposits from Holes 424, 424A, 424B, and 424C (Galapagos Spreading Center). In Rosendahl, B. R., Hekinian, R., et al., Init. Repts. DSDP, 54: Washington (U.S. Govt. Printing Office), 339-376.

Humphris, S. E., and Hallman, C. M., 1980. Chemistry of interstitial waters sampled during Leg 54. In Rosendahl, B. R., Hekinian, R., et al., Init. Repts. DSDP, 54: Washington (U.S. Govt. Printing Office), 387-393.

Kerr, P. F., 1950. Analytical data on reference clay minerals. Prelim. Rept. 7, Reference Clay Minerals: New York (Am. Petrol. Inst.)

Klinkhammer, G., Bender, M., and Weiss, R. F., 1977., Hydrothermal manganese in the Galapagos Rift. Nature, 269(5626):319-320.

Lonsdale, P., 1977. Deep-tow observations at the mounds abyssal hydrothermal field, Galapagos Rift. Earth Planet. Sci. Lett., 36: 92-110.
Mottl, M. J., and Holland, H. D., 1978. Chemical exchange during hydrothermal alteration of basalt by seawater-I. Experimental results for major and minor components of seawater. Geochim. Cosmochim. Acta, 42:1103-1115.

Mottl, M. J., Holland, H. D., and Corr, R. F., 1979. Chemical exchange during hydrothermal alteration of basalt by seawater-II. Experimental results for $\mathrm{Fe}, \mathrm{Mn}$ and sulphur species. Geochim. Cosmochim. Acta, 43:869-884.

Pertsev, N. N., and Rusinov, V. L., 1980. Mineral assemblages and processes of alteration in basalts at Deep Sea Drilling Project Sites 417 and 418. In Donnelly, T., Francheteau, J., Bryan, W., Robinson, P., Flower, M., Salisbury, M., et al., Init. Repts. DSDP, $51,52,53$, Pt. 2: Washington (U.S. Govt. Printing Office), 12191242 .

Rateev, M. A., Timofeev, P. P., and Rengarten, N. V., 1980. Minerals of the clay fraction in Pliocene-Quaternary sediments of the east equatorial Pacific. In Rosendahl, B. R., Hekinian, R., et al., Init. 


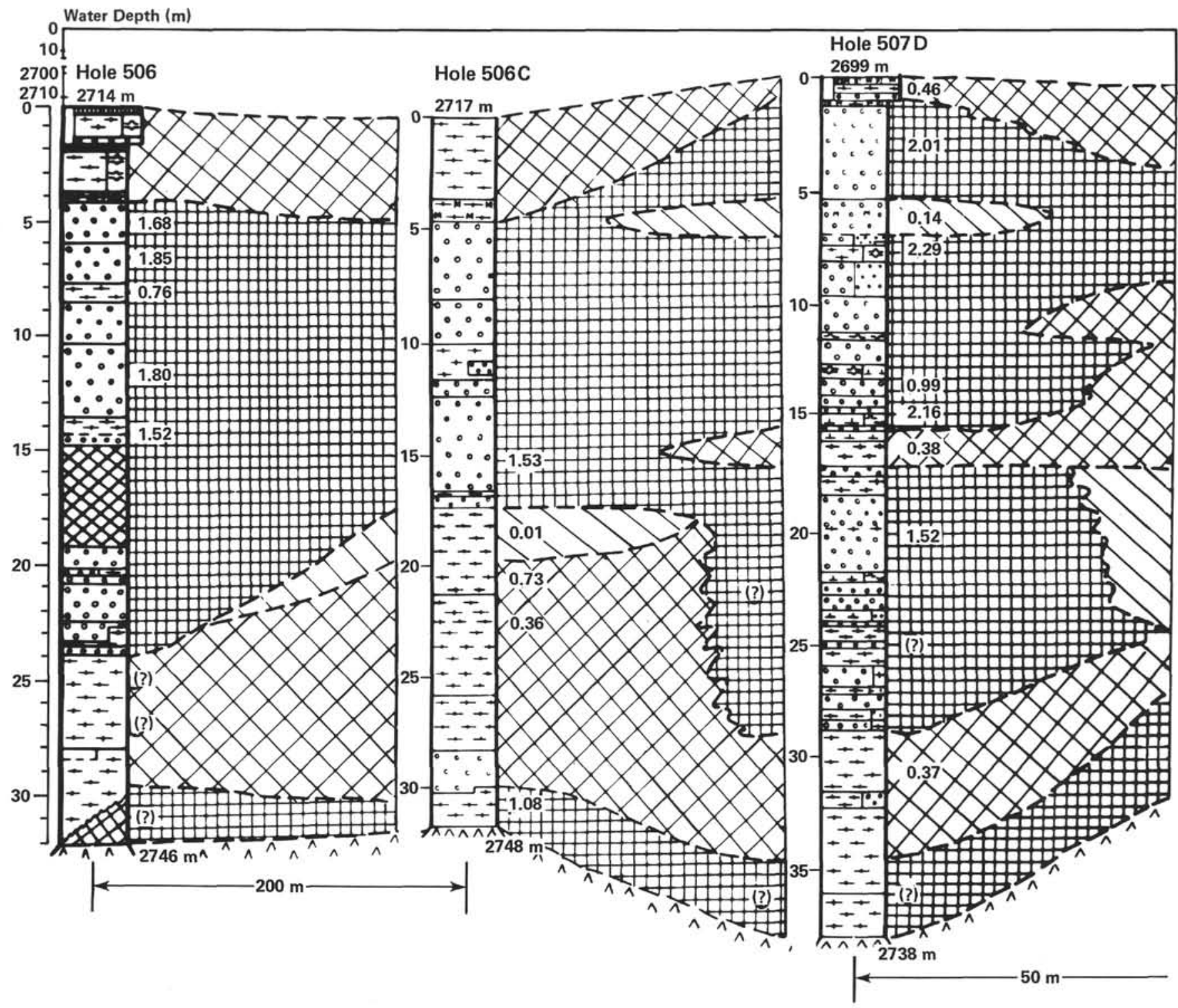

Figure 14. Distribution of the factor assemblage IIA(+) (aluminosilicate, predominantly clayey matter remaining after hydrothermal dissolution) in upper Pleistocene sequences in the Galapagos Rift Zone.

Repts. DSDP, 54: Washington (U.S. Govt. Printing Office), 307318.

Rusinov, V. L., Laputina, I. P., Muravitskaja, G. N., Zvjagin, B. B., and Gradusov, B. P., 1980. Clay minerals in basalts from Deep Sea Drilling Project Sites 417 and 418. In Donnelly, T., Francheteau, J., Bryan, W., Robinson, P., Flower, M., Salisbury, M., et al., Init. Repts. DSDP, 51, 52, 53, Pt. 2: Washington (U.S. Govt. Printing Office), 1265-1271.

Schrader, E. L., Furbish, W. J., Mattey, D., and May, J. A., 1980. Geochemistry and carbonate petrology of selected sediment samples from Deep Sea Drilling Project Leg 54, Eastern Pacific. In Rosendahl, B. R., Hekinian, R., et al., Init. Repts. DSDP, 54: Washington (U.S. Govt. Printing Office), 319-328.

Seyfried, W. E., and Bishoff, J. L., 1977. Hydrothermal transport of heavy metals by seawater: The role of seawater/basalt ratio. Earth Planet. Sci. Lett., 34:71-77.

Seyfried, W. E., and Mottl, M. J., 1977. Origin of submarine metalrich hydrothermal solutions: Experimental basalt-seawater interaction in a seawater-dominated system at $300^{\circ} \mathrm{C}, 500$ bars. Proc. 2nd. Int. Sym. Water-Rock Interaction, Sect. 4 (Strasbourg), pp. 173-180.
Tsipursky, S. J., Drits, V. A., and Chekin, S. S., 1978. The investigation of structural ordering of nontronite by the electron diffraction method of oblique textures. Proc. USSR Acad. Sci., Geol. Ser., 10:105-113.

Turekian, K. K., and Wedepohl, K. H., 1961. Distribution of the elements in some major units of the Earth's crust. Bull. Geol. Soc. Am., 72(2):175-190.

Varentsov, I. M., 1971. On the leaching of manganese in the course of interaction of basic volcanic materials with seawater. Soc. Min. Geol. Japan (Spec. Issue), 3:466-473.

, 1978. The geochemistry of heavy metals in upper Cenozoic sediments near the crest of the Mid-Atlantic Ridge, latitude $23^{\circ} \mathrm{N}$, drilled on DSDP Leg 45. In Melson, W. G., Rabinowitz, P. D., et al., Init. Repts. DSDP, 45: Washington (U.S. Govt. Printing Office), 349-377.

1980a. Geochemistry of transition metals in the processes of ferromanganese ore formation in Recent basins. Geology and Geochemistry of Manganese, General Problems (Mineralogy, Geochemistry, Methods) (Vol. 1): Budapest (Publishing House of the Hungarian Academy of Sciences [Akademiai Kiado]), pp. 367-387. 


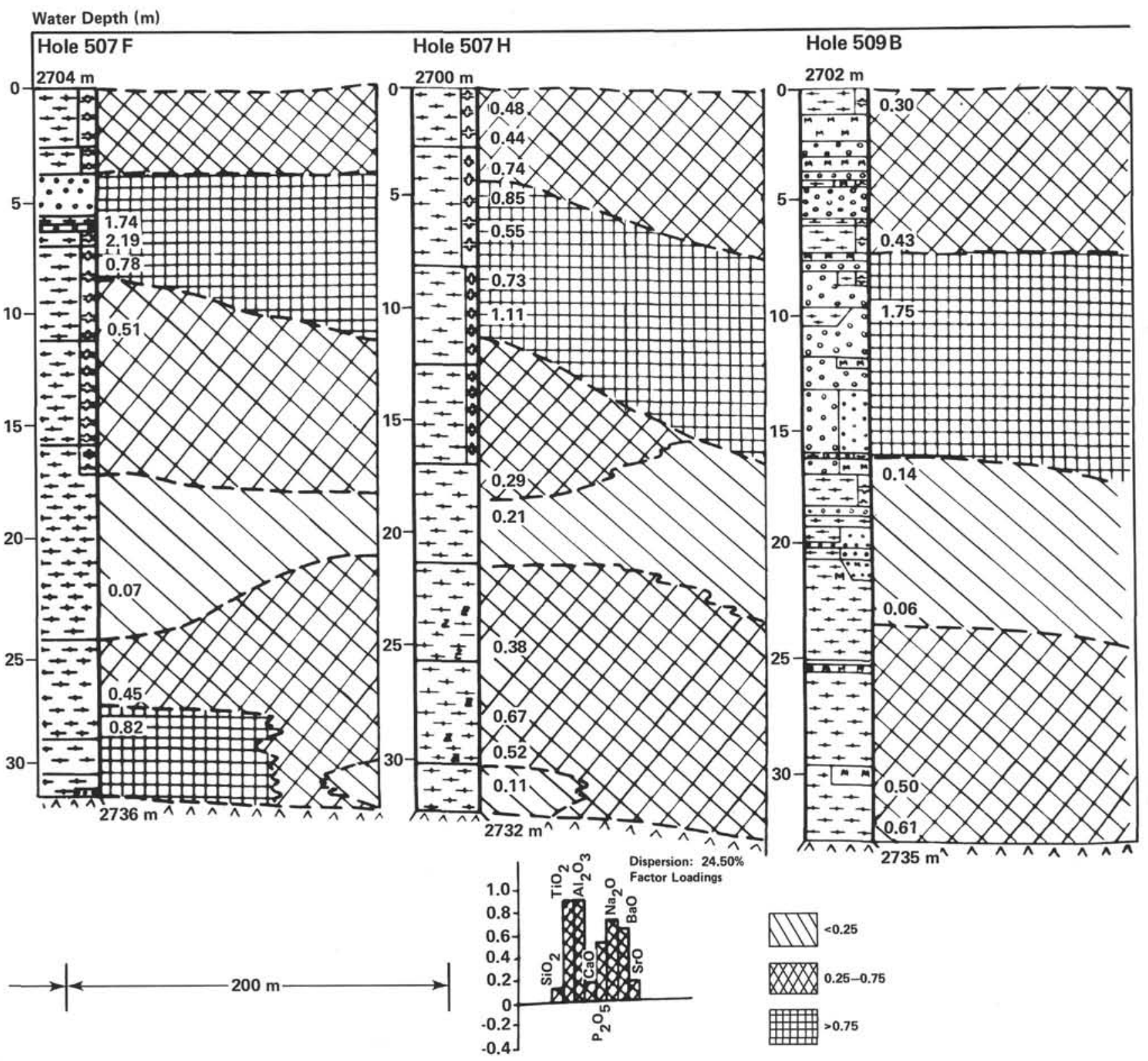

Figure 14. (Continued).

1980b. Metalliferous sediments of the North Atlantic: Geochemistry, peculiar features of their formation. Marine Geology, Sedimentology, Sedimentary Petrography and Geology of Ocean). Int. Geol. Cong., XXVI Session, Reports of Soviet Geologists: Leningrad (Nedra), 29-42. (Russian)

Varentsov, I. M., and Stepanets, M. I., 1970. The experiments on modelling of the processes of manganese leaching by seawater from basic volcanic materials. Dokl. Akad. Nauk SSSR, 190(3): 679-682. (Russian)

Walsh, J. N., 1980. The simultaneous determination of the major, minor and trace constituents of silicate rocks using inductively coupled plasma spectrometry. Spectrochim. Acta, 33B, 107-111.
Weaver, C. E., and Pollard, L. D., 1973. The chemistry of clay minerals Dev. Sedimentol., No. 15: Amsterdam (Elsevier), p. 213.

Weiss, R. F., 1977. Hydrothermal manganese in the deep-sea: Scavenging residence time and $\mathrm{Mn} /{ }^{3} \mathrm{He}$ relationships. Earth Planet, Sci. Lett., 37:257-262.

Wise, W. S., and Eugster, H. P., 1964. Celadonite: Synthesis, thermal stability and occurrences. Am. Mineral., 49:1031-1083.

Zvyagin, B. B., 1964. Electronography and Structural Crystallography of Clay Minerals: Moscow (Nauka). 


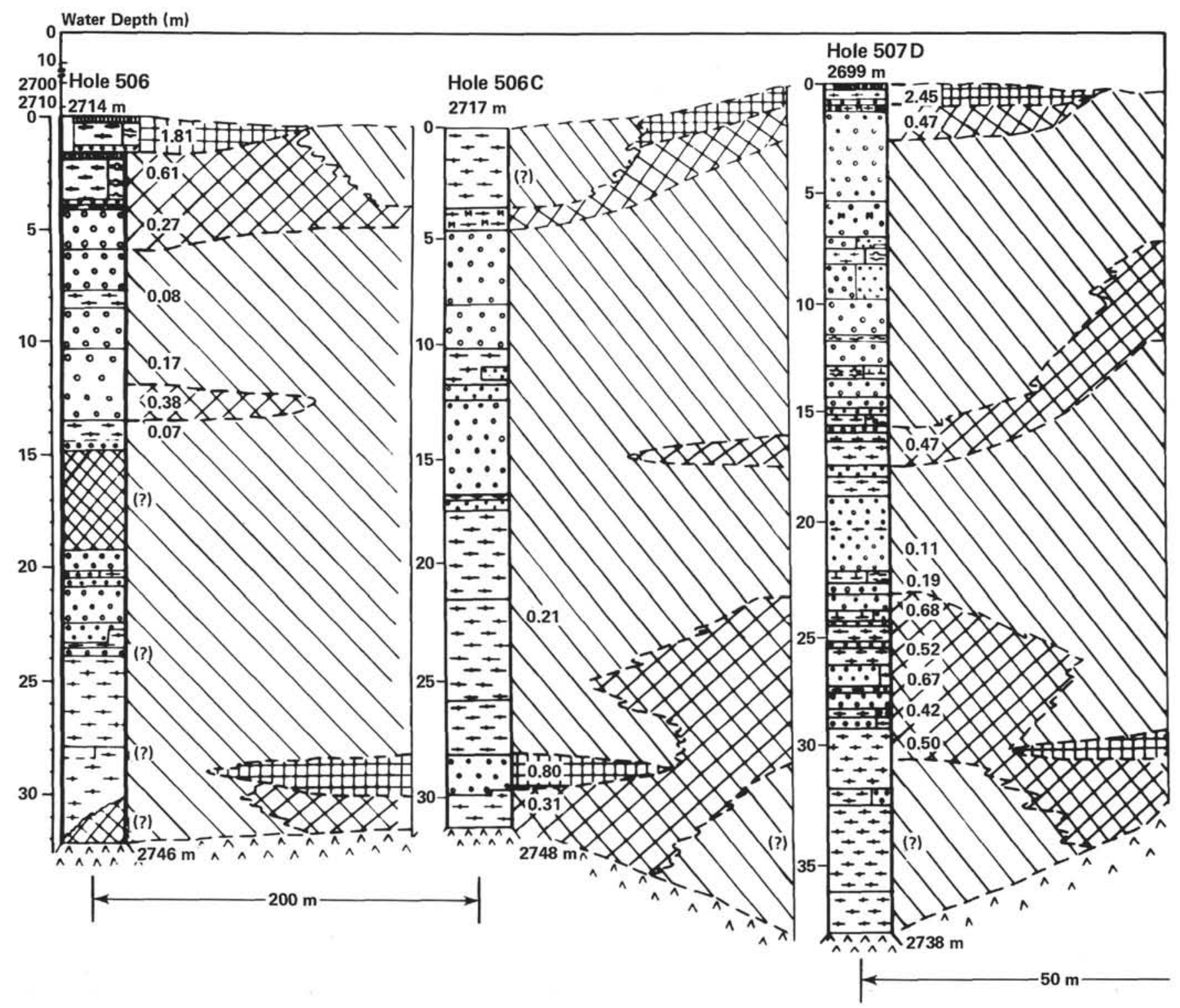

Figure 15. Distribution of factor assemblage IIIA(+) (manganese hydroxides, predominantly todorokite [buserite]) in upper Pleistocene sequences in the Galapagos Rift Zone. 


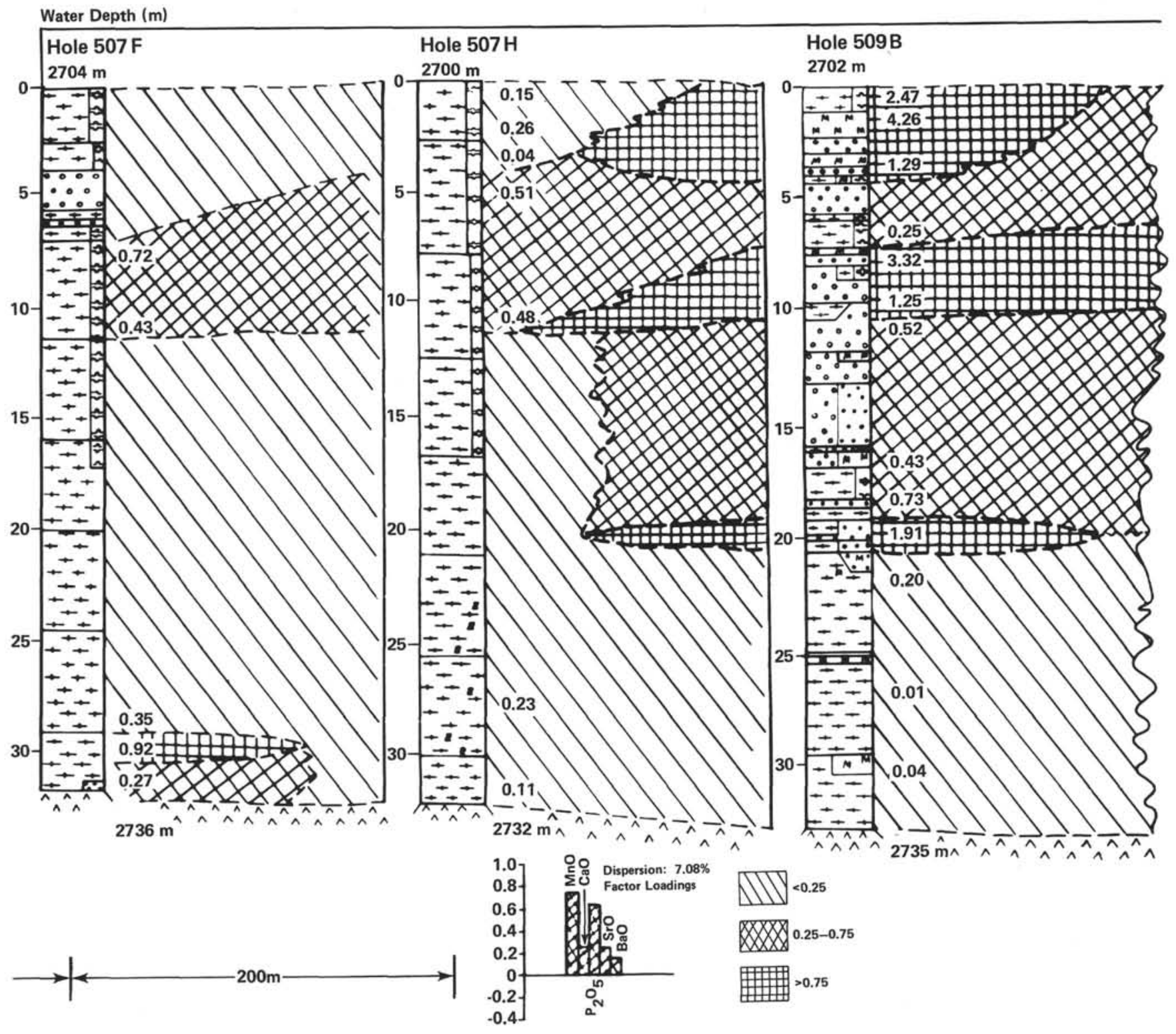

Figure 15. (Continued). 

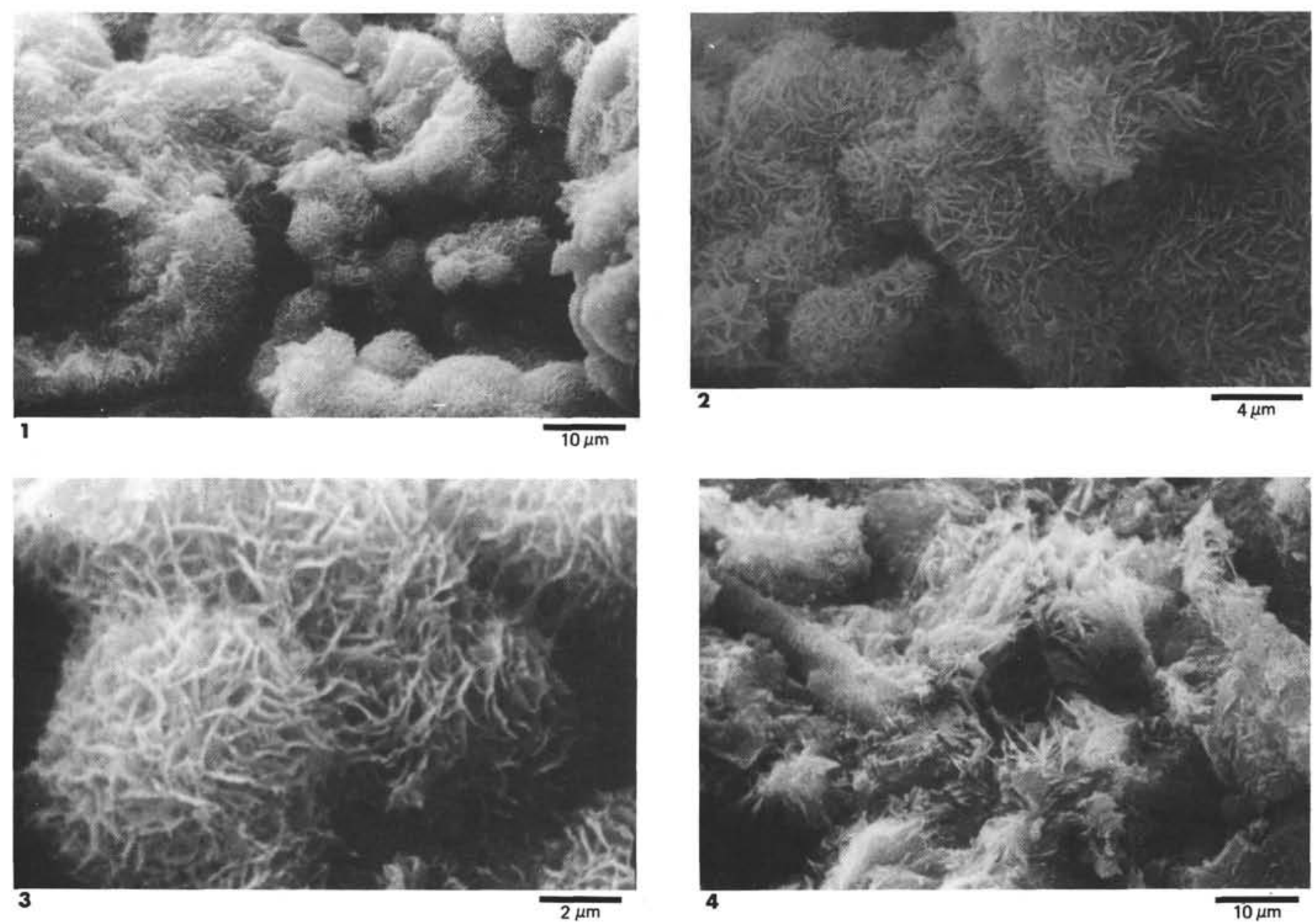

Plate 1. Scanning electron microscope photomicrographs of fragments of crust-like accumulations of manganese hydroxides in the form of todorokite (buserite), Sample 509B-1-2, 65-67 cm. 1-3. Increased magnification shows pronounced microglobular texture with development of finest acicular-foliaceous crystals on globular surface. 4. Acicular crystals of todorokite filling cavities in the crust fragments. 

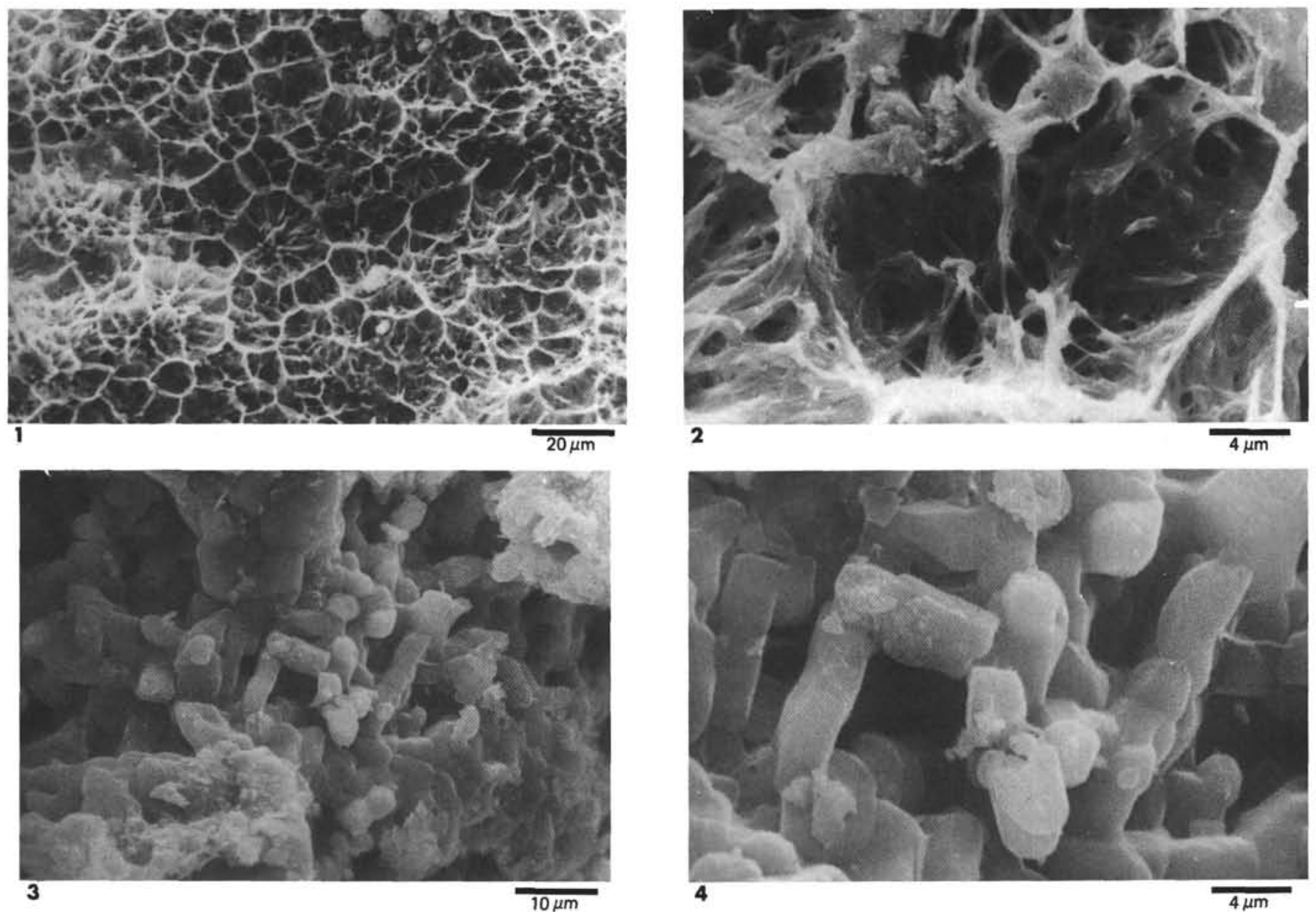

Plate 2. Scanning electron microscope photomicrographs of fragments of crust-like accumulations of manganese hydroxides, predominantly in the form of todorokite (buserite), Sample 509B-3-1, 58-60 cm. 1-2. Section of cellular-honeycomb textures of manganese hydroxides. 3-4. Increased magnification shows accumulation of prismatic crystals of todorokite (buserite) filling a cavity in the groundmass. 


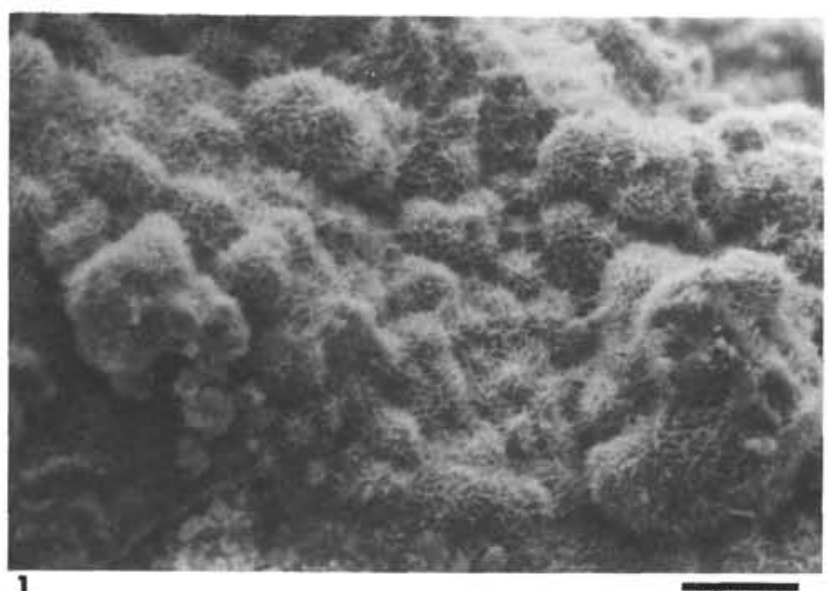

1

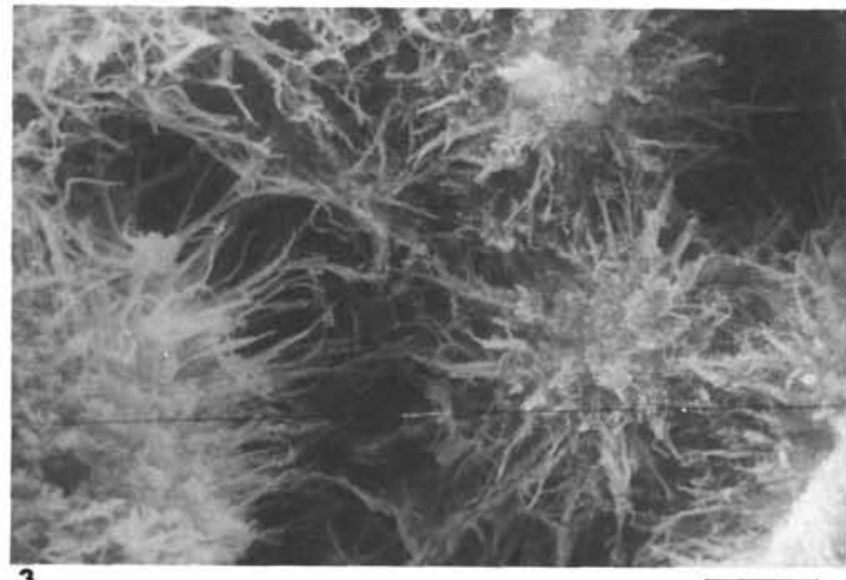

3
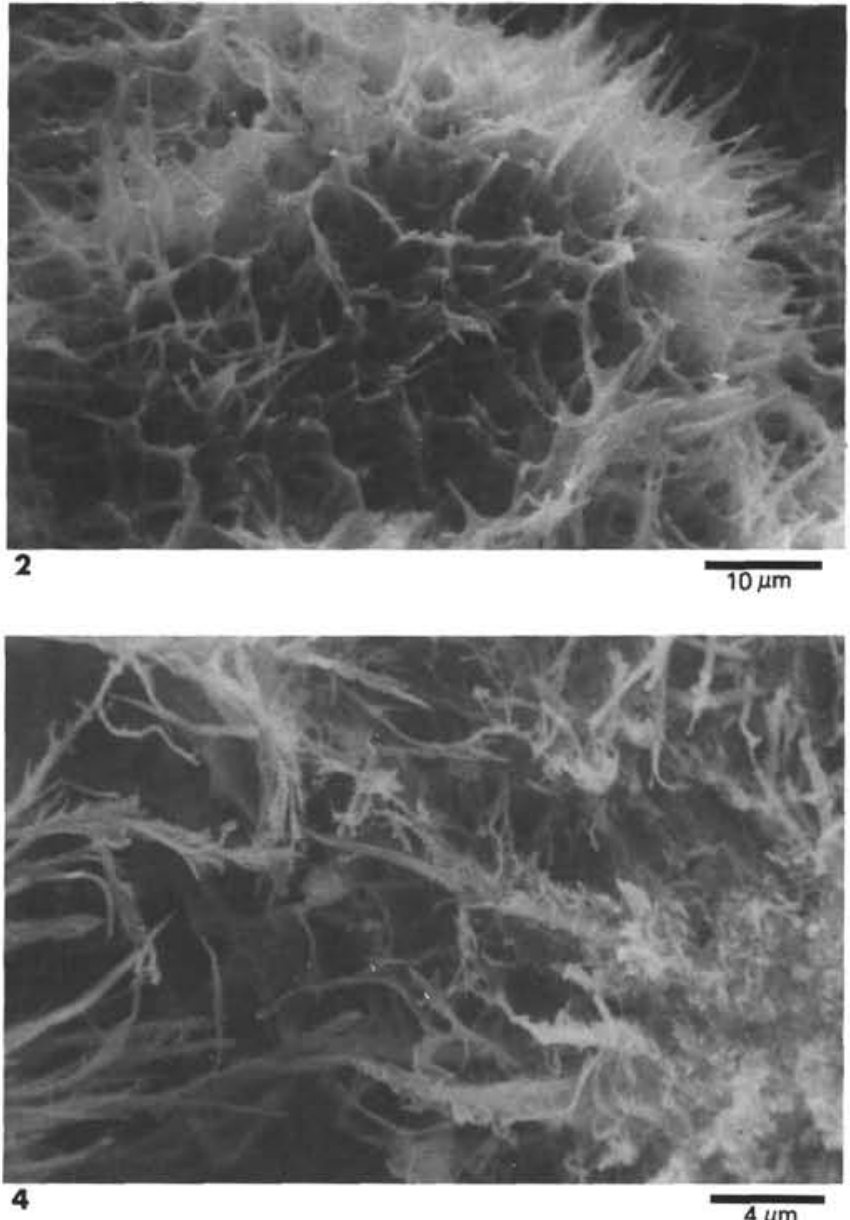

$4 \mu \mathrm{m}$

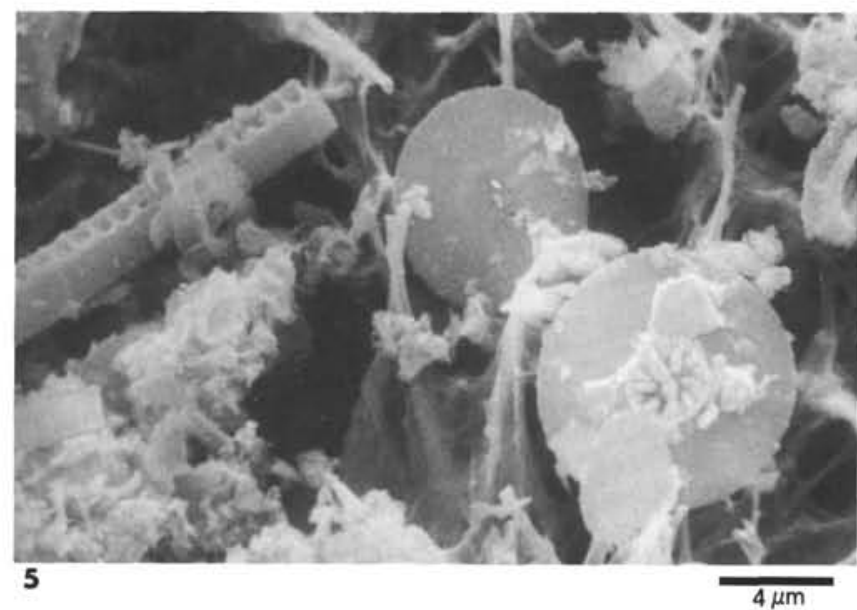

Plate 3. Scanning electron microscope photomicrographs of fragments of crust-like accumulations of manganese hydroxides, predominantly in the form of todorokite (buserite), Sample 509B-3-1, 58-60 cm. 1-2. Increased magnification shows a section of globular structure with development of acicular-fibrous crystals on the globular surface. 3-4. Increased magnification shows aggregates of acicular-fibrous crystal of todorokite (buserite) filling a cavity in the groundmass. 5. Remains of diatoms and coccoliths in a groundmass of manganese hydroxides, partially crystallized into fibrous-acicular crystallites of todorokite (buserite). 


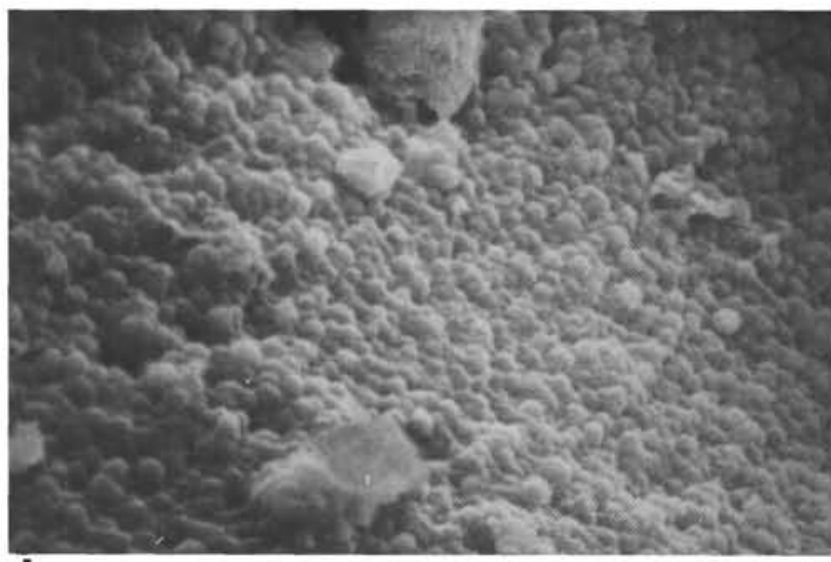

1

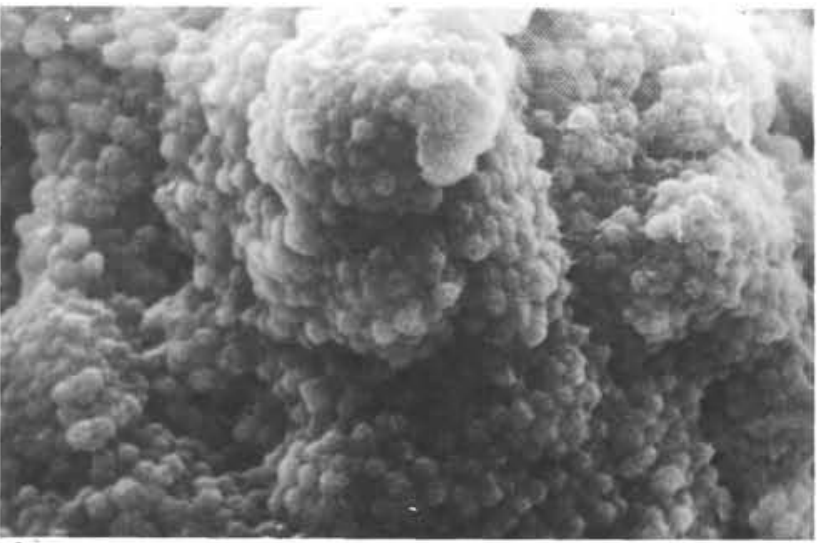

$10 \mu \mathrm{m}$

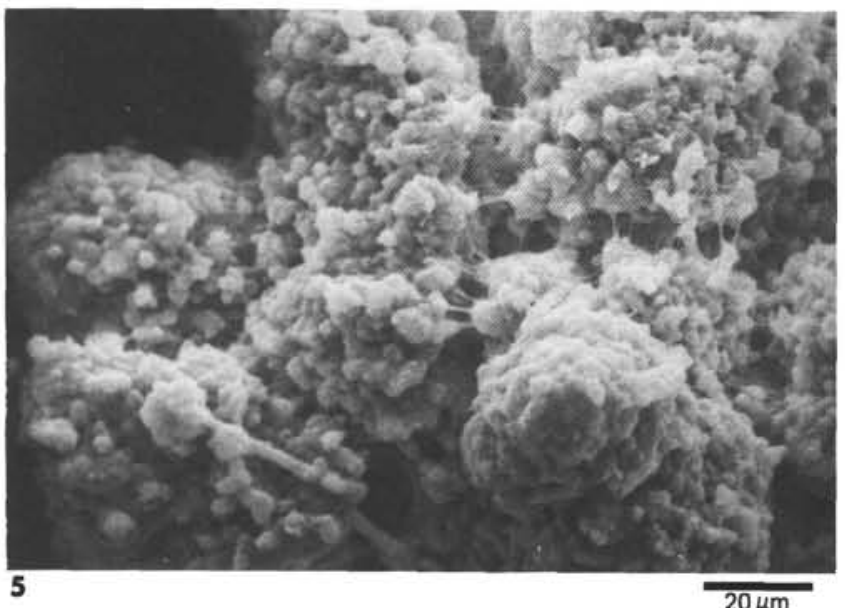

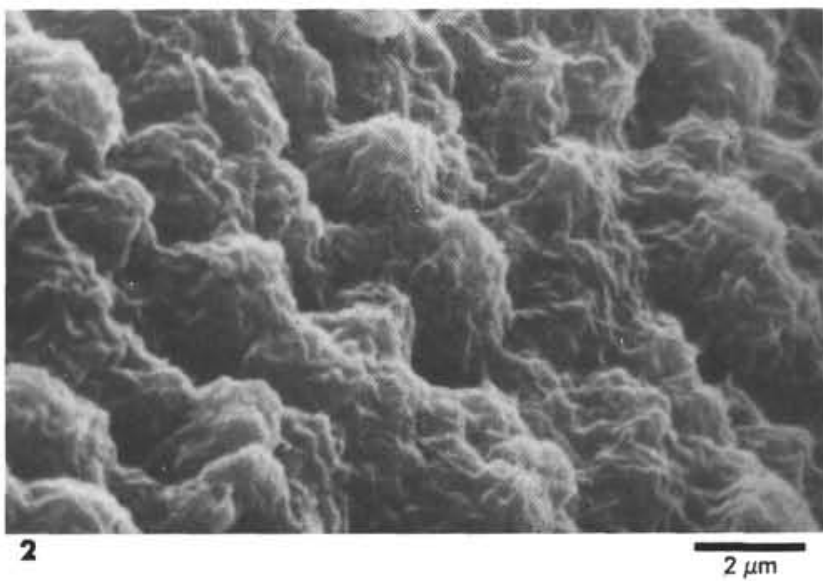
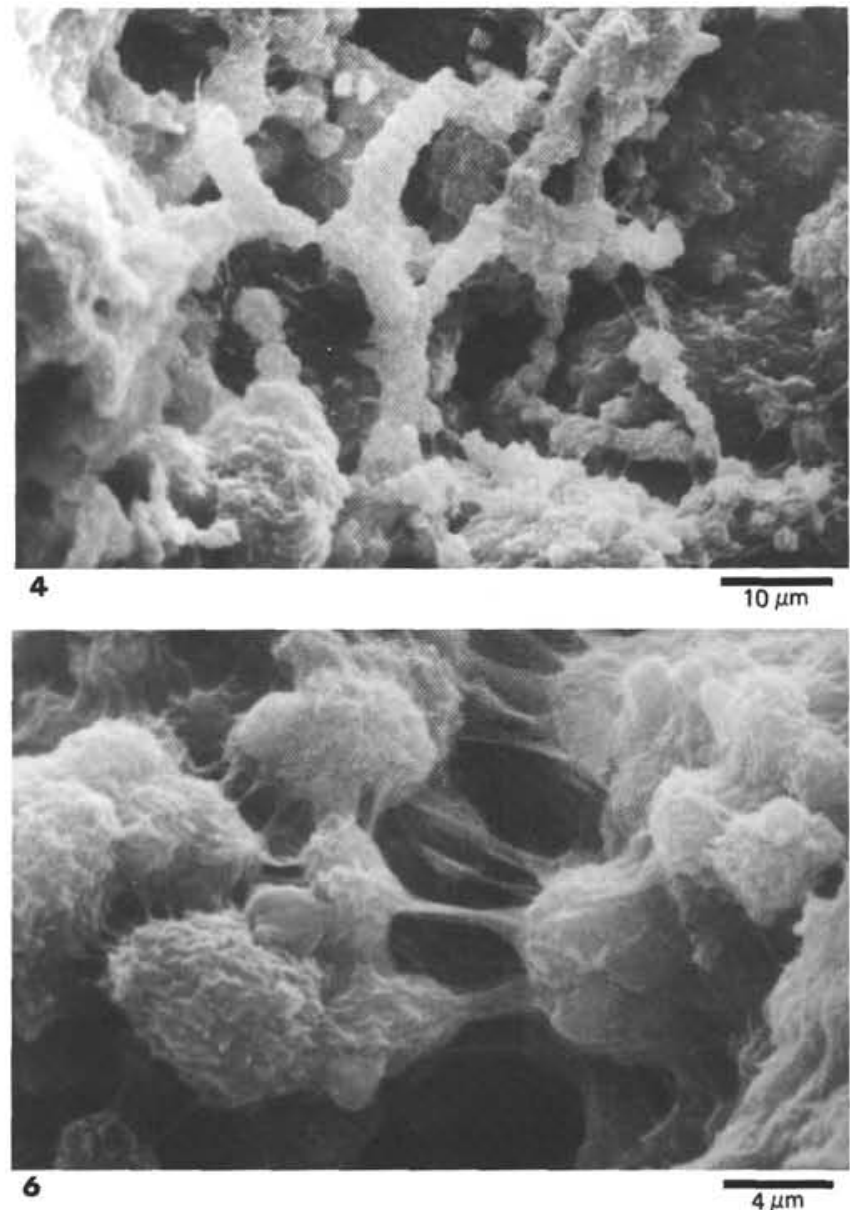

Plate 4. Scanning electron microscope photomicrographs of green hydrothermal clay, showing mixed-layered phases of celadonite and nontronite. 1-4. Sample 509B-4-3, 18-20 cm. (1-2) Increased magnification distinctly shows globular texture with traces of microlayered composition of single globules. (3) Botryoidal aggregates with globular texture. 4. Fragment of globular texture with distinct fibrous intergrowths of globules. 5-6. Sample 509B-4-1, 103-105 cm; botryoidal aggregates with globular texture and distinct, newly formed fibrous crystallites of celadonite. 


\section{M. VARENTSOV ET AL.}
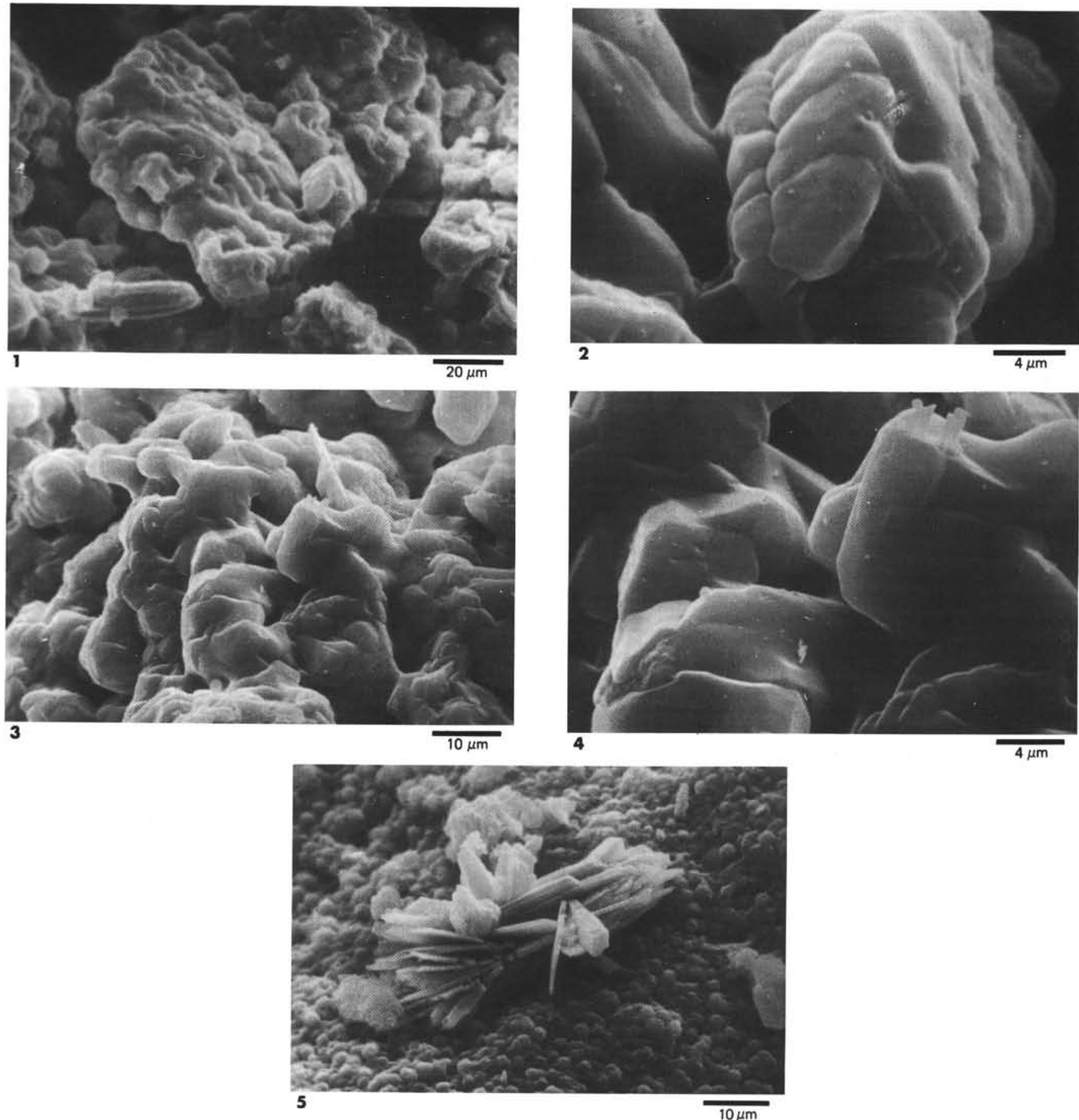

Plate 5. Scanning electron microscope photomicrographs of green hydrothermal clay, showing mixed-layer phases of celadonite and nontronite, Sample 509B-4-3, 18-20 cm. 1-2. Increased magnification shows aggregates with indistinct layers and globular structure. 3-4. Increased magnification shows aggregates with layered, globular structure and distinct microlamination. 5. Druse of phillipsite in globular clayey groundmass. 

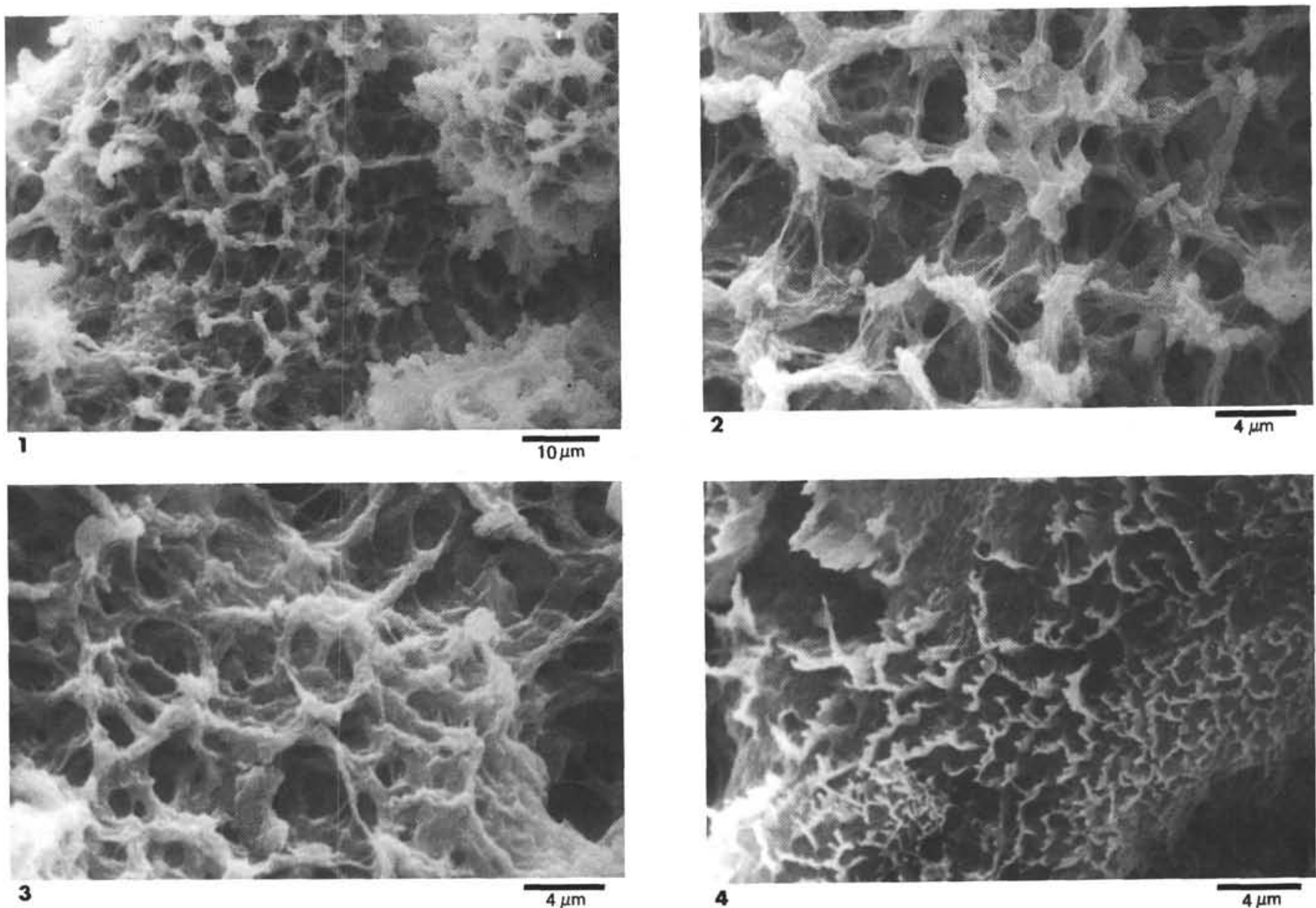

Plate 6. Scanning electron microscope photomicrographs of green hydrothermal clay, showing mixed-layer phases of celadonite and nontronite. 1-3. Sample 509B-4-1, 103-105 cm, (1-2) increasing magnification distinctly shows recrystallization of globular deposits into acicular-fibrous crystallites of celadonite, (3) newly formed fibrous crystallites in globular groundmass. 4. Sample 509B-4-3, 18-20, Recrystallization of globular groundmass into fibrous, scaly aggregates with celadonite. 

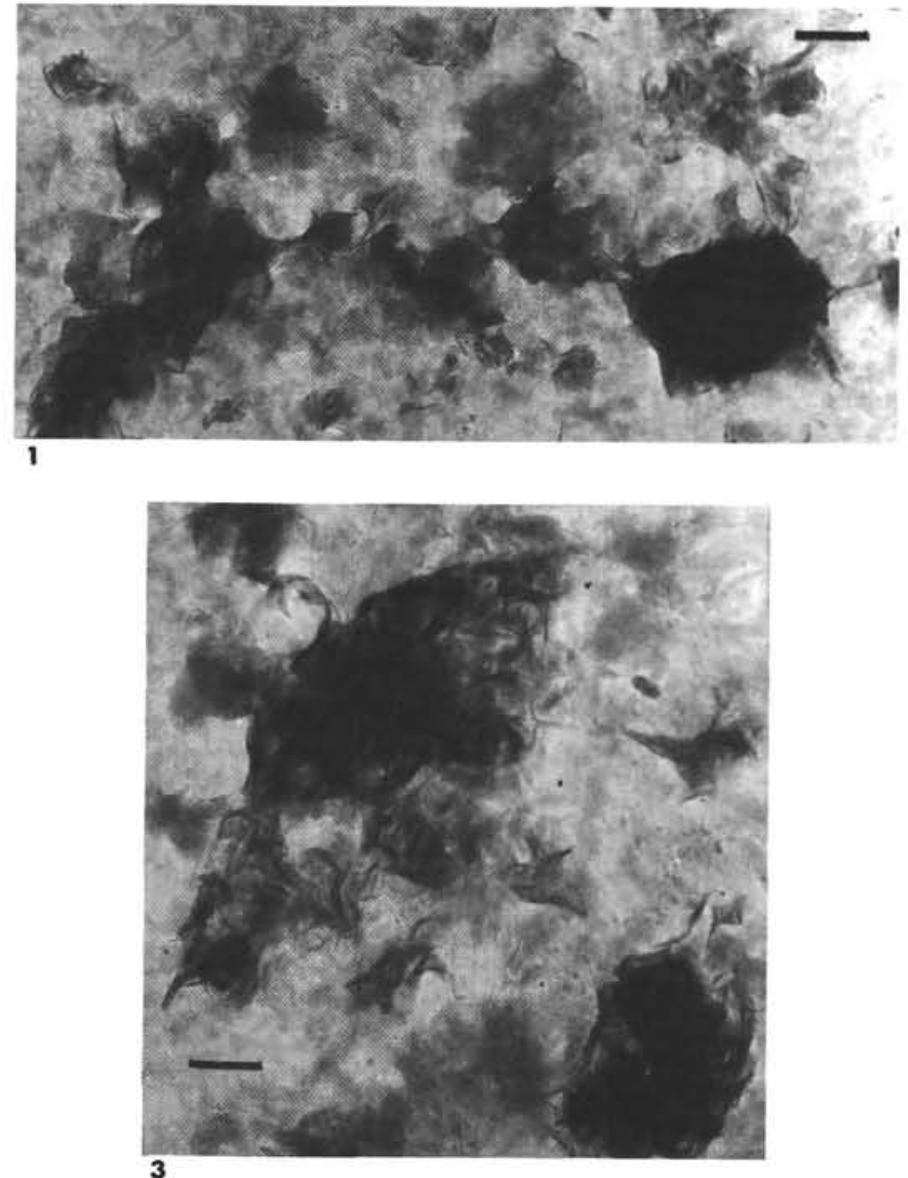

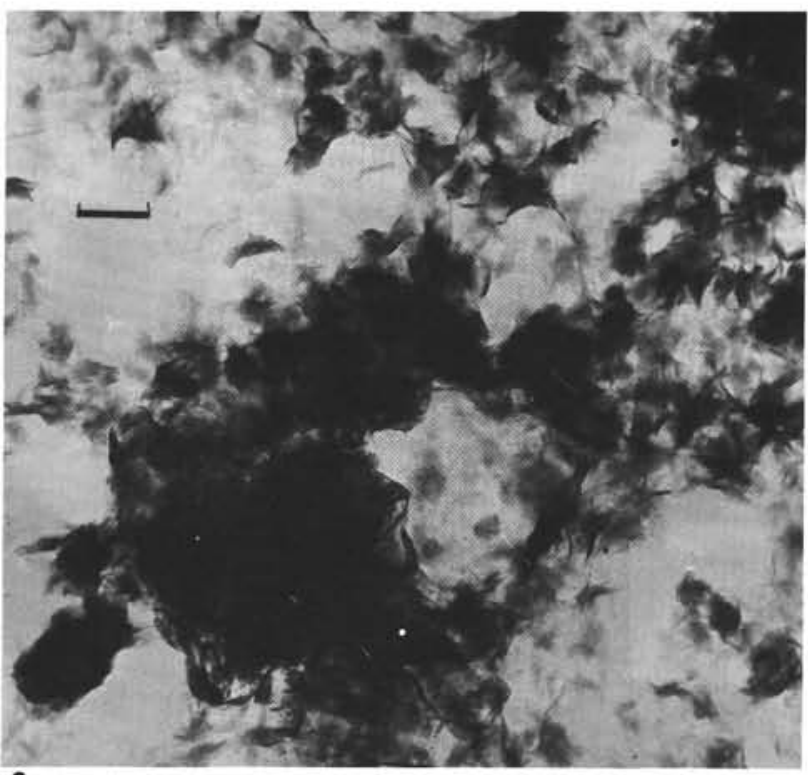

2

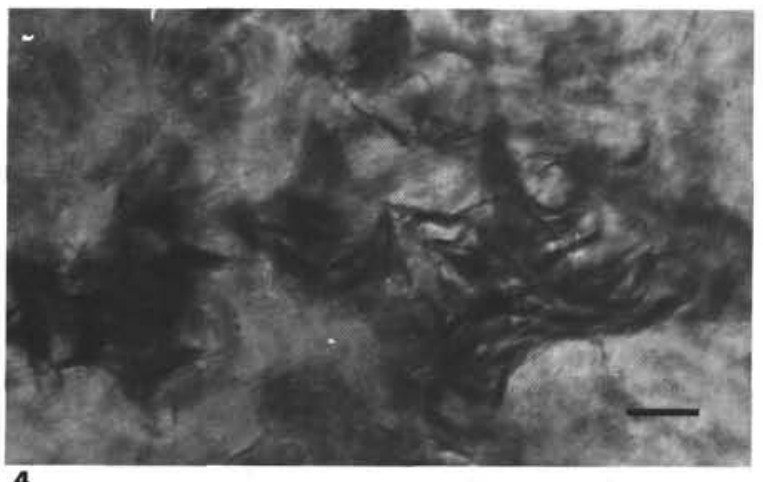

Plate 7. Photomicrographs of green hydrothermal clays taken by transmission electron microscope. 1. Aggregates of particles, represented by a mixed-layer phase of Fe-mica (celadonite) and Fe-smectite (nontronite). Distinct fibrous crystallites of Fe-mica, developing round periphery of relatively coarse particles. Sample 509B-2-2, $57-59 \mathrm{~cm}$. Scale $=0.6 \mu \mathrm{m} .2$. Aggregates of scaly clay particles, represented by mixed-layer phase of celadonite and nontronite. Sample 509B-4-2, 23-25 cm. Scale $=0.6 \mu \mathrm{m}$. 3. Fibrous-scaly aggregates of celadonite, developed round periphery of the particles, represented by mixed-layer phase of celadonite and nontronite $(80: 20)$. Sample $509 \mathrm{~B}-4-3,18-20 \mathrm{~cm}$. Scale 0.5 $\mu \mathrm{m}$. 4. Aggregate of fibrous crystallites of celadonite, developed after particles, represented by a mixed-layer phase of celadonite and nontronite $(80: 20)$; Scale $=0.35 \mu \mathrm{m}$. 